


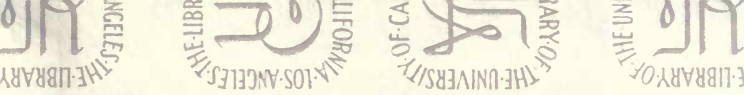

OS ANCELES.

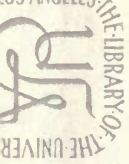

OS.ANGELES.

IIBRARYOOF.

Y]NINA JHI

0 空

3

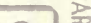

$30\left(\frac{3}{0}\right.$

$\sqrt{0} \frac{\sum}{\sum_{0}^{\frac{1}{2}}}$

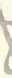

$0:\{1 T+10 \cdot 5$
CALIFORN,

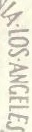

NHE-UIBRARYOF NHE-LIBRARY OF
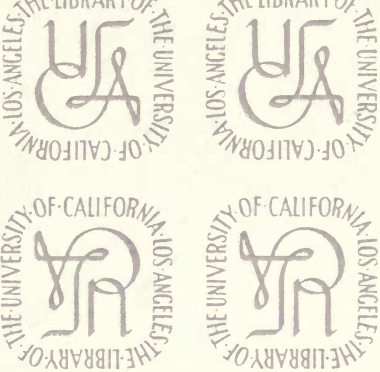

SHE.UNIVERS

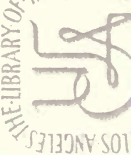

THE UNIVERS/T)
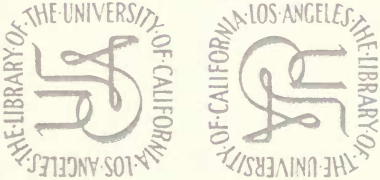

X.NEE LNIVERSIT)

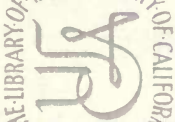

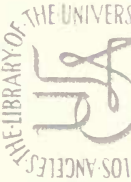

KHELIBRARY

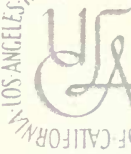

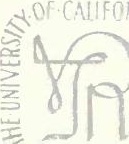




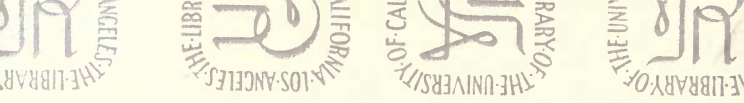

$\underbrace{\text { SANGELES }}_{0}$

3) NNIFHC?

$\underbrace{\text { SANCELES. }}_{0}$

$\exists \wedge|N| 13 H \perp^{\circ}$

IBRARYOF.

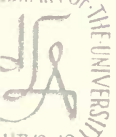

[ITV] $10 \cdot+\frac{1}{2}$

CALIFORN/\%.

葟

MEELIBRARYOF SHELIBRARYOF.
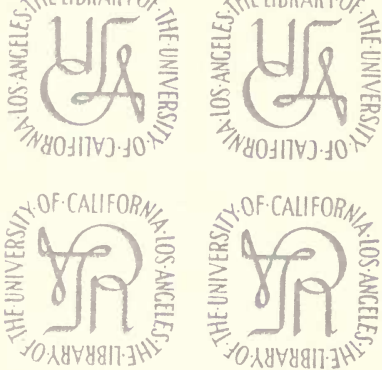

THE.UNIVERSIT) W.LOS.ANGELES.

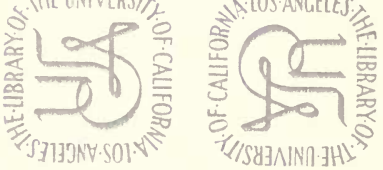

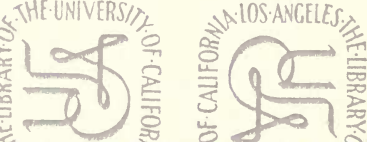

KHE.UNIVERS,

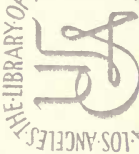

THE.UNIVERS,

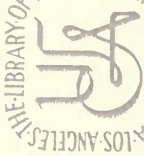

ME.LIBRARYO

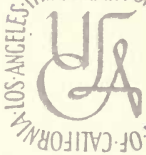



BRITISH QUADRUPEDS. 




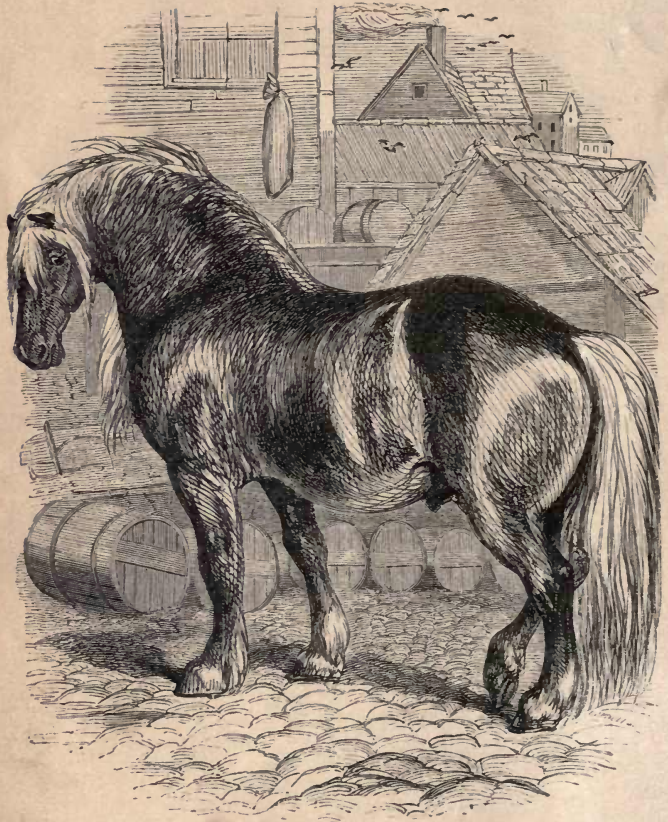

THE DRAUGHT HORSE. 


\section{BRITISH QUADRUPEDS.}

"The heart is hard in nature, and unfit

For human fellowship, as being void

Of sympathy, and therefore dead alike

To love and friendship both, that is not pleased

With sight of animals enjoying life,

Nor feels their happiness augments his own."

COWPER.

SECOND EDITION.

\section{O N D O N : \\ THE RELIGIOUS TRACT SOCIETY;}

Instituted 1799.

SOLD AT THE DEPOSITORY, 56, PATERNOSTER ROW, AND 65, ST. PAUL'S CHURCHYARD. 



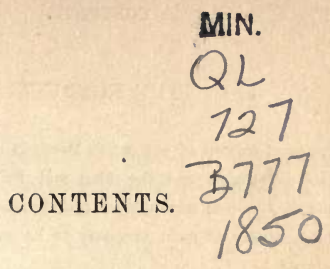

\section{THE STAG, OR RED DEER.}

Remarkable production of the Stag's horns-Their great strength-The number of their ramifications more numerous formerly-The strength of the Stag varies with different seasons-The chase in early timesTreatment of Forest Deer-Their courage and strength when pursuedInfluence of music on these animals-Four Stags driven in a phaeton instead of horses-Their capacity of instruction-Parental feeling of the hind .

\section{THE FALLOW DEER.}

Growth of the horns of these animals-The merciful adaptation of these creatures to their circumstances-Singular provision of two breathing places at the corner of each eye-Tame state of Fallow Deer-Extensive forests or chases once allotted to them-Ingenuity sometimes discovered in obtaining food 


\section{THE ROEBUCK.}

One of the most elegant of our native Deer-It abounds in ScotlandDifference between it and the Stag and Fallow Deer-Its life is shortened by domestic servitude-A considerable range, air, an exercise, and a variety of food, necessary to its welfare-Singular cry of these animals.

\section{THE SHEEP.}

Early mention of this animal-Immense flocks in some parts of Palestine-Simplicity of Sheep husbandry-Names given to Sheep-The Shepherd's horn or pipe-Britain long possessed of Sheep-Variety of breeds-Strength of the principle of imitation-Intelligence of Sheep -Their foresight of storms-Attachment of wild breeds to the place in which they were bred-Their courage-Strong affection of the Sheep for its young * + .
THE ASS

Wild Ass of the East-The domestic kind in that part of the earth far superior to our own-To ride on one in the days of the Judges was no common distinction-Employment of Asses in husbandry-Their use in crossing the deserts of Asia-Their ability for labour-Remarkable journey of one of these animals-Their dulness and stubbornness, the consequence of ill-treatment-Singular sagacity of an Ass-Effect of kindness 


\section{THE FOX.}

Page

Qualities of this animal-Stratagems in pursuit of food-His sagacity in the choice and structure of his abode-Instances of his subtlety in the chase-Failure of his cunning on some occasion
THE HORSE.

Early domestication of this animal-The horses of Arabia-Attachment of their owners to them-Remarkable instances-Use of Horses by the Ancient Britons-The Cavalry Horse-Sublime description in the book of Job-Effects of discipline-Universal Peace to be desired-The Road Horse-Only means of conveyance in former times-Instances of sagacity-The Coach Horse-Slow travelling comparatively recent-Speed of mail and stage coaches-Breaking of Horses-Remarkable power of a rustic-Horses like to be together-Strong attachment between animals of the same species-The Suffolk Punch-The Galloway-Speed and power of these creatures-Amusing stories of some of them-A word for those who cannot plead for themselves . . . . . .

\section{THE CAT.}

The Wild Cat-The Domestic Cat-Value of these creatures in former days and now-“The Raphael of Cats"-Unjustifiable attachment to these animals - Several proofs of their great sagacity-Care for their young-Cats capable of gratitude-Remarkable fact-Singular affection between a Cat and a Dog 


\section{THE SQUIRREL.}

Pleasing appearance of this animal-Its ingenuity as apparent in its nest -Its watchfulness and frugality-Blindness of the instinct of accumulation-The Squirrel may be rendered very familiar-Amusing instance of this-The Squirrel exposed to a considerable change of colour in the northern regions

\section{THE MOLE.}

Commonness of this animal-It exhibits several varieties as to colour-Its structure calculated to awaken admiration-Singular arrangement of its dwelling-Provision made for the winter-Value of Moles to the farmer -Curious instance of the swimming of these animals . . . .

\section{THE OX.}

Man greatly indebted to this creature-Jabal the father of such as have cattle-Who taught man to bend the neck of the Ox to the yoke?State of the Ancient Britons-Parent race of the $0 x-$ Wild cattle at Chillingham - Breeds of cattle now found in our country - Summer pasturing in the Highlands-A mischievous Bull-Watchfulness and honesty of one of these animals-Sympathy displayed by cattle towards others of their kind-Qualities of the Devon Ox-Influence of simple music-Sagacity of the $\mathrm{Ox}$ in South Africa-The Cow-The offering of the red Heifer under the law-Usefulness of the Cow-Anecdotes . 


\section{THE SHREW.}

Page

The Common Shrew - The Water Shrew-Interesting account of its habits

\section{THE BADGER.}

Description of the animal - Its favourite haunts - Its structure fitted for its work-Modes of catching Badgers-When taken young, they may be easily and completely tamed-Strong affection of one of them

\section{THE OTTER.}

Structure of this creature-Its habitation-Superstition in reference to a leader or king of these animals-Otters in the northern parts of Scotland frequent the sea-Dread of them by fishes-An Irish Otter-The Otter may be tamed-Use of one of the Asiatic species-Affection of Otters for their offspring-Pleasing sight in the Zoological Gardens, Regent's Park

\section{THE DOG.}

The canine races probably derived from the Wolf-Story of one belonging to M. F. Cuvier-Reference to the Dog in Scripture-Treatment of this animal in the East-Its noble qualities in favourable circumstances-The Mastiff-Useful for domestic purposes-The Shepherd's Dog-Its great value-Fidelity of one of these creatures-Sagacity of 
another after a snow-storm-Singular service rendered to a child-The thief detected by his Dog-Sin will find out the transgressor-The Bloodhound-An instance of its power-The Pointer-AnecdotesAttachment of a Pointer to a China Goose-The Spaniel-Singular proof of its memory and affection-Story of Dr. Walsh's Dog QuailInstances of strong attachment-The carnage of battle stopped by the sight of a Dog-The Water Dog-Remarkable fact-The TerrierAnecdotes-The Newfoundland Dog-Deliverance from drowning and fire by this animal-The power of one variously displayed-An intem. perate man rescued from death by means of his
THE GOAT.

Its peculiar qualities-The Goats of Switzerland-These animals the leaders of large flocks of Sheep from the plains of Arles towards the Alps-Strong attachment of a Goat .
THE BAT.

Admirable adaptation of the Bat for flight-Various uses of the flying membrane-Analogies in other animals-Habits of the Bat-The longeared Bat-The Barbastelle-Unwarrantable prejudice against these creatures .

\section{THE HEDGEHOG.}

Uncommon mode of defence-Wanton assaults on the Hedgehog condemned-Account of one-Familiarity of others 


\section{THE POLECAT.}

Page

Destructiveness of this species-The fondness of the Polecat for Frogs and Eels .

\section{THE WEAZEL.}

Great antipathy of this animal to Rats and Mice- Its tenacity as to its prey-The ingenuity of an inferior enemy may outmatch violence and rapine-A man attacked by a colony of Weazels-The Weazel may be domesticated-Account of one kept by a lady . . . . . .

\section{THE STOAT.}

Benevolence of God in special provision for his creatures-Change in the covering of the Stoat-The end designed by it
THE FERRET.

Its antipathy to Rabbits-Mode of using Ferrets-Instance of singular ferocity . . . . .
THE MARTEN.

This animal is distinguished by its structure from the Weazel-The Common and the Pine Marten-Anecdotes-Value of the Marten's fur . 


\section{THE HOG.}

Use of the Hog in Minorea and Italy-The Swineherd and his colony in the New Forest-Value of the Pig to the cottager-It readily adapts itself to change-Its sympathy with its kind-Sagacity of several of these creatures-The Pig capable of attachment to man-Abundance of these animals in one of the South Sea Islands-
THE RABBIT.

This animal differs from the Hare-Care of the Rabbit for her youngDeference of a family of Rabbits for their first ancestor-Courage of these creatures - Their value for food and for fur . . . . . 213

\section{THE HARE.}

Enemies of this animal-It is capable of domestication-Cowper's account of Puss, Tiney, and Bess-The Alpine Hare . . . . . . 218

\section{THE DORMOUSE.}

Habits of this animal-Account of one of them . . . . . 228

\section{THE MOUSE.}

Strange repugnance to this delicate little creature-It is sometimes formidable from numbers-Ingenuity of a Mouse-Another devoid of fear from a Cat-Sensibility of Mlice to music-Aneedotes . . . . 231 


\section{THE HARVEST MOUSE.}

Page

The smallest of British quadrupeds-Structure of its nest-Taming of one of them

\section{THE RAT.}

The black and the brown Rat-A Rat may be sociable with other creatures -Austin's cage on the Southwark and Waterloo Bridges-Attachment of animals of different species-Sagacity of a Rat-Conclusion-Limitation of instinct-The faculties of the soul-The great end of life . $\quad .242$ 



\section{LIST OF ENGRAVINGS.}

The Draught Horse.................. Frontispiece.

The Red Deer

The Fallow Deer $\ldots \ldots \ldots \ldots \ldots \ldots \ldots \ldots \ldots \ldots \ldots \ldots \ldots \ldots \ldots \ldots, 10$

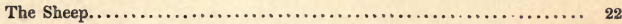

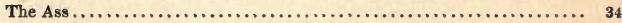

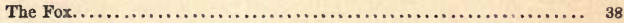

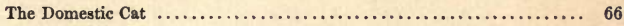

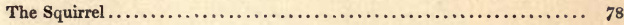

The Chillingham Bull. . . . . . . . . . . . . . . . . . . . . . 92

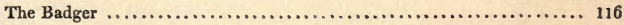

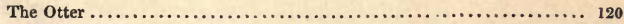

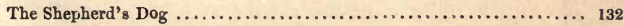

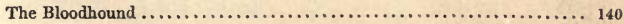




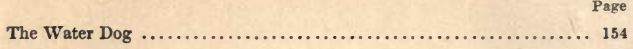

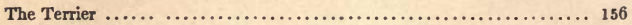

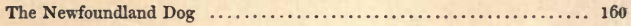

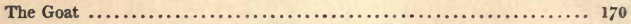

The Bat.......................................... 176

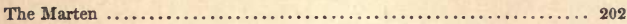

The Hog $\ldots \ldots \ldots \ldots \ldots \ldots \ldots \ldots \ldots \ldots \ldots \ldots \ldots \ldots \ldots \ldots, 204$

The Rabbit $\ldots \ldots \ldots \ldots \ldots \ldots \ldots \ldots \ldots \ldots \ldots \ldots \ldots \ldots \ldots \ldots \ldots \ldots \ldots \ldots \ldots, 214$

The Hare $\ldots \ldots \ldots \ldots \ldots \ldots \ldots \ldots \ldots \ldots \ldots \ldots \ldots \ldots \ldots \ldots \ldots \ldots \ldots \ldots \ldots \ldots, 218$

The Harvest Mouse $\ldots \ldots \ldots \ldots \ldots \ldots \ldots \ldots \ldots \ldots \ldots \ldots \ldots \ldots \ldots \ldots, 236$

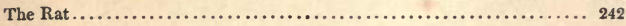




\section{BRITISH QUADRUPEDS.}

\section{THE STAG OR RED DEER.}

THE stag of the European forests is a fine animal, with large branching horns, which are annually lost and re-produced. This process is very remarkable, since a stag's horn, weighing, perhaps, twenty-five pounds, is completely formed in ten weeks. It grows from the outer table of the skull, and has around it a tender soft covering, full of vessels; but when it has acquired its full form and strength, this velvet substance is destroyed in a very curious manner. At the root of the horn, near the skull, a circle of tubercles, called the burr, is found; the principal ressels run between these tubercles, and, as they grow, they close in on the ascending blood-ressels, and prevent 
their conveying blood to the horn; the membrane then becomes insensible and dead, and in time is rubbed off.

The separation of this portion is called fraying; and the huntsman can judge of the size and strength of the stag by the fraying-post, that is, the height of the tree against which he has been butting and rubbing his horns, to separate the outer covering. When this is detached, the horns are perfect.

That the horns are of great strength, is evident from the furious contests in which these animals engage. In one of our museums there are two sets of antlers, entangled and wedged together; they belonged to two stags, which had struck so fiercely against each other, that they could not withdraw their horns, and thus strangely locked together, they were found dead.

It is a curious fact, not generally known, that at one time the horns of stags grew into a much greater number of ramifications than at the present day. There is one in the museum of Hesse Cassel with twenty-eight antlers. Baron Cuvier mentions another with sixty-six, or thirty-three on each horn. It is supposed by some, that the difference arose from the greater abundance of food, and from the animal having 
more repose before population became so dense, and thus living to a greater age.

The strength of the stag varies with different seasons. Sometimes he prefers for food the broom and heath, at others he resorts to copses, springs, and corn-fields; and these changes in his herbage correspond with those in his condition. For a time, he contends with his fellows, but at length strife ceases, and he feeds at peace with his former foes. Now absorption takes place at the root of the horns, and they are shed. Sometimes one is borne a considerable time after the other has fallen; but the oldest and strongest stags shed their antlers the soonest. It is also a remarkable circumstance, that from the absorption at the root of the horn a slight shock will now detach it, though before it could bear the united force of stags when engaged in combat.

One of the most common arocations of the English nobility, in early times, was the hunting of these animals. Among the higher orders of the Anglo-Saxons it was a favourite pursuit; and so fond was the Norman Conqueror William of the chase, that he ordered a large tract of land near Winchester, in Hampshire, to be enclosed, and planted with forest trees. It contained at this period many hamlets, thirty villages, farm- 
houses, and cottages; but their inhabitants were most barbarously turned out, without any recompense; and the New Forest, as it was and is still called, remains, a memorial of William's great injustice and cruelty. Red deer are still found in this place, and in the forest of Martindale, Cumberland, as well as in other parts of England, and also among the mountains of Scotland and Ireland.

The adult stag is from three feet six inches, to four feet high at the shoulders, and the horns seldom reach three feet in length. The male is sometimes called a hart, the female is a hind, the young one is a fawn. The ancients supposed the stag to be very long-lived, but the latest observations allow him scarcely more than twenty years, which is probably less than his average life in those countries where he can feed and range undisturbed by man. Yet even now, in some of the deer-forests of Scotland, the stag occasionally attains a great age. Mr. Scrope mentions some well-attested instances in recent times, of deer, which it was ascertained were more than a hundred years old.

Forest deer, though pasturing at large, seldom stray far from their walk; and the keeper, who wishes them not to wander, encourages them to stay at home, by giving them in summer the spray of ash, and in winter, 


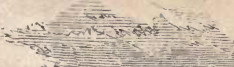

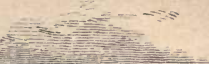

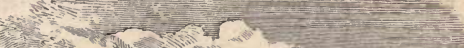

\section{3 s.}

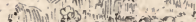

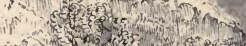

If

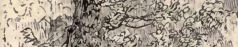

is
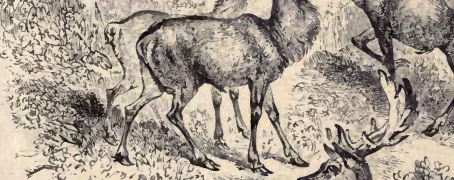

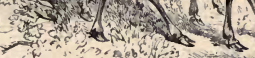

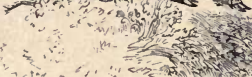

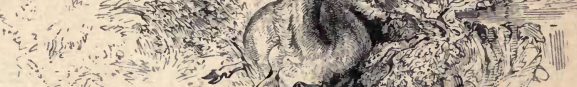

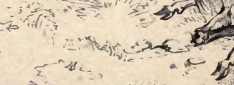

$$
\begin{aligned}
& \text { aym } x
\end{aligned}
$$

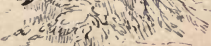




$$
\bullet
$$

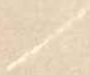

5 
holly and other plants, of which they are fond. As he comes forth to bestow his favours, he makes a noise, which in calm summer evenings may be heard resounding through the woods, to call his scattered family together.

Retiring in the day to the shelter of the woods, they feed generally at night, or in the morning; reminding us of the poet's words :-

"The day pours in apace,

And opens all the lawny prospect wide;

The hazy woods, the mountain's misty top,

Swell in the sight; while o'er the forest glade

The wild deer trip; and often turning, gaze

At early passengers."

Men without guns, horses, or carriages, excite the curiosity of the stag more than his fears. In passing through a forest in August or September, however, if we see one of these animals at a distance, it will be best to avoid him, by turning to the right or left. If we do not approach, he will not pursue. The oldest foresters, it is said, do not remember an instance of voluntary mischief done at any time by a stag. He is soon sensible, however, of the advance of foes.

" The antlered monarch of the waste Sprung from his heathery couch in haste ; 
But, ere his fleet career he took,

The dew-drops from his flanks he shook;

Like crested leader proud and high,

Tossed his beamed frontlet to the sky;

A moment gazed, and down the dale

A moment snuffed the tainted gale;

A moment listened to the cry,

That thickened as the chase drew nigh;

Then, as the headmost foes appeared,

With one brave bound the copse he cleared."

Thus pursued, he will not stop to resist the dogs, or stand at bay, until he is exhausted, or driven to the water. With all his senses very acute, his courage is determined; even at the last, he is sometimes capable of amazing effort. In the New Forest there is a celebrated spot, called the Deer-leap, where a stag was once shot, and in the agony of death, collecting all his strength, he gave a bound, which astonished all who saw it. It is marked out by two posts, fixed at the extremities of the leap, and the space between them is something more than fifty-four feet !

The stag, it appears, like some other creatures, feels the influence of music. Playford tells us, that as he once travelled near Royston, he met a herd of these animals, amounting to about twenty, following a bagpipe and violin on the road; while the music played, they went forward, when it ceased, they all stood still, 
THE STAG.

and in this manner they were brought out of Yorkshire to Hampton Court.

The late Lord Oxford did many eccentric things, and among them was his driving four red-deer stags in a phaeton, instead of horses. These he reduced to perfect discipline, for his excursions and short journeys on the road. Unhappily for him, however, on one occasion, the ears of his singular steeds were saluted by the cry of a pack of hounds, which soon after crossing the road in the rear, caught scent of them, and commenced a new kind of pursuit. In vain did his lordship exert all his charioteering skill, and his grooms endeavour to ride before the stags; reins, trammels, and the weight of the carriage were of no effect, for they went with amazing swiftness. They had often been driven before to the Ram Inn, at Newmarket, and it was well for them and their driver, that this was now at hand. Into the yard they suddenly bounded, to the great consternation of all the persons it contained. Here they were overpowered, and the stags, the phaeton, and his lordship, were instantaneously huddled together in a barn, just as the hounds appeared in full cry at the gate. We conclude that his lordship did not again expose himself to a similar chase.

Delacroix leads us to suppose that the stag is capable 
of much instruction. "When I was at Compeigne," he says, "my friends took me to a German, who exhibited a wonderful stag. As soon as we had taken our seats in a large room, he was introduced. The stag was of an elegant form and majestic structure, his aspect at once animated and gentle. He first made a profound obeisance to the company as he entered, by bowing his head; after which he paid his respects to each individual of us in the same manner. He next carried about a small stick in his mouth, to each end of which a small taper was attached. He was then blindfolded, and, at the beat of a drum, fell upon his knees, and laid his head on the ground. When the word pardon was pronounced, he instantly sprung upon his feet. Dice were thrown on the head of a drum, and he told the numbers that were cast up by bowing his head so many times. He discharged a pistol, by drawing with his teeth a string that was tied to the trigger. He fired a small cannon by means of a match that was fastened to his right foot, without showing any signs of fear. $\mathrm{He}$ leaped several times, with the greatest agility, through a hoop, which his master held at a man's height from the ground. At length, the exhibition was closed by his eating a handful of oats from the head of a drum, which a person was beating the whole time with the utmost 
violence. Almost everything was done with as much steadiness, as it could have been accomplished by the best trained dog."

The hind displays fully the parental feeling. Often has she been found to suffer all the terrors of the chase, in order to draw off the dogs from the hiding-place of her offspring. She is exceedingly bold in their defence, exhibiting the most determined courage, and frequently obliging the dog, and even the wolf, to give way. 


\section{THE FALLOW DEER.}

This animal is inferior in size to the common stag, and may be seen in parks throughout England. The male is horned; it is called a buck, the female a doe, and the young one a fawn.

The first year, no horns are to be seen on the fawn; the second, when it is styled a pricket, the horns are simple dags, or processes; the third, two branches appear, and the palms begin to be visible; but it is the fifth year before the animal is considered "a buck of the first head ;" after this time the horns only increase in volume.

The head of these animals is furnished with two breathing places besides the nostrils. When thirsty, they plunge their noses very deep under water, and continue them there while drinking a considerable time. But, to prevent inconvenience, they open these two vents, one at the inner corner of each eye. These communicate with the nose, and doubtless afford the deer a more free respiration when running very swiftly; so 


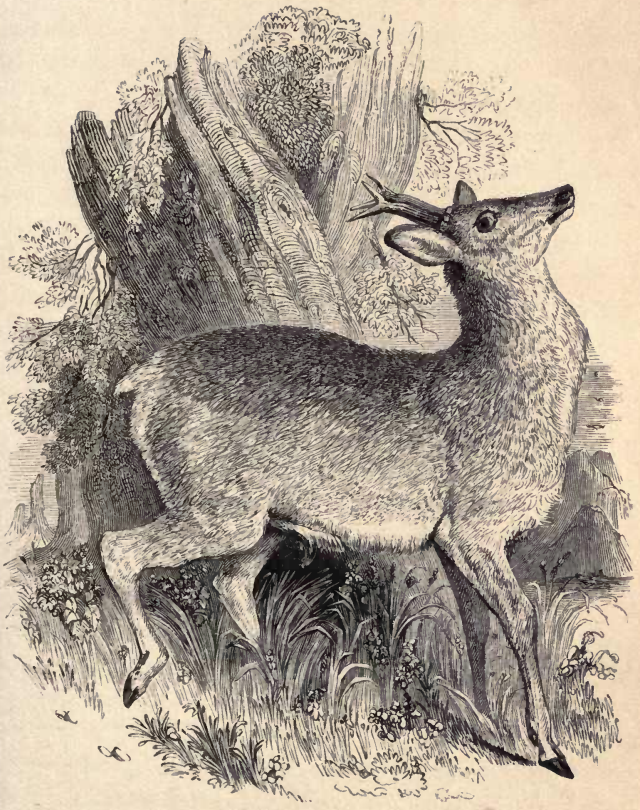

THE FALLOW DEER. 


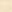


mercifully does the great Creator adapt his creatures to their various circumstances.

The common fallow deer is generally to be met with in a tame state. There are a few places where the enclosures have in the course of time been broken down, where they run at large, without food or shelter in winter; and from thence they have occasionally strayed into such neighbouring parts as are wild, extensive, and wooded. On the continent, as in England, they are generally kept in parks. In former times they were royal property; extensive forests or chases were allotted to them alone, and property of all kinds was disregarded, to provide for their support and pursuit. As civilization and agriculture advanced, their bounds were curtailed, and, as always happens, the wild animals gave way to culture.

These creatures are gregarious; and in parks the herd sometimes divides, and repeated battles ensue for the possession of a favourite spot. They prefer elevated countries and hills. When hunted, they do not flee in a direct line, but in a circle, and take to the water, but without venturing, as the stag does, to swim broad rivers. As an article of food, their venison, at least in England, is far superior to that of other deer. Besides the spotted variety, there is one of a dark brown colour, 
the fawns of which have not even the spots so common to most others. It is reputed to have been introduced by James the First, from Norway.

Ingenuity is sometimes discovered by these animals. The berries on the thorn-trees are often beyond reach, yet some of the old bucks in Bushy Park have been observed to obtain them by simple yet effective means. They raise themselves on their hind legs, give a spring, entangle their horns in the lower branches of the trees, shake them once or twice, thus causing some of the berries to fall, and then they very quietly pick them up. 


\section{THE ROEBUCK.}

THE common roebuck is one of the most elegant of our native deer, and appears as a beautiful and appropriate object in the woods and copses of the Scotch highlands. In Scotland, north of the Firth, it is everywhere abundant, where rocks and trees abound; so much so, indeed, that in some places these animals are doomed to death from the damage they do to the young wood. The roebuck leaves places of sterner character to be frequented by the red deer, delighting in the lower coverts, and in scenes less solitary and wild. It differs from the fallow deer in having round horns; from the stag, in the smallness of its size, and the proportionable smallness of its antlers; and from every animal of the goat kind, in annually shedding its horns.

The roebuck grows faster than the stag, and his life is shorter. It seldom continues more than twelve or fifteen years; and if in a state of domestic servitude, it is diminished to seven or eight. As the constitution of this animal is delicate, he requires a considerable range, 
and a variety of food, as well as air and exercise. $\mathrm{He}$ can be easily subdued, but never perfectly tamed. He will scent a man a long way off, and hold his nose in the air, like a pointer drawing on his game. The cry of these creatures resembles the baa of a sheep, but it sounds somewhat like a bark. At night especially, and in still moonlight, it may be heard to a great distance, and roebucks are constantly answering each other through nearly a whole night. 


\section{THE SHEEP.}

Mention is made of this animal shortly after the expulsion of Adam from Paradise. "Cain," it is said, "brought of the fruit of the ground an offering unto the Lord; and Abel, he also brought of the firstlings of his flock and of the fat thereof." Gen. iv. 3, 4. Thus the latter, in the exercise of faith, presented the appointed type of "the Lamb of God, which taketh away the sins of the world," and through whom alone all who believe in him, from the days of the patriarchs to the end of time, shall be saved.

So numerous were the sheep as well as cattle of Abraham and Lot, that there was not sufficient pasture for their united possessions. The Scriptures often speak of the immense flocks of sheep with which some parts of Palestine abounded. They were, in patriarchal times, the chief riches of the people. Sheep husbandry was then exceedingly simple. It consisted in a constant change of pasture, so far as it could be arranged, towards the north from winter to summer, and towards 
the south from summer to winter; and also, in contriving to encamp for a time near some rivulet or well, whence water might be readily obtained.

In keeping with the accounts of profane authors some centuries afterwards, when the daughters of nobles and princes are described as employed at home in weaving garments for the household, or attending the sheep, the driving of the flocks to and from the water, was the business of the female part of the family; to which was sometimes added, their oversight during the day, that they might not stray too far from the tents. The shepherd, however, who was either the head of the family, his son, or some confidential servant, was at hand in cases of difficulty and danger; and when night came on, the sheep were driven to the immediate neighbourhood of the encampment, or enclosed in a fold, where he lay down in the midst of them, either in a temporary hut, or exposed to severe cold. Jacob alludes to his sufferings in such circumstances, when he says, "In the day the drought consumed me, and the frost by night ; and my sleep departed from mine eyes ;" words, which may well suggest to us the pains and sorrows of Him, who is the great Shepherd of Israel, and who laid down his life for his sheep.

In a wild and boundless desert, and without such a 
helper as the intelligent and faithful dog of a modern shepherd, it was necessary that one of ancient times should have command over them; and this he acquired by being always among them, and by kindness of treatment. Referring to his travels in Greece, Mr. Hartley says, "I asked my man if it was customary to give names to sheep. He informed me that it was, and that the sheep obeyed the shepherd when he called them by name. This morning I had the opportunity of verifying his statement. Passing a flock of sheep, I asked the shepherd the same question that I had put to my servant, and he gave me the same answer. I then bade him to call one of his sheep. He did so, and it instantly left its pasture and its companions, and ran up to the hands of the shepherd with signs of pleasure, and a prompt obedience, which I had never seen excelled in any other animal. He told me, also, that many of his sheep were still 'wild,'- that they had not yet learned their names,- - but that, by teaching, they would all learn them. The others, which knew their names, he called 'tame."'

It is said that Jesus "calls his own sheep by name," and that "they know his voice." The multitude, alas ! heed it not; they go on, loving sin and practising iniquity, as if he preserved a constant silence ; but it is not 
so with those who are the special objects of his love and care. $\mathrm{He}$ calls them away from the vanities of the world, from sinful pleasures, from trust in man, and from dependence on themselves, and they obey his word. He invites them to "the green pastures" of his service and ordinances; and availing themselves of the proffered privilege, they give proof that they know his voice. May the language of every reader be :-

" Thy flock, with what a tender care,

Bless'd Jesus, dost thou keep !

Fain would my weak, my wandering soul

Be number'd with thy sheep.

Gentle, and tractable, and plain,

My heart would ever be,

Averse to harm, propense to help;

And faithful unto thee.

The gentle accents of thy voice

My listening soul would hear;

And by the signals of thy will

Direct my whole career."

Various breeds of sheep are described by early writers on agriculture, as existing in Spain; they were of different colours, black, red, and tawny; and probably imported from Italy. They were of a breed which had gradually spread from the coast of Syria and the Black 
Sea, and had now reached the western extremity of Europe. Some of them continued to exist as a distinct race, and were the ancestors of the merinoes of the present day. These wander not, like others, from the district or the property on which they are bred, and amount to about two millions.

As the pastures in ancient times consisted of immense plains, or of abrupt alternations of hill and dale, with many a tangled copse and forest, so that the sheep were sometimes beyond the sight of the keeper, and even his voice, he had a horn or pipe, the sounds of which the leaders of the flock instantly obeyed. The same means have been used in later days. Goldsmith says, "Before I had seen the sheep trained in this manner, I had no conception of those descriptions in the old pastoral poets, of the shepherd leading his flock from one country to another. As I had been used to see these harmless creatures driven before their keepers, I supposed that all the rest was pure invention; but in many parts of the Alps, and even in some provinces of France, the shepherd and his pipe are continued with true antique simplicity. The flock is regularly penned every evening, to preserve them from the wolf; and the shepherd returns homeward at sunset, with his sheep following him, and seemingly pleased with the sound 
of the pipe, which is blown with a reed, and resembles the chanter of a bagpipe."

Britain has been for many ages possessed of sheep, which were probably indigenous to our country. Cæsar describes the habits and manner of life of its early inhabitants very circumstantially, but makes no mention of these interesting animals, or the employment of its wool for clothing; and hence it has been supposed, that the use of this material was little, if at all, known to the Britons, who when clothed were usually dressed in skins. But at that period the Gauls had the art of making a kind of cloth or felt, without spinning or weaving, sufficiently strong to resist the stroke of a sword; and from them some of our southern tribes were supplied with woollen garments.

Engaged in war, the Britons painted their bodies to terrify their foes; but at peace at home, they were clothed with the skins of beasts, and lived on milk and flesh. Milk was one of the earliest articles of food in every ancient and uncivilised tribe ; and the use of the milk of sheep preceded, by many centuries, that obtained from cattle, in all these hordes. It is probable, therefore, that sheep existed in this island, in early times, in that state of domestication in which they were found among other nations, long before the subjugation of the ox. 
The breeds of sheep in this country are numerous and various. Some are horned, and others hornless. Of the former, the most ancient is the black-faced, still met with in some heathy parts of Yorkshire, and the adjacent northern counties; the wool is coarse and shaggy. The Norfolk and Suffolk sheep, also, have the horns large and spiral, with the face black, but the wool is short and fine. In the Dorset, the face is no longer black, but both sexes are usually horned; and as this breed is remarkable for producing lambs at almost every season, it is highly valuable for supplying the London markets with house-lamb. The Wiltshire is a much larger variety. The Hertfordshire is a fine productive race, with short tails. The Exmoor, which comes from Devonshire, is small, the wool long, and the face and legs white. Scotland furnishes three breeds of horned sheep, the Dun-faced, the Zetland, and the Hebridean.

There are nine other breeds of the hornless race. The Lincoln has long wool, and a white face. In the Teeswater, the wool is shorter and lighter, and the legs longer ; the Dishley is known by a clean head, and the goodness of its flesh; the Devonshire Nots, like the three preceding, are long-woolled. Others are shortwoolled, as the Hereford; the store sheep of this 
country are called Collings, or Rylands. The South Down, principally found on the chalky downs of Sussex, have the face and legs gray, and are highly esteemed for the table. The fleece of the Cheviot is very short and fine. The Hardwicke, peculiar to the rocky districts of Cumberland, is speckled on the face and legs.

In sheep, the principle of imitation is remarkably strong, and though it is often very difficult to drive a number of them into a narrow lane, yet if one be forced into it, even by violence, the remainder will readily follow. Dr. Anderson gives the following ludicrous example of this :- “A butcher's boy was driving some fat wethers through Liverpool, but they ran down a street along which he did not want them to go. He observed a scavenger at work with his broom, a little way before him, and called out loudly to him to stop the sheep. The man did accordingly what he could, to turn them back, running from side to side, always opposing himself to their passage, and brandishing his broom with great dexterity; but the sheep, much agitated, pressed forward. At last one of them came right up to the man, who, fearing that it was about to jump right over his head while he was stooping, grasped the short broomstick in both hands, and held it over his head. He stood for a few seconds in this 


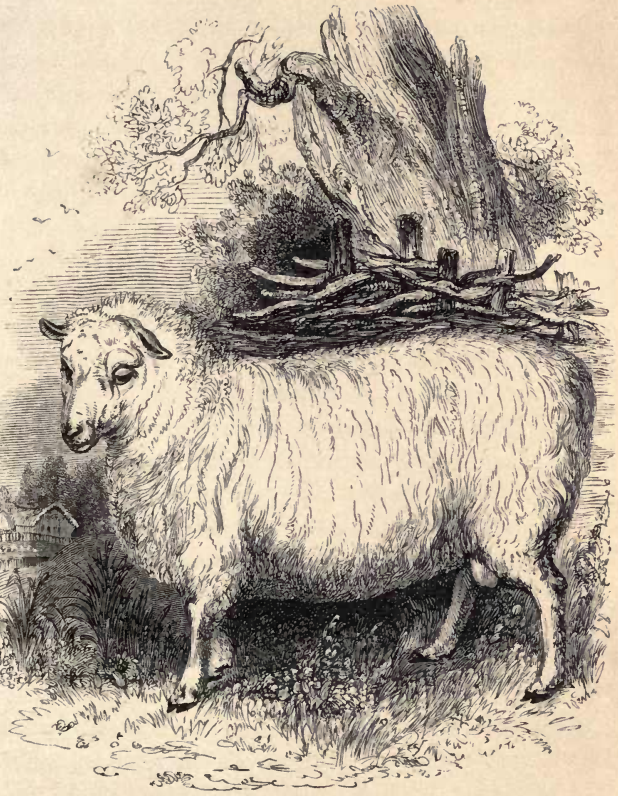

THE SHEEP. 


\section{,}


position, when the sheep made a spring, and jumped fairly over him, without touching the broom. The first had no sooner cleared this impediment, than another followed, and another, in such quick succession, that the man, perfectly confounded, seemed to lose all recollection, and stood in the same attitude till the whole had jumped over him, not one of them attempting to pass on either side, though the street was quite clear."

The sheep is commonly considered an animal of far inferior power to others, as the horse, or the ox, when employed in agriculture ; but it should be remembered, that these animals have much training, while the former is merely driven to and from his pasture, often at the expense of fright and occasional injury. Instances may, however, be easily collected, to show that the sheep is a creature of considerable intelligence. In the mountainous parts of Wales, for instance, where the liberty enjoyed by the sheep is so great as to render them very wild, they do not always collect into large flocks, but sometimes graze in small parties of from eight to twelve, of which one is stationed at a distance from the rest, to give notice of approaching danger. When the sentinel observes any one advancing at the distance of two or three hundred yards, he turns his face to the enemy, keeping a watchful eye on his 
motions, and allowing his approach within a certain distance. But when the suspected foe shows his intention of coming nearer, the careful guard alarms his companions by a loud hiss or whistle, twice or thrice repeated, and the whole party instantly scour away with great agility, always seeking the steepest and most inaccessible parts of the mountains.

In Scotland, dreadful storms sometimes take place, and of the approach of these, sheep have generally an unerring foresight, or rather of the coming wind that will drift ; and they will hurry away to some tried and approved shelter, when the shepherd sees not a cloud, and dreams not of the wind. One of these mountain shepherds says: "I had left my sheep under their accustomed shelter, and where I had never failed to find them safe and comfortable in the morning, and I was plodding my weary way homeward; but before distance and darkness closed them from my sight for the night, I looked back to see if they had ceased to dig for food, for there was snow on the ground, when I was surprised to see them on their march down hill, towards a small plantation, which would afford securer shelter, and to which I had been accustomed to drive them, when I feared the coming tempest. They had fallen into rows, pacing one after the other until they reached the 
THE SHEEP.

plantation; and there was nothing to suggest to my mind the return of a drift, but their movement and their bleating. They passed through the plantation, and took that side of it which would afford them a safe shelter from the south-west hurricanes." In this instance, as in many others, the sheep were right, for a storm soon came.

Nor should it be forgotten, that the wild and aboriginal breeds are strongly attached to the place in which they were bred. This disposition has been shown by Welsh sheep. One of them, having a face streaked like a badger's, was brought up among others into Herefordshire for sale, and bought by a farmer, who soon lost it. It was afterwards proved that it returned home into Wales; it was brought up in a Welsh flock a second time, and returned as before; and on being brought up a third time, it was clearly proved to be the same sheep.

The feeling thus manifest is still more so in the wilder sheep of the black-faced and Highland breeds : it seems indeed to be always a powerful principle with them, but it prevails most at the time of yeaning. Of this, the following is an interesting instance :-A black ewe was missed from the farm of Harehope, in Tweeddale. A shepherd was despatched in pursuit of her, who traced her many a mile, and then abandoned the 
chase. He was told that she was several times stopped, but she absolutely persisted in travelling on, regarding neither sheep nor shepherd by the way. Her lamb was often far behind, and she had often to urge it on by impatient bleating. She arrived at Stirling on the morning of a great annual fair, about the end of May; and judging it imprudent to venture through the crowd with her lamb, she halted on the north side of the town, lying close by the road-side during the whole of the day ; but, next morning, when all became quiet, a little after dawn, she was observed stealing quietly through the town, in apparent terror of the dogs that were prowling about the streets. The last time she was seen on the road, was at a toll-bar. The man stopped her, thinking she was a strayed animal, and that some one would claim her; she tried several times to break through by force when he opened the gate, but he always prevented her, and at length she turned patiently back. She, however, found some means of eluding him, for home she came at last, having been no less than nine days on the road.

Sheep become courageous in proportion as they are withdrawn from the protection and control of man. This appears when they range on extensive mountains of the north, as they do for months together, during 
which they are scarcely seen. A ram will then boldly attack a dog, and generally prove the victor. Should several dogs or foxes appear, the sheep form themselves into a compact body, the males taking the foremost ranks, keeping closely together, and presenting a determined front to the foe, while the females and the young are placed behind. The rams advance in order on their assailants; and when these have come within a certain distance, they rush forward, and generally destroy them.

A traveller in Scotland says: "I was one day climbing the mountain of Belrinnis. On reaching the top, I found myself in a cloud, whence I could not see any object distinctly at the distance of more than a few yards. As there was a fine breeze, I hoped that the cloud would disperse ; and, although I felt exceedingly cold and hungry, I resolved to remain there a little while. While I was walking about to keep myself warm, I perceived something of an uncommon appearance at a little distance from me, and I approached it, not indeed without fear. I found it to be a phalanx of sheep, drawn up at the top of the hill, and ready to defend themselves against attack. They were arranged in a kind of wedge, presenting its blunt end foremost; in the middle of the line was a large ram with a black forehead, and a tremendous pair of thorns; a number of 
weaker ones were in the rear, not one of them eating, but looking sternly at me. I was not at first afraid, knowing them to be only sheep; and yet I was not perfectly easy, for if any fox appeared, they might kill me in chasing him. These sheep had been sent into the mountain in April or May, when the owners seldom look after them till October. When they gather themselves together at night, one of them is always placed at a little distance as a sentinel. They never descend into the valley at night, or rest in any low and sheltered place, but even in the most stormy weather they are on the top of the hill or on rising ground ; and if they are attacked by foxes or dogs, their assailants rarely fail to pay for their temerity with their lives. Seeing them, however, in this warlike array, I began gradually to feel a little alarm, and deeming discretion to be the better part of valour, I slowly retired. As the distance between us increased, their line was neither so straight nor compact; but I-stopped, and again advanced a few steps towards them; they looked steadily at me, and formed their line with greater precision and closeness; and had I attempted to attack them, I am convinced that they would have resisted. I had once a great mind to try, but I confess that my courage failed me when I observed them seemingly bending their 
knees, in order to make one simultaneous rush upon me."

To notice only one other quality of the sheep, it may be remarked, that it discovers a strong affection for its young. According to Hogg, the Ettrick Shepherd, "An interesting provision of nature with regard to these animals is, that the more inhospitable the land is on which they feed, the greater will be their kindness and attention to their lambs. I once herded," he says, "two years on a wild and bare farm, called Willenslee, on the border of Mid Lothian; and of all the sheep I ever saw, these were the kindest, and most affectionate to their young. We had one very bad winter, so that our sheep grew lean in the spring, and disease came among them, and carried off many. Often have I seen these poor victims, when fallen down to rise no more, and even when unable to lift their heads from the ground, holding up the leg to invite the starving lamb to the miserable pittance that the udder could still supply." 


\section{THE ASS.}

THe wild ass, which was formerly well known in the East, and which is frequently mentioned in Scripture, is a much finer animal than the one with which we are familiar. Roaming at liberty, in the desert or on the mountains, and so swift as to weary every pursuer, it appears as guided only by its own will. Hence "vain man " is said to "be born like a wild ass's colt ;" and it is by Divine power alone that the corruptions of his fallen nature can be checked, and that he can be brought into the path of God's commandments.

The domestic ass is so well known, as to require no particular description. In the East it is, like the wild ass, superior in all respects to our own ; and so highly is it valued, as to be preferred to the horse for many purposes. In the days of the Judges, to ride on an ass seems to have been no common distinction. One of them, Jair, the Gileadite, had thirty sons, who rode on thirty asses' colts; and they had thirty cities which are 
called Havoth-jair. Judges x. 3, 4. A similar instance is also recorded, ch. xii. 13,14. In several passages a particular kind of the domestic ass is spoken of, whose value appears greatly to have exceeded that of others.

The eastern husbandman was greatly indebted to this animal. The ox and the ass laboured together in the cultivation of the same field. Such is the reference of Isaiah, when he says, "The oxen likewise and the young asses that ear" (or till) "the ground shall eat clean provender, which hath been winnowed with the shovel and with the fan." Isa. xxx. 24. He thus foretells a season of great plenty, when the cattle shall be fed with corn better in quality, and separated from the chaff, so that it might be rendered more grateful to their taste.

These animals have been, and are still, used in many other services. From their being more hardy than horses, they are preferred for journeys across the deserts of Asia. Asses are used by most of the Mussulman pilgrims in their long and laborious journeys to Mecca. They stand in the principal streets of Cairo ready saddled for hire, and answer the same purposes as hackney coaches or cabriolets in London. The owner accompanies the ass, and running behind, goads it on.

The ass has shown itself, in some instances, capable 
of a greater amount of labour than is generally expected from that animal. One person worked a team of four asses at plough, yoked two abreast, driven in hand with reins by the ploughman, and proved that their work was equal to that of two common farmers' horses of a slight kind. The late Earl of Egremont also formed a team, consisting of six asses, and for nine months he found them of great service. They took a chaldron and a quarter of coals twice a day, in a wagon, from the canal to his lordship's house at Petworth, which showed an unlooked-for degree of strength; and at the same time they were gentle and docile.

The following journey of one of these animals is not a little remarkable. In March, 1816, an ass, the property of Captain Dundas, R.N., then at Malta, was shipped on board the Ister frigate, Captain Forest, bound from Gibraltar for that island. The ressel having struck in some sands off the Point de Gat, at some distance from the shore, the ass was thrown overboard, to give it a chance of swimming to land - a poor one, indeed, for the sea was running so high, that a boat which left the ship was lost.

A few days afterwards, however, when the gates of Gibraltar were opened in the morning, the ass presented himself for admission, and proceeded to the stable of 
Mr. Weeks, a merchant, which he had formerly occupied, to the no small surprise of that gentleman, who imagined that from some accident the animal had never been shipped on board the Ister. On the return of this vessel for repair, however, the mystery was explained; and it turned out that Valiante (so the ass was called) had not only swam safely to shore, but, without guide, compass, or travelling map, had found his way from Point de Gat to Gibraltar, a distance of more than two hundred miles, which he had never traversed before, through a mountainous and intricate country, intersected by streams, and in so short a period that he could not have made one false turn. His not having been stopped on the road was attributed to the circumstance of his having been formerly used to whip criminals upon, which was indicated to the peasants, who have a superstitious horror of such asses, by the holes in his ears, to which the persons flogged were tied; they would, therefore, as it were instinctively, shrink from taking hold of the animal.

The dulness and stubbornness of the ass, in Europe, and in England, is the consequence of ill-treatment. "We all talk of it," says a modern writer, "as the stupidest of the browsers of the field; yet if any one shuts up a donkey in the same enclosure with half a 
dozen horses of the finest blood, and the party escape, it is infallibly the poor donkey that has led the way. It is he alone that penetrates the secret of the bolt and latch. Often have we stood at the other side of a hedge, contemplating a whole troop of blood mares and their offspring patiently waiting, while the donkey was snuffing over a piece of work, to which all but he felt themselves incompetent."

A friend of the writer's was well acquainted with the habits of one of these sagacious animals. Robin was a fine creature, and he discovered more than ordinary intelligence. He carefully examined the water that was offered him, and would not touch it, unless the element, and even the vessel that contained it, were quite agreeable. Like his race, he loved too to be dry-footed, and would walk far round water sooner than pass through it. If he found those who were with him regaling themselves by his side, he sagaciously turned round his head to ask for a share; and though he did not disdain an inferior gift, he was more than commonly pleased with a piece of bun ; in the hope of which, or of something equally acceptable, he regularly went down some steps, to visit a neighbouring bakehouse.

Robin knew well how to open gates with his teeth, and raise latches with his nose; and there was more 


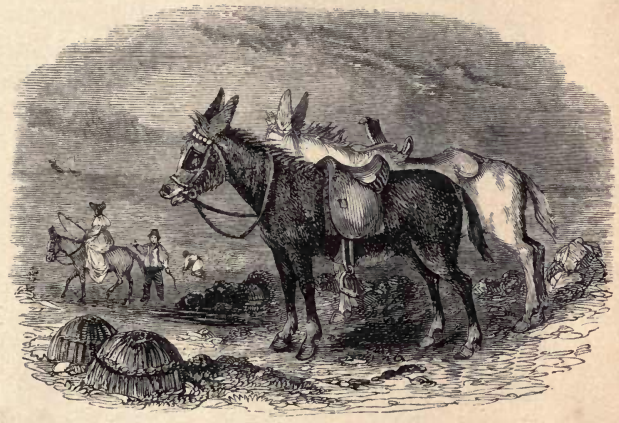

THE ASS. 

than usual difficulty in the task if he left it undone. He was accustomed to go through several of the villages of Northamptonshire two or three times a week, at the rate of from fifteen to twenty miles a day; and singularly enough, he never offered to turn into any other path than the right, not even into any one leading directly to his home, but always entered a village by the proper route, and stopped in regular succession at all the houses, often more than a hundred, at which he was accustomed to call. At one of these, those who were with him regularly partook of some refreshment; and Robin as regularly went to a shed in the yard, where he always found some provender.

This sagacious animal seemed to adapt himself fully to any change of circumstances. When he had to carry an invalid, which often happened, he passed steadily onwards, without making any calls at the places he commonly visited; and on every sabbath day, when bearing his mistress to her place of worship, he went thither without stopping. Robin was about four years old when he came to the parties now referred to ; and he became so fond of his master, that he followed him in the yard, the field, and the stable, like a dog. After fourteen years' faithful service, he ran a thorn into one of his feet, and died in consequence. 
Let none, then, think hardly of the ass, a much abused, yet valuable animal. If one should be possessed or occasionally used by a reader of this volume, the writer would ask that these facts may obtain for it kind treatment. The following should also lead to the same result. An old man, who some years ago sold vegetables in London, employed an ass to convey his baskets from door to door. Frequently did he give the industrious animal a handful of hay, or some pieces of bread, or greens, by way of refreshment and reward. He had no need of any goad, and seldom indeed was the hand lifted to urge the ass onwards. One day the kind treatment of the aged man was remarked, and he was asked if his beast were apt to be stubborn? "Ah, master," he replied, "it is of no use to be cruel; and as for stubbornness I cannot complain, for he is ready to do anything, or to go anywhere. I bred him myself. $\mathrm{He}$ is sometimes skittish and playful, and once ran away from me. You will hardly believe it, but there were more than fifty people after him, attempting in vain to stop him; yet he turned back of himself, and never stopped till he ran his head kindly into my bosom." 


\section{THE FOX.}

The Fox is an inhabitant of almost every temperate country on the face of the earth. His eye is remarkable for its brilliancy and expression; his colour is more or less red, and the end of his tail is white. He is not a little particular in the choice of his quarters, though his race is spread from Sweden to Egypt. When he purposes to settle in any spot, he narrowly examines the neighbourhood, fathoms the depth of every hole, and looks out for a convenient refuge in the hour of danger. Naturally timid, and always guided by great caution, he only lays himself down tranquilly to enjoy repose after every provision has been made for his safety.

The fox passes the day at the bottom of his hidingplace, and sallies forth in search of prey generally during the obscurity of twilight, and the darkness of night. Guided as certainly by smell as by sight, he glides along the trenches of the field to surprise the partridge on her nest, or the hare in her form. Sometimes he will lie 
in ambush near the burrows of rabbits; and at others, he chases them with the cry of a dog in the open plains. When these animals fail, he will subsist on field-mice, frogs, snails, and grasshoppers. In cultivated and wellinhabited countries, he has new resources in the refuse of kitchens, and in devastating poultry-yards. $\mathrm{He}$ is also very fond of grapes, and is often exceedingly destructive to the vineyards of France. In all cases he conceals what he obtains and cannot devour.

The sagacity of this animal is often apparent. It appears, for instance, in the choice and structure of his abode, which is not unfrequently provided with more than one outlet, by which he may escape. A fox has been known to let himself drop from the edge of a precipice, on a projecting piece of rock just below it, and thus to enter his hole or den. He is also very sagacious in digging young rabbits out of their burrows. He does not try to enter the hole, for in this case he would not only have to enlarge it, but to dig several feet along the ground, under the surface of the earth : he therefore follows the scent above, till he comes to the spot over the place where they lie; and then scratching up the earth, descends immediately, and devours them.

His stratagems in the chase have often been noticed. A fox frequently hunted in Leicestershire, was always 


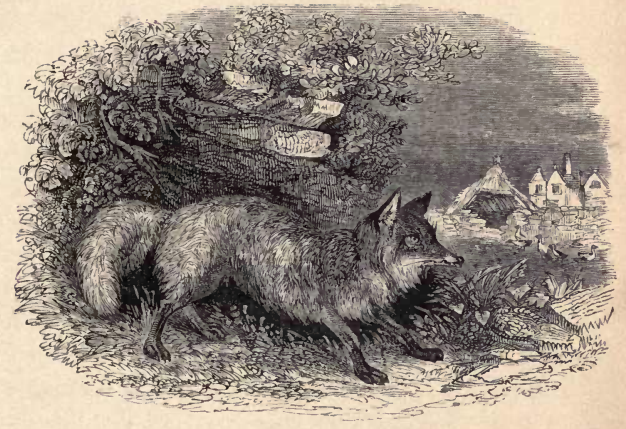

THE FOX. 

lost at a particular place, where the hounds could never recover the scent. Curiosity being excited by this circumstance, it was at last discovered that he jumped upon and ran along a clipped hedge, at the end of which was an old pollard oak tree, hollow in the middle. Into this he crept, and there he lay concealed till the alarm was over.

Another stratagem may be mentioned. Mr. Hawkins, of Pittsfield, in America, was accompanied by two bloodhounds, in pursuit of foxes. The dogs found one, which they pursued for nearly two hours, when suddenly they appeared at fault. Mr. Hawkins came up with them near a large log of wood lying on the ground, and felt much surprise at their making a circuit of a few roods without an object in view, every trace of reynard seeming lost, while the dogs continued yelping. On looking about, he discovered the fox stretched on the $\log$, apparently lifeless, and made several unsuccessful efforts to direct the dogs towards the place. At length he approached so near to the animal as distinctly to observe him breathe. But even then he exhibited no alarm; and Mr. Hawkins seizing the branch of a tree that lay close by, aimed a blow at him, which the fox evaded by a leap from his singular lurking-place, having for a time effectually eluded his enemies. 
The cunning of this animal, however, cannot always avail him. A farmer in Essex having suffered much from the depredations of a fox, determined to lay wait for the plunderer. Accordingly, on a fine moonlight night, and well knowing the track of the thief, he took his stand, and soon espied the fox padding along a clover field, with a young goose which he had just stolen slung across his neck. Just as the gun was levelled, the fox observed a hare feeding a little on one side, and nearer to the farmer. The goose was now dropped, and the fox began playing many curious antics; rolling over and over on the ground, and jumping up in the air, but still getting nearer to the hare, who was quite unconscious of a foe. At length, at one enormous spring, he made the hare his prisoner, but almost at the same moment the farmer shot the fox, and then carried home his double prize and the recaptured goose.

Cunning, it has been said, is not only met with in brutes, but in persons who are but a few removes from them. It is assuredly one mark of a degraded mind. Its aims are always selfish, and it will employ any means to accomplish its purposes. Against every approach to it, therefore, it becomes us to guard, while it is our duty and privilege constantly to seek the guidance of true wisdom. 


\section{THE HORSE.}

TuIs most interesting and valuable animal has been found varying greatly in form, size, and utility, in various regions of the Old World. So early as 1650 years before Christ, it had been domesticated by the Egyptians. On the remains of Jacob being borne from Egypt to Canaan, there went up with Joseph both chariots and horsemen; and when Pharaoh pursued the children of Israel, he did so with "six hundred chosen chariots, and all the chariots of Egypt." About two centuries later, the Olympic games were instituted in Greece ; these included horse and chariot races : and thus it appears that at a remote period, these noble animals were employed for the pleasure of man, and for securing the objects of his ambition.

The horses of Arabia are the most celebrated. There is scarcely a native of that country, however poor, who does not possess one, which he treats with the greatest kindness. Having a tent as his only habitation, himself, his wife, and his children, with the mare and her foal, rest peacefully together. His little ones are often 
seen to climb fearlessly on the inoffensive creatures, which permit them to play and caress them without injury. An Arab never beats his horse; he speaks to him in the language of friendship. The faithful servant evinces equal attachment to his master, and is so tractable, as readily to stop at his bidding, even in the midst of his most rapid course.

One instance of the attachment of an Arab to his mare has often been given, but it is worthy repetition. This valuable animal was his whole stock; and the French consul offered to purchase her for his sovereign, Louis xIv. The Arab would have rejected the proposal at once, but he had no means of supplying his most urgent wants; he had scarcely a rag to cover him, his wife and children were starving; while the sum offered was great, and would provide him and his family with food for life. At length, with great reluctance, he consented to the purchase. He brought the mare to the dwelling of the consul,- -he dismounted, -he stood leaning upon her,-he looked first at the gold, and then at his favourite,- - he sighed,- - he wept. "To whom is it," said he, "that I am going to yield thee up? To Europeans, who will tie thee close, who will beat thee,-who will render thee miserable. Return with me, my beauty, my jewel, and rejoice the 
hearts of my children." As he pronounced the last words, he sprang upon her back, his sense of poverty was gone, and he was out of sight in an instant.

The following is another instance of attachment, but of a different character. When an envoy was encamped near Bagdad, an Arab rode a mare of extraordinary shape and beauty before his tent, until he attracted his attention. On being asked if he would sell her, the reply was, "What will you give me?" "That depends upon her age; I suppose she is past five?" "Guess again," said he. "Is she four?" "Look at her mouth," said the Arab, with a smile. On examination, she was found to be rising three; and this, from her size and symmetry, greatly enhanced her value. The envoy said, "I will give you fifty tomans," - a coin nearly of the value of a pound sterling. "A little more," said the Arab, apparently amused. "Eighty." "A hundred." He shook his head, and smiled. At last the offer came to two hundred tomans. "Well," said the Arab, "you need not tempt me further; it is of no use; you are a rich elchee," (meaning a nobleman,) "you have fine horses, camels, and mules, and I am told you have loads of silver and gold. Now," added he, "you want my mare, but you shall not have her for all you have got." 
Nor is strong attachment to this faithful animal confined to the Arab. Our own countryman, the enterprising traveller, Major Denham, thus refers to the death of his favourite horse, in one of the most desert spots of Central Africa. "There are a few situations in a man's life, in which losses of this nature are felt most keenly, and this was one of them. It was not grief, but it was something nearly approaching to it; and though I felt ashamed of the degree of derangement I suffered from it, yet it was several days before I could get over the loss. Let it, however, be remembered, that the poor animal had been my support and my comfort ; nay, I may say, companion, through many a dreary day and night; had endured both hunger and thirst in my service ; and was so docile, that he would stand still for hours in the desert, while I slept between his legs, his body affording me the only shelter that could be obtained from the powerful influence of a noon-day sun : he was the fleetest of the fleet, and ever foremost in the chase."

Julius Cæsar mentions these animals, in his account of the invasion of our native isle. Many war-chariots, drawn by horses, were used in the army of the ancient Britons. Scythes fastened to the end of the axle-trees, swept down every thing before them, and spread 
devastation and terror around; while the horses appear to have been managed with great dexterity. For a long time oxen alone were used for the plough, but towards the end of the tenth century, horses were sometimes employed. The earliest notice of their use in field labour, is said to be on one of the pieces of tapestry worked at Bayeux, in the year 1066 ; it has the figure of a man driving a horse, to which a harrow is attached. From that period to the present, this animal has been treated with various degrees of attention, until it has become fully and eminently adapted to various and important purposes. Some interesting particulars will now be given of different species.

\section{THE CAVALRY HORSE.}

In adverting to the employment of the horse in war, the mind at once recurs to the sublime passage in the book of Job :

\section{" Hast thou given the horse strength?}

Hast thou clothed his neck with thunder?

Canst thou make him afraid as a grasshopper?

The glory of his nostrils is terrible. 
He paweth in the valley, and rejoiceth in his strength:

He goeth on to meet the armed men.

He mocketh at fear, and is not affrighted;

Neither turneth he back from the sword.

The quiver rattleth against him,

The glittering spear and the shield.

He swalloweth the ground with fierceness and rage;

Neither believeth he that it is the sound of the trumpet.

He saith among the trumpets, $\mathrm{Ha} ! \mathrm{ha}$ !

And he smelleth the battle afar off,

The thunder of the captains, and the shouting." -Јов xxxix. 19-25.

It was said in reference to the time when Israel should have a king; "He shall not multiply horses to himself, nor cause the people to return to Egypt, to the end that he should multiply horses," Deut. xvii. 16 . The reason of this prohibition was, that multiplying horses for chariots of war or state, would increase the splendour of the monarch, and form a ground of confidence distinct from, and inconsistent with, confidence in God. Egypt abounded in horses; and the desire of their increase would induce the prince to encourage trade with that kingdom; and this might lead to the corruption or subjugation of the Israelites by the Egyptians. Still further, they might be tempted to extend their dominions by means of cavalry, and so be scattered among the surrounding idolatrous nations ; thus they would cease to be that distinct and separate people which Jehovah intended they should be. 
The military history of this and other lands is distressing to every benevolent mind, yet interesting facts may be gleaned from it in reference to the horses employed. The effect of discipline, for instance, is not a little striking. Thus, in one of the insurrections of the Tyrolese, about thirty years ago, they took fifteen Bavarian horses, and mounted them with their own men; but in a skirmish with a squadron of the same regiment, the horses no sooner heard the sound of the trumpet, and recognised the uniform of their old masters, than they set off at full gallop, and carried their riders, notwithstanding all their efforts, into the Bavarian ranks, where they were made prisoners.

Some time ago there was a horse in the artillery stud at Woolwich, which, while in the riding-school, appeared a most docile and finely-trained animal. At the word of command, he would lie down, and not rise till he was ordered; he would bow in the most dignified manner to visitors ; and performed feats with unvarying obedience. But the instant he was taken out of doors, and found himself in the open air, or on the roads, he became altogether unmanageable; and when he could not throw his rider, which he tried to do again and again, he lay down and rolled about. It appears that when first purchased, he proved extremely vicious, but 
being a fine horse, pains were taken to break him in, and as it seems successfully within the walls of the riding-school, but out of doors discipline did not operate; here he was unruly as before. How often is it the case even with mankind, that circumstances of time and place alone restrain an individual from showing the natural inclinations of the heart! These may be partially subdued, but evil dispositions will continually appear when opportunities occur, until there is "a new heart and a right spirit."

The horses of the British army often arrest the attention of visitors to London, and others by whom they are occasionally seen; they are indeed a noble race. Soon may the need for employing them for war be unknown, and the world be as familiar with the "peaceable fruits of righteousness," as it has been for ages with deeds of blood. To such a state some advance is made, whenever corrupt feeling is subdued in the human heart by the Almighty operation of the Holy Spirit. May this take place in the bosom of every reader! Peace around must arise from peace with God and peace within. "He that hateth his brother is a murderer ;" but "love is the fulfilling of the law," and the preparative for the blessed society of "the allreconciling world." 
THE HORSE.

\section{THE ROAD HORSE.}

This animal was for a long period used by travellers. Our ancestors did not travel in carriages, or carry their goods in carts; their horses conveyed themselves and their merchandize. In the reign of Queen Elizabeth, some persons were robbed in open day, within the hundred of Beyntesh, in Berkshire ; and it is said, "they were clothiers, and yet travailed not withe the great trope of clothiers; they also carried their money openlye in wallets upon their saddles." Here we see the common mode of conveyance at that time, and the necessity for travelling in company.

On two persons making the journey from Glasgow to London, on horseback, in 1739, they found no turnpikeroad till they came to Grantham, within one hundred and ten miles of the metropolis. From time to time, they met with strings of packhorses, from thirty to forty in a gang ; still the common mode of transporting goods from one part of the country to another. The leading horse of the troop carried a bell, to give warning to passengers coming in an opposite direction; and when these trains of horses came up with their packs, the travellers were compelled, from the narrowness of 
the causeway, to make way for them, and pass to the road-side. For many years after this, the letter-bags from the Post Office were intrusted to boys, who conveyed them on horseback.

The qualities of the horses now in use, are often very pleasing. To mention one instance of sagacity; the writer was a short time ago visiting a gentleman who had a horse, which had long been in his service. Whenever his master's foot was heard approaching the yard of his stable, he promptly advanced to put his head over the gate, and by sounds of pleasure hailed his coming. Hero had been a creature of no common spirit and strength ; and in his early days, would allow nothing to pass him on the road. Indeed the neighbours of his owner foretold serious accidents, and even death, as the result of his unusual speed and power. But happily they were false prophets; his master's voice was a law which Hero did not break. The lady of his owner, at the time referred to, was a great invalid, and had to be lifted into, and out of the chaise. But he seemed fully to understand what was doing. No one was required to stand at his head, nor even to hold the reins; he stood perfectly still; nor was he startled for a second, by the passing of any vehicle. He waited with remarkable patience till every arrangement was 
complete, and only at the word of command, did he proceed with his usual alacrity.

Another instance of sagacity is thus given by Cunningham, in his account of New South Wales. "A friend of mine, in the habit of riding a good deal, found that whenever he approached a gully, his horse invariably opposed his wishes to cross at the particular spot he had been accustomed to, always endeavouring to lead off to another part of the gully, where no passage was known to exist by his rider. Resolving to see whither the cunning rogue would go, he gave him the rein, and soon found himself carried over the gully, by a route he had never before followed. Still, however, thinking that the former way was nearest, he was curious enough to have both measured, when he found the horse's judgment correct; that way being nearest by several hundred yards."

The exercise of memory is sometimes as remarkable as this operation of judgment. "A friend of ours," says the author of a valuable volume, entitled "The Horse," " rode thirty miles from home on a young horse which he had bred, and which had never before been in that part of the country. The road was difficult to find, but by dint of inquiry, he at length reached the place he sought. Two years passed over, and he had 
again occasion to take the same journey. No one rode this horse but himself, and he was perfectly assured that the animal had not since been in that direction. Three or four miles before he reached his journey's end, he was benighted. He had to traverse moor and common, and he could scarcely see his horse's head. The rain began to pelt. 'Well,' thought he, 'here I am, far from any house, and know not, nor can I see an inch of my road. I have heard much of the memory of the horse,-it is my only hope now, - so there,' throwing the reins on his horse's neck, 'go on.' In half an hour, he was safe at his friend's gate."

A statement not less singular will be found in another interesting work, entitled "The Menageries." "We knew a horse (and have witnessed the circumstance), which, being accustomed to be employed once a week on a journey with the newsman of a provincial paper, always stopped at the houses of the several customers, although they were sixty or seventy in number. But, further, there were two persons on the route who took one paper between them, and each claimed the privilege of having it first on the alternate week. The horse soon became accustomed to this regulation; and although the parties lived two miles distant, he stopped once a fortnight at the door of the half-customer at Thorpe, 
and once a fortnight at that of the other half-customer at Chertsey; and never did he forget this arrangement, which lasted several years, or stop unnecessarily, when he once thoroughly understood the rule."

\section{THE COACH HORSE.}

Familiar as this phrase is now, it is one of modern date. It was not until the reign of Elizabeth, that coaches were used; but the fashion which then came in, soon spread. These vehicles were, however, heavy and unwieldy, and the rate of travelling was as slow as might be supposed from their clumsiness and that of the horses which drew them. When King George Ir. died, in 1760 , the Duke of Devonshire reached home from Chatsworth in Derbyshire, in three days; but a fourth, and even a fifth day passing, without the arrival of the Duke of Rutland, who had not to travel so far by thirty miles, the Speaker of the House of Commons apologized for him by stating, that the former came at a prodigious rate, - not less, he said, than fifty miles a day! 
At that time it was common to dine on the road to Epsom, a distance of sixteen miles from London, the journey taking nearly the whole day; and it is stated, that when the poet Cowley lived at Chertsey, which is about two and twenty miles from town, he told a friend whom he expected on a visit, that he might make a comfortable journey by passing the night at Brentford, which may now be reached in about an hour.

A few years ago the following statements were made in reference to coach travelling:- The Edinburgh mail runs the distance, four hundred miles, in forty hours; and watches are often set by its arrival, in many places. Stoppages included, this approaches eleven miles in the hour; and much the greater part is done by lamp-light. An Exeter day-coach passes over its ground, one hundred and seventy three miles, in twenty hours; the mail, before it was placed on the railroad, went the distance in little more than seventeen hours. Both are instances of remarkable travelling, considering the natural unevenness of the country through which the vehicles have to pass. And to mention only one more fact of this kind, a nobleman is said to have spoken in the House of Peers on one night, and to have been at his own door in Durham, two hundred and fifty miles off, the next, having travelled that dis- 
tance in a chariot and four. Attempts to secure such great speed have often been accompanied by much severity and cruelty; but the improved state of the roads, the employment of a large number of horses in short and well arranged stages, and the constant guarding against all avoidable delays, have frequently gained the desired end without these great evils. The introduction of railroads has produced other changes, the results of which cannot be calculated.

Horses require to be carefully broken, to answer the purposes for which they are used. Various and continued means are commonly necessary, but James Sullivan, an ignorant awkward rustic, of the lowest class, and a horsebreaker, obtained the name of "the whisperer," from a most extraordinary art he possessed of controlling, in a secret manner, and taming into the most submissive and tractable disposition, any horse or mare that was notoriously vicious and obstinate. He practised his skill in private, and without any apparently forcible means. In the short space of half an hour, his magical influence would bring into perfect submission and good temper even a colt that had never been handled; and the effect, though instantly produced, was generally durable. When employed to tame an outrageous animal, he directed the stable in which he 
and the object of the experiment were placed to be shut, with orders not to open the door until a signal was given. After a tête-⿳亠㐅⿵冂-tête between him and the horse for about half an hour, during which little or no bustle was heard, the signal was made, and upon opening the door, the horse was seen lying down, and the man by his side playing familiarly with him, like a child with a puppy dog. From that time he was found perfectly willing to submit to any discipline, however repugnant to his nature before.

The narrator of this account says, "I once saw his skill on a horse which could never before be brought to stand for a smith to shoe him. The day after Sullivan's half-hour lecture, I went, not without some incredulity, to the smith's shop, with many other curious spectators, where we were eye-witnesses of the complete success of his art. This, too, had been a troop-horse ; and it was supposed, not without reason, that, after regimental discipline had failed, no other would be found availing. I observed that the animal appeared afraid whenever Sullivan either spoke or looked at him. How that extraordinary ascendancy could have been obtained, it is difficult to conjecture! He seemed to possess an instinctive power of inspiring awe, the result perhaps of a natural intrepidity, in which I believe a great part of 
his art consisted, though the circumstance of the têtea-tête shows that upon particular occasions something more must have been added to it."

It is stated that breathing in to the nostrils of a horse will be followed by a similar result. A mule, that would suffer no person to handle it, was by this means rendered so quiet before the operator left the stable, that it would stand still and suffer itself to be rubbed.

Horses like to be together. Many which are perfectly quiet with company, will not remain by themselves a minute in a field. "My neighbour's horse," says Mr. White, of Selborne, "will not only not stay by himself abroad, but he will not bear to be left alone in a strange stable, without discovering the utmost impatience, and endeavouring to break the rack and manger with his fore-feet. He has been known to leap out of a stable window after company; and yet, in other respects, he is remarkably quiet."

One of the advantages of such society may often be observed. There are parts of the body of a horse which the animal cannot reach to rub when they itch; thus he can neither bite with his teeth, nor scratch with his hindfoot, those which are about the shoulder. What then is he to do? He goes to another horse, and gently bites the place on which he wants to be bitten, and 
the kind office which is required is promptly performed by his equally sagacious companion.

Sometimes the attachment frequently discovered to subsist between animals of the same species, becomes unusually strong. So it was with two Hanoverian horses, which had long served together in the German brigade of artillery, during the Peninsular war, drawing the same gun, and being inseparable companions in many battles. At last one of them was killed, and after the engagement, the survivor was picqueted as usual, and his food was brought to him; but he refused to eat, constantly turning round his head in pursuit of his friend, and sometimes neighing as if to call him. All the care that could be bestowed on him was of no avail ; he was surrounded by other horses, but he did not notice them; and he died shortly afterwards without once tasting food. "A gentleman who witnessed this circumstance assured me," says Mr. Jesse, "that nothing could be more affecting than the whole demeanour of this poor horse." 


\section{THE SUFFOLK PUNCH.}

A sandy tract of land in the neighbourhood of Woodbridge, has long been celebrated for producing horses, which, though awkward in appearance, exceed all others in draught. The Suffolk punches, or Suffolk punch sorrels, as they are sometimes called, are of various sizes, but the smaller ones are generally the most serviceable. A single horse of this kind was known to draw in a cart, ten sacks of flour, each weighing twenty stone and a half, on a heavy road, for five or six miles.

\section{THE GALLOWAY.}

To use the words of Dr. Anderson : "There was once a breed of small elegant horses in Scotland, similar to those of Iceland and Sweden, and which were known by the name of galloways ; the best of which sometimes reached the height of fourteen hands and a half. One of this description I possessed, it having 
been bought for my use when a boy. In point of elegance and shape, it was a perfect picture; and in disposition was gentle and compliant. It moved almost with a wish, and never tired. I rode this little creature for twenty-five years ; and twice in that time, I rode a hundred and fifty miles at a stretch, without stopping, except to bait, and that for not above an hour at a time. It came in at the last stage with as much ease and alacrity as it travelled at first. I could have undertaken to have performed on this beast, when it was in its prime, sixty miles a-day for a twelvemonth, without any extraordinary exertion."

Many of the galloways now in use, are brought either from the New Forest, or Wales ; but they are diminished in number, being scarcely sufficient to supply even the neighbouring districts ; and they are far inferior in form and value. The Welsh ponies are beautiful little creatures; they can live on any fare, and it is said they cannot be tired out. On Dartmoor, there is a very hardy and sure-footed race of ponies, well fitted for the rough roads and dreary wilds of that mountainous country. One of a smaller kind, the Exmoor ponies, carried his owner, who rides fourteen stone, from Bristol to South Molton, eighty-six miles, beating the coach which goes the same road. The Shetland pony, an 
inhabitant of the extremest northern Scottish isles, is a very small, and often a beautiful animal ; it is remarkably strong for its size, and also exceedingly docile.

"A friend of ours," says a writer already quoted, "was not long ago presented with one of these elegant little animals. He was several miles from home, and puzzled how to convey his newly acquired property. The Shetlander was scarcely more than seven hands high, and as docile as he was beautiful. 'Can we not carry him in our chaise ?' said his friend. The strange experiment was tried. The Sheltie was placed in the bottom of the gig, and covered up as well as could be managed with the apron; a few bits of bread kept him quiet; and thus he was safely conveyed away, and exhibited the curious spectacle of a horse riding in a gig."

The eminent naturalist, Mr. Bell, mentions another case, which is equally amusing. Some time since he was passing, rather late in the evening, through one of the streets in the immediate neighbourhood of London, when he observed two men walking briskly along, with a beautiful little pony trotting by their side, without either bridle or halter. Presently, one of the men, who seemed on the best possible terms with his little steed, passed his arm round its body, and lifting it with ease 
from the ground, carried it for some distance; then setting it down, he threw one leg over its back, and half rode, half walked, with his feet touching the ground on either side. After a time he again carried the horse a short distance ; and, at length, he took it up the steps of a shop, and disappeared with it at the door.

It is truly lamentable that the horse, which is so valuable to man, should often be treated with great rigour and cruelty. Such objects should certainly not be seen as that on which the poet's eye was fixed, when he said :

"Will none befriend that poor dumb brute?

Will no man rescue him ?-

With weaker effort, gasping, mute,

He strains in every limb.

"Spare him, O spare :-he feels, he feels !

Big tears roll from his eyes :

Another crushing blow !-he reels,

Staggers, and falls, and dies.

"Shame that of all the living chain

That links creation's plan,

There is but one delights in pain,

The savage monarch,--man!"'

One lesson of humanity may be derived from Busbequius, who was ambassador at Constantinople in the seventeenth century. "No creature," he says, " is so gentle as a Turkish horse, nor more respectful to his 
master, or the groom that dresses him. The reason is, because they treat their horses with great lenity. I myself saw, when I was in Pontus, how indulgent the countrymen were to young colts, and how kindly they used them. They would stroke them, bring them into their houses, and almost to their tables, and use them even like children. The grooms that dress them are as indulgent as their masters; they frequently sleek them down with their hands, and never use a cudgel but in cases of necessity. This makes their horses great lovers of mankind ; and they are so far from kicking, wincing, or growing untractable by this gentle usage, that you will hardly find a masterless horse among them." The treatment of the Turkish post-horses at the present day, however, is very inhuman.

We know, too, who hath said, "A righteous man regardeth the life of his beast ;" and again, "He shall have judgment without mercy, that hath showed no mercy." Inferior creatures should therefore be constantly treated with kindness. "I would not keep a horse," said an excellent man, "that did not love me;" and well he might, for he daily cared for the inmates of his stables, in remembrance of Him to whose goodness he felt himself constantly indebted. 


\section{THE WILD CAT.}

THE common wild cat is the only animal of this family that is found in the British Islands, and there it is very seldom met with. In the south of England it was formerly much more common than at the present time; but it has been forced to yield to the dominion of man, and is now almost extinct. Though not numerous, these creatures may still be found among the woody mountainous districts of Cumberland and Westmoreland. In the wild parts of the north of Scotland, and in Ireland, they are more abundant; and in some countries of the former, there are men who obtain a livelihood by the hunting and destroying of wild cats and other animals, which make considerable inroads on both the flocks and the poultry. They are rather smaller than domestic cats.

The lodgment of these animals is in hollow trees, in the fissures of rocks, and in deep and narrow holes found on the face of fearful precipices. From thence they issue forth in pursuit of prey, but chiefly during the 
night. It consists of various kinds of birds and quadrupeds, among which are hares and rabbits. Wild cats are caught or destroyed chiefly to prevent the ravages they commit.

\section{THE DOMESTIC CAT.}

This animal is a variety of the wild species, and partakes, in some degree, of its native ferocity. In ancient Egypt, the cat was held in sacred veneration. It was considered a capital crime to kill one wilfully; and to kill one accidentally, exposed the individual to severe punishment. A similar feeling has prevailed in other countries. It is stated by Herodotus, the Greek historian, that "when a cat died, it was embalmed, and interred with honour; and that the inhabitants of the house shaved their eyebrows in token of sorrow." In Turkey, cats are treated with a like regard.

It appears from an ancient law of one of the Welsh princes, that in his time a cat was a rare and valuable animal. A penny for a kitling before it could see, which was doubled from that time till it caught a mouse, and quadrupled for a mouser, was a very high price, 
considering the relative value of money at that time. A person who had stolen the cat that guarded the prince's granary, was to forfeit a milch ewe, its fleece, and lamb; or as much wheat as, when poured on the cat while suspended by the tail, with the head touching the floor, would form a heap high enough to cover the tip of the former.

Cats, which have greatly multiplied since that time, are very cleanly. In cold weather, they show their fondness for warmth, by securing a place as near as possible to the fire of the rooms into which they are admitted. If noticed and caressed, they give many proofs of pleasure, by their singular noise called "purring," as well as by various motions. An attack produces an opposite effect, and displeasure is equally manifest. Cats sleep lightly, thus reminding us of the wild state, in which heavy slumbers would be injurious to them as creatures of prey.

The value of cats in destroying rats and mice is well known. Their patience and perseverance at such times, are not a little remarkable. Nor can the writer forget the complacency and pleasure of one of these creatures when bringing a rat or mouse to some one accustomed to caress her, as if she wished for a few pats on the side, or some gentle words, as a reward for her labour. 


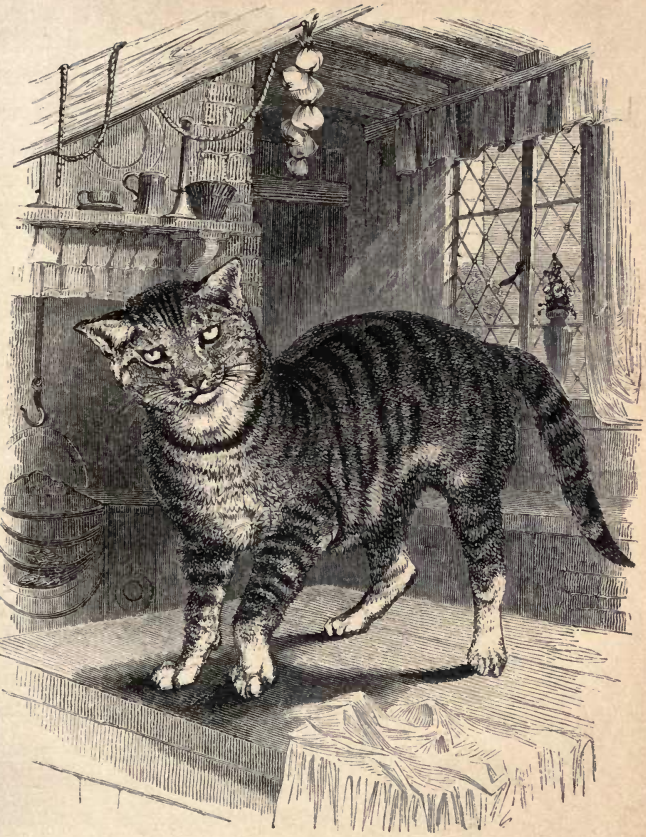

THE CAT. 
Of attachment to these animals there are many instances. An artist of Berne, named Gotfried Mind, gave his chief and zealous attention to the painting of cats and bears. The truth and excellence with which he represented them were without precedent; and his drawings of the former especially were so admirable, that he attained the honourable, though rather awkward title, of "the Raphael of cats." Minette, his favourite, was always near him when at work, and he seemed to carry on a sort of conversation with her by gestures and words. But a formidable trial came, of his cherished feeling. Symptoms of madness having appeared among the cats of Berne, in the year 1809, the magistrates gave orders for their destruction. Mind showed the greatest distress when he heard this mandate. He kept Minette in secret; but his sorrow for the death of eight hundred cats was inexpressible. To sooth his regret, he painted these animals with increased diligence; and amused himself during the long evenings of the ensuing winter in cutting chestnuts into miniature figures of bears and cats. These trifles were executed with such great skill, that he was unable to supply the demand for them. He died in 1814 .

A strong attachment to cats was cherished by Mrs. Griggs, of Southampton Row, London, whose decease 
took place in the early part of 1792 . Her executors found in her house twenty-eight dead and eighty-six living cats. She left her black servant $150 l$. per annum to maintain the survivors and himself. Such conduct is, however, very reprehensible. Inferior creatures are not intended to be pampered; and those who pay them excessive attention, diminish, instead of promoting, their enjoyment. At the same time they degrade and injure themselves, and incur fearful guilt by the neglect of duties of the most solemn obligation, for the performance of which they are accountable to God.

Of the sagacity of the cat many instances might be given. Thus, it is stated by Mr. Sharon Turner, that his cat, when she wished to be let into the room, always rose up, and shook the handle of the door outside, till she was admitted; an act which she had taught herself from seeing the family open it to let themselves out and in.

Another case is more remarkable. In the early part of May, 1832, when insects, in consequence of the cold, flew low, and of course swallows were forced to hawk for their prey by skimming the surface of the ground, a wily cat gave a singular proof of her skill. She stretched herself on the sunny grass-plot, with her legs extended as if she were dead; the flies collected 
about her, and the swallows, dreaming of no harm, pounced down on the flies; when puss, perceiving her prey within reach, made a rapid spring, and at her pleasure struck down with her paw a poor thoughtless bird. The best marksman knows how difficult it is to shoot a swallow on the wing; yet the cat found her patience, cunning, and activity rewarded by unfailing success, whenever a swallow ventured within her reach.

The following almost incredible instance of sagacity is related by De la Croix. "I once saw," he says, " a lecturer upon experimental philosophy place a cat under the receiver of an air-pump, for the purpose of demonstrating the very certain fact, that life cannot be supported without air and respiration. The lecturer had already made several strokes with the piston, in order to exhaust the receiver of its air, when the animal, who began to feel herself very uncomfortable in the rarified atmosphere, was fortunate enough to discover the source from whence her uneasiness proceeded. She placed her paw upon the hole through which the air escaped, and thus prevented any more from passing out of the receiver. All the exertions of the philosopher were now unavailing: in vain he drew the piston, the cat's paw effectually prevented its operation. Hoping to effect his purpose, he let air again into the 
receiver, which as soon as the cat perceived, she withdrew her paw from the aperture; but whenever he attempted to exhaust the receiver, she applied her paw as before. All the spectators clapped their hands in admiration of the wonderful sagacity of the animal, and the lecturer found himself under the necessity of liberating her, and substituting in her place another." But surely there could be no necessity for so cruel an experiment, while the sagacity of the cat might have pleaded for humanity to her race.

To the instances of sagacity now given, may be added a few others. A gentleman was recently visiting a friend, in whose house were a favourite cat and dog, when one morning there was a tremendous storm of thunder and lightning. Pincher was in the drawingroom, not a little disturbed, when the cat, who lived most amicably with him, walked in, mewing with all her might. She invited him in the most expressive way possible, and one which it was evident he understood, to accompany her; but as he continued to refuse, she left the room. Soon afterwards she mewed so piteously, that the observer could not resist the appeal, and found her close to the open door of his sleeping apartment. She ran to him, rubbed herself against him, and then crept under the wardrobe which was in the 
room. Hearing two voices, he discovered that she had brought down one of her kittens from the garret, and lodged it there for safety, of which she had evidently wished Pincher to take charge. Having, however, confided this little one to her new friend, she hastened up stairs. He then followed her with the kitten, placed it beside her, moved their little bed further from the windows through which the lightning had flashed so vividly as to occasion her alarm, and remained there till the storm subsided, and all was calm.

On the following morning, much to his surprise, this gentleman, who knew the cat was always in the habit of going down to breakfast with the lady of the house, found her waiting for him at the door of his apartment. She had resisted all the caresses of her mistress to induce her to leave it, accompanied him down stairs, sat by him during breakfast with all the attention she could display, and then returned to her family. What could she have done more to express her feeling,-one unhappily so rare among human kind-gratitude?

Of the care of this animal for her young, the following is another singular instance. A lady residing in Glasgow, had a handsome cat sent to her from Edinburgh, conveyed in a close basket, placed in a carriage. She was carefully watched for two months, but having 
produced a pair of young ones at the end of that time, she was left to herself, and soon disappeared with both her kittens. The lady in Glasgow wrote to her friend in Edinburgh deploring her loss ; but about a fortnight after her disappearance, her well-known mew was heard at the street door of her old mistress, for she was there with both her kittens; they in their best state, but she was very thin. How much must she have done and suffered to accomplish her object! It is obvious she could carry only one kitten at a time, and the distance from Glasgow to Edinburgh is forty miles; so that, if she brought one kitten part of the way, and then went back for the other, and thus conveyed them by turns, she must have travelled at least one hundred and twenty miles. Her sagacity must have also suggested, with many other precautions, the necessity of journeying in the night, for the safety of her young.

Cats have become the defenders of their master's property. A man who was sentenced to be transported for robbery, stated to a gentleman, that he and two others broke into a house near Hampton Court; in the act of plundering it, a large black cat flew at one of the robbers, and fixed her claws on each side of his face; he added, that he never saw any man so much frightened.

Another of these creatures is said to have watched by 
the couch of her dying master. When life was extinct, she could scarcely be removed from the room where the corpse remained; and after the funeral, though often driven and carried from the church-yard, she was sure to return to the grave, on which, regardless of cold and hunger, she would lie for hours. Such instances are doubtless rare, but when a cat is treated kindly and gently, she will commonly find many ways of expressing her gratitude.

A remarkable circumstance may here be stated, which the writer received on authority above all suspicion. In a retired village in Devonshire, there was living very lately a family in humble circumstances, the heads of which were numbered among the pious poor. The eldest daughter was taken ill, and long continued a sufferer from disease. Her appetite was, in consequence, very delicate, and at this her parents were much concerned, as they had no means of ministering to her wants. Living at the distance of seven or eight miles from any town, they were beyond the range of the benevolent visits often made in such neighbourhoods, nor were there at hand any persons to whom in their extremity they could apply for relief.

At this crisis, however, the gracious providence of God provided for them by very singular means. A 
favourite cat brought one day into the room of the invalid, a rabbit she had caught and killed, without at all injuring it for food, and thus a grateful meal was provided. Never was she known to do so before, but now she did so without variation from day to day, until the sufferer was removed from the present world, and such aid was no longer needed. The narrator of the fact received it from the mother of the invalid, who told it with many tears when he visited her cottage; she thought of one whom she tenderly loved, and for whom relief was so singularly found.

To live like cat and dog, is a proverb for a life of ceaseless conflict; but one case at least may be mentioned of a very different state. "I had," says $M$. Wenzel, "a cat and dog, which became so attached to each other, that they would never willingly be asunder. Whenever the dog got any choice morsel of food, he was sure to divide it with his whiskered friend: They always ate socially out of one plate, slept in the same bed, and daily walked out together. Wishing to put this apparently sincere friendship to the proof, I one day took the cat by herself into my room, while I had the dog guarded in another apartment.

"I entertained the cat in a most sumptuous manner, being desirous to see what sort of a meal she would 
make without her friend, who had hitherto been her constant table companion. The cat enjoyed the treat with great glee, and seemed to have entirely forgotten the dog. I had had a partridge for dinner, half of which I intended to keep for supper. My wife covered it with a plate, and put it into a cupboard, the door of which she did not lock. The cat left the room, and I walked out upon business. My wife, meanwhile, sat at work in an adjoining apartment. When I returned home she related to me the following circumstances :The cat, having hastily left the dining-room, went to the dog, and mewed uncommonly loud, and in different tones of voice; which he from time to time answered with a short bark. They then went both to the door of the room where the cat had dined, and waited till it was opened. One of my children opened the door, and the two friends entered the apartment. The mewing of the cat 'excited my wife's attention. She rose from her seat, and stepped softly up to the door which stood ajar, to observe what was going on. The cat led the dog to the cupboard which contained the partridge, pushed off the plate which covered it, and taking out my intended supper, laid it before her canine friend, who devoured it greedily.

"Probably, the cat by her mewing had given the dog 
to understand what an excellent meal she had made, and how sorry she was that he had not participated in it; but, at the same time, had given him to understand that something was left for him in the cupboard, and persuaded him to follow her thither. Since that time, I have paid particular attention to these animals, and am perfectly convinced that they communicate to each other whatever seems interesting to either. 


\section{THE SQUIRREL.}

This light and lively little creature has often gratified the sight of the visitor of the country, in his woodland rambles. Its activity and agility, when favourably situated, are truly surprising; and its sudden turns, when moving with the greatest rapidity, are almost too quick for the sight to follow. On the ground, the squirrel has less opportunity of displaying its powers, and though it advances rapidly, it is by means of jumps or gallops.

If after admiring this lively little creature carrying its tail on its back, shelling its nuts, sitting upright and using its fore feet like hands, or leaping from branch to branch with amazing agility, we wish to know something of its habits, these may be easily ascertained. It chooses a tall tree for its abode, and prefers a natural hollow, where the branches begin to fork into smaller ones. Here, first making a level, it builds its nest, lines it with wool or any other soft substance, leaves only one opening just large enough for itself, defends this by a cone which throws off the rain, and so protects the whole, 
that the little dwelling is secure even amidst a storm. So far its ingenuity is obrious. It is also vigilant; at the slightest appearance of danger bounding even from tree to tree, and rarely venturing to stop until far distant from the cause of its alarm. Nor should its frugality be forgotten. Its food consists chiefly of nuts and acorns; these are, however, seldom found in the nest, but carefully laid up in the hollows of the tree, where the store is only touched in cases of necessity. Thus it provides for a time of want: this is one of the many lessons which may be learned from going to animals, and "considering their ways."

The blindness of instinct, however, is often displayed by a tame squirrel, for after having been captured in the nest, and removed from the influence of instruction and example, it is impelled to hoard, though to do so is no longer necessary. If an inferior food be given it, and another more agreeable to its palate be offered shortly after, it will not carelessly drop the former, or throw it hastily away, but will endeavour to conceal the one before it receives the other. The regularity of its action is remarkable in a state of captivity; for if kept in a circular moving cage, and allowed occasionally to go out, it will frequently return of its own accord to run round its wiry tread-mill. 


\section{$12+3$}

hach

Fifl

$12(2 x)=-130)^{3}$

MLe

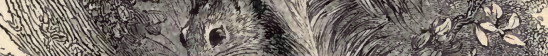

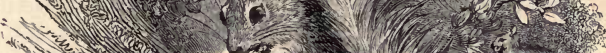

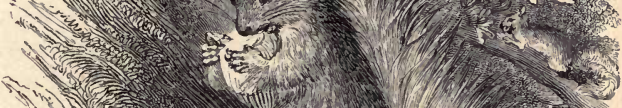

crances

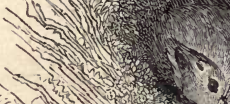

$x^{2}(2)$

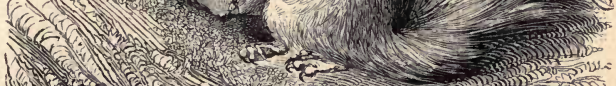

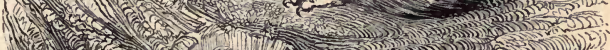

(1) (1) Min $x$ situ MP -3 s.

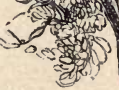

t.

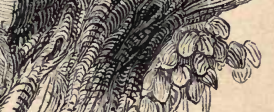

THE SQUIRREL. 
The squirrel, it appears, may be rendered very familiar. A gentleman procured a common squirrel from a nest, reared it, and rendered it very tame. It was kept in a box nailed against the wall, about six feet from the floor, wired in front, and having a small round aperture at one end, to allow the animal to enter. Below this, a rope was suspended to the end of the box, which touched the ground, and by it the squirrel ascended and descended to its abode.

It became extremely playful, familiar with every one of the family, but especially attached to its master, who generally carried it about with him in his coat pocket, that on the right being made purposely on the outside. It used to watch very narrowly all its master's movements; and whenever he was preparing to leave home, it ran up his legs, and entered his pocket, from whence it would peep at passengers as he walked along the streets; but it did not venture to get out. Yet no sooner did he reach the outskirts of the city, than the squirrel leaped on the ground, ran along the road, climbed to the tops of trees with great rapidity, and nibbled at the leaves and bark; and if he walked on, it would descend, scamper after him, and again enter his pocket. In this manner, it would amuse itself during walks of miles, which its master frequently took. 
80

BRITISH QUADREPEDS.

Whenever it heard a carriage or a cart, it became much alarmed, and always hid itself till the object of its fears had passed by. So familiar was it, that when its master was in company with strangers, it would leave his pocket, and run all over him.

This gentleman had a dog which was trained not to touch the squirrel, but would never be quite friendly with it, though the little creature made many efforts to secure friendship. Whenever Filbert attempted to pass over the body of Ponto, he always showed his displeasure by a growl. When the latter was asleep, the former used to take great delight in teasing him, by making a rapid descent from his box, scampering over the dog's body, and then quickly ascending the rope. Again and again would it repeat this sport to the great annoyance of Ponto, who sometimes at last became very angry, when Filbert would end his gambols, and sit peeping through the grating of his box.

This interesting little creature met with its death by its master inadvertently leaning back in a chair while it was in his pocket. On being squeezed, poor Filbert gave a slight scream, and when taken out was found lifeless.

The squirrel is exposed to a considerable change of colour, and becomes grey in the northern regions. The 
inhabitants of the Lapland Alps, it is said, contrive, by means of their wooden bows, to procure, in the course of a winter, a considerable number of squirrels for the sake of their skins. In spring and autumn some change appears to take place in the colour of the fur in this country. In the summer the fur is uniformly red, and much coarser, and the pencils of the ears also are lost; in the winter the sides of the body assume a greyish tint, the pencils of the ears are long and full, and the fur softer and thicker. 


\section{THE MOLE.}

THIs animal is common in every part of Europe, except Ireland and Greece, Orkney, and Shetland. It is not met with in any of the Hebrides, excepting Bute ; and is unknown, in some of the northern and western districts of the Highlands of Scotland, but is distributed over all the other parts of Britain, from the level of the sea to the height, in some places, of a thousand feet or more, although it is more abundant in the lower and richer grounds.

It exhibits several varieties as to colour. In the loamy parts of Richmond Park, the moles, which are there most abundant, are invariably black ; but others of a different hue, have been taken in the wetter and more boggy places, where there is white sand beneath. In the same part, a white, or rather a creamcoloured mole has been caught. Mr. Jesse saw a grey one with an orange-coloured belly; and was assured by a mole-catcher, that he once caught a mole that was perfectly orange, except the head. In former times 
the skins of moles were much used, for the linings of winter garments, for the trimmings of several kinds of dress, and even for the coverlets of beds. The down or fur, which is as soft as the finest velvet, has been employed in the manufacture of hats; yet for these animals there is little or no sale. In some countries the flesh of the mole is eaten.

The aspect of this animal, on a hasty glance, is not pleasing : its feet appear thick and clumsy, and its eyes so very minute, that the ancients and some of the moderns thought it was blind; but when its structure is compare 1 with what it has to do, we are filled with admiration. It lives, be it observed, almost wholly beneath the surface of the ground, and feeds chiefly on worms and insects.

As therefore it is intended to burrow with great facility, its fore feet are beautifully adapted to this purpose : they appear like a pickaxe and shovel united; the long and powerful nails breaking the earth, while the broad sole of the foot pushes away that which is loose. All the force of the animal is required for these efforts; and bence the muscles of the fore feet are uncommonly large, while the hinder ones, not having such labour to perform, are smaller and much weaker.

The mole is directed solely to its prey by smell and 
sound; the proper organs are therefore specially prepared for its guidance. The tympanum of the ear is indeed remarkably large; but as the outer appendage so desirable to animals living above ground is here unnecessary, it is not present. As moreover, organs of vision are little needed by a creature dwelling in darkness, these appear in two little specks; and so well are they defended by the soft downy hair of the face, that no particle of earth can enter them to occasion distress. The district to which a mole confines itself may be termed its camp. Here, or hereabout, all its labours are pursued. The camp consists of the habitation or fortress, from which extends the high road by which the animal reaches the opposite end of its district, and of various galleries opening into the road, which it is continually extending in search of food.

The main dwelling is formed under a large hillock, which is always raised in a safe and defended situation ; under a bank, at the root of a tree, against the foundation of a wall, or in some similar place. The earth, of which the dome corering this curious habitation is composed, is made strong and solid, by being pressed and beaten in its formation. It contains a circular gallery within the base, which communicates with a smaller one above by four passages nearly equally dis- 
tant. The chamber is placed within the lower, and beneath the upper circular gallery, to which last it has access by three similar passages. From the chamber extends another road, the direction of which is at first downwards for several inches; it then rises again to open into the high road of the camp. From the outer circular gallery there are about nine other passages, the orifices of which are never found opposite to those which connect the outer with the inner and upper gallery; these extend to a greater or less distance; and are sai to return, each taking an irregular route, and opening into the high road at various distances from the fortress. Nothing can be more admirably calculated to secure the safety or retreat of the inhabitant; while the structure thus formed may rival those of the beaver, which have attained so much celebrity.

The principal road differs from all the other routes and excavations, both in its construction and use. It extends from the main dwelling to the end of the district in nearly a direct line, forming, in fact, the passage between the fortress and the different parts of the camp; and the alleys which lead to the spot where food is pursued, open into it on each side. It is larger than the body of the mole, but not large enough to allow of two passing each other. The walls are beaten by the 
frequent pressure of the animal's sides against them, until they become very smooth and compact. In fact, this road is chiefly formed by compressing the earth which surrounds it, rather than actual excavation. In some cases the same mole forms a second and even a third road; but this is generally done to extend its operations to a new and more productive district.

That the mole swiftly traverses its domain by means of this principal road, was satisfactorily proved by M. Le Court. Having found out the exact direction of the road, and that the animal was seeking its food on the ground at the furthest extremity from the fortress, he placed along its course at certain distances several pieces of straw, one end of which penetrated within the passage, while to the other was fixed a little flag of paper. He also introduced into the passage near the end, a horn, with the mouth-piece standing out of the ground. Then waiting till he was sure of the mole's presence at that part of the road, he blew into the horn ; when, in a moment, the little flags were successively thrown off, as the mole, in its rapid course towards its fortress, came in contact with the inner ends of the straws: and the spectators affirm, that the speed of the frightened mole was equal to that of a horse at full trot. 
The alleys or galleries are opened from the sides of the road, and generally incline a little downwards. These are formed, as has been stated, by throwing out the earth, while the high road is chiefly formed by its pressure. When one is opened, if a plentiful supply of food be found, the mole proceeds to form various ramifications from its extremity, throwing up fresh molehills as it advances in the pursuit of its prey; but if there be little, another is made at a different part of the road.

In lands newly sown, the surface of which is light and yielding after moderate rain, which has brought the earth-worms to the surface, the mole follows them, and pursues its chase along the outer layer of the soil, digging a shallow trench, and advancing in its work with great rapidity.

Prior to the setting in of winter, the mole is said to form a basin in a bed of clay, which will hold about a quart. Here, a great many worms are placed, and to prevent their escape, they are mutilated in part, but not killed. The worms are provision for the winter months. In some years there are much fewer of these basins than in others ; and from this, some who know the fact conclude, as they do when hedge-fruit, such as hips and haws, are comparatively scanty, that the winter will be mild. 
It was thought by James Hogg, well known as the Ettrick Shepherd, that farmers ought not to destroy moles; for he considered them of great use in spreading manure. He says, "If a hundred men and horses were employed on a pasture farm, say of from 1500 to 2000 acres, in raising and driving manure for a top dressing of that farm, they would not do it so neatly, equally, or effectually, as the natural number of moles on the farm would do it for themselves."

The Linnæan Transactions contain the following curious instance of the swimming of these animals :- "On visiting the Loch of Clunie, which I often did," says Mr. Arthur Bruce, "I observed in it a small island, at the distance of one hundred and eighty yards from the nearest land, measured to be so upon the ice. Upon the island, the Earl of Airly, the proprietor, has a castle and a small shrubbery. I remarked frequently the appearance of fresh mole roosts or hills. I for some time took them for those of the water mouse, and one day asked the gardener if it was so. 'No,' he said, ' it was the mole, and that he had caught one or two lately.' Five or six years before, he caught two in traps, and for two years after this he had observed none. But coming ashore one summer's evening in the dusk, he and the Earl of Airly's butler saw at a short 
distance upon the smooth water, some animal paddling towards the island. They soon closed with this feeble passenger, and found it to be the common mole, led by a most astonishing instinct from the castle hill, the nearest point of land, to take possession of this desert island. It had been, at the time of my visit, for the space or two years quite free from any subterraneous inhabitant ; but the mole has, for more than a year past, made its appearance again, and its operations I have since been witness to." 


\section{THE OX.}

MAN is more indebted to the ox than to any other animal. The general utility of this creature appears to have been discovered at a very early period, and hence we trace its domestication to a remote date. Jabal lived before the flood, and he is described as "the father of such as have cattle ;" and in every part of the earth the ox has been held in high estimation.

The writers of Greece are eager to secure the honour of training the ox, and yoking him to the plough, but they ascribe the work to many gods and goddesses, heroes, and other great men. With the Bible in our hands, we may trace it to the first descendants of our common father, one of whom was "a tiller of the ground." Even beyond them we must go, as not original instructors, but taught from above. Isaiah bears to us the charge and the inquiry, "Give ye ear, and hear my voice; hearken, and hear my speech. Doth the ploughman plough all day to sow? doth he open and break the clods of his ground? When he hath 
made plain the face thereof, doth he not cast abroad the fitches, and scatter the cummin, and cast in the principal wheat and the appointed barley and the rye in their place? For his God doth instruct him to discretion," Isaiah xxviii. 23-26. By direct aid from heaven to Adam, or his son Cain, men were taught to construct the plough, and to bend the neck of the ox to the yoke.

Nor was this any ordinary benefit. "Deprived of the aid of these useful animals," says Buffon, "the poor and the rich would alike have great difficulty to subsist. The earth in France would remain uncultivated; the fields, and even the gardens, would be dry and sterile. It is on the ox that the work of the country falls; he is the most useful domestic that the farmer possesses; and he performs all the labour of agriculture. In former ages he constituted the chief riches of mankind; and still he is the basis of the riches of those nations which only flourish and are supported by the cultivation of lands, and the number of their cattle. It is in these that all real wealth consists; every other kind, even silver and gold, are only arbitrary representations, which have no value, but that which is conferred upon them by the productions of the earth."

The earliest account we have of the ancient Britons 
shows that they had great numbers of cattle, that they did little in tillage, and lived on the flesh and milk of these animals. Such a mode of life suited the existing state of society. Divided, as the island was, into many petty sovereignties, no fixed property was secure, and that only was valuable which might be hurried away on the approach of an invader.

In the roving and uncertain life so long led by our ancestors, their cattle would sometimes stray and be lost. As the country was overgrown with forests, the beasts betook themselves to their recesses, became wild, and indeed ferocious. Sometimes, from their number, they were dangerous to the inhabitants of the neighbouring districts. As, however, civilisation advanced, these animals were more rarely seen, and at length almost disappeared.

The parent race of the ox is said to have been much larger than any of the present varieties. The Urus, in his wild state, at least, was an enormous and fierce animal. In almost every part of England, and of the Continent too, skulls have been found, far exceeding in bulk any now known, evidently belonging to cattle.

In the Earl of Tankerville's park, at Chillingham, near Berwick-upon-Tweed, there was lately a herd of wild cattle; these, with one or two other instances, afford 


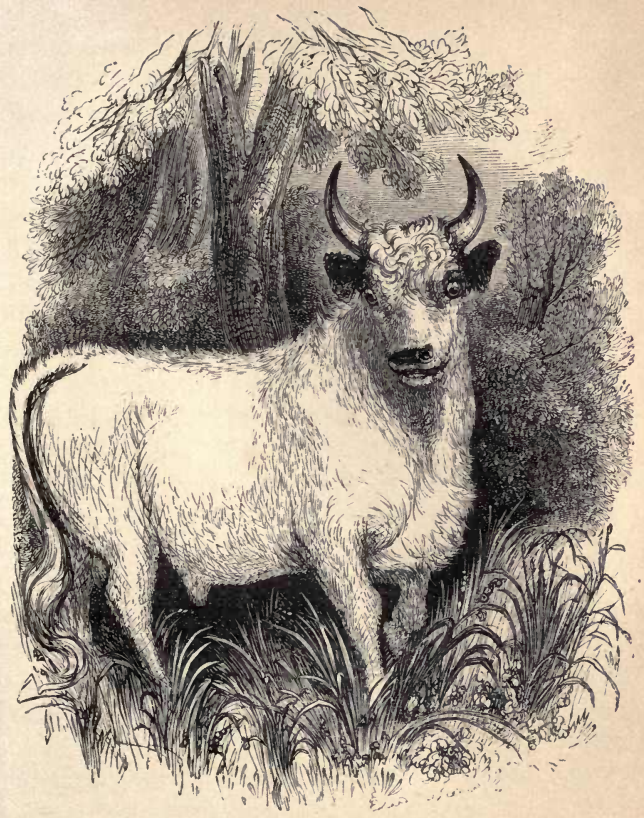

THE CHILLINGHAM BULL. 

probably the only remains of the true and genuine breed of that species, at present to be found in this kingdom. The following description is given of them by his lordship. "They have, in the first place, pre-eminently, all the characteristics of wild animals, with some peculiarities that are sometimes very curious and amusing. They hide their young, feed in the night, basking or sleeping during the day; they are fierce when pressed, but, generally speaking, very timorous, moving off on the appearance of any one, even at a great distance. Yet, this varies very much in different seasons of the year, according to the manner in which they are approached. In summer, I have been for several weeks at a time without getting a sight of them; they on the slightest appearance of any one, retiring into a wood, which serves them as a sanctuary. On the other hand, in winter, when coming down for food into the inner park, and being in contact with the people, they will let you almost come among them, particularly if on horseback. But then they have also a thousand peculiarities. They will be feeding sometimes quietly, when if any one appear suddenly near them, particularly coming down the wind, they will be struck with a sudden panic, and gallop off, running one after another, and never stopping till they get into their sanctuary. 
"It is observable of them, as of red deer, that they have a peculiar faculty of taking advantage of the irregularities of the ground, so that on being disturbed they may traverse the whole park, and yet you hardly get a sight of them. Their usual mode of retreat is to get up slowly, set off in a walk, then a trot, and seldom begin to gallop till they have put the ground between you and them in the manner that I have described. In form, they are beautifully shaped, short legs, straight black horns of a very fine texture, thin skin, so that some of the bulls appear of a cream colour ; and they have a peculiar cry, more like that of a wild beast than that of ordinary cattle.

"When they come down into the lower part of the park, which they do at stated hours, they move like a regiment of cavalry in single files, the bulls leading the van, as in retreat it is the bulls that bring up the rear. Lord Ossulton was witness to a curious way in whích they took possession, as it were, of some new pasture recently laid open to them. It was in the evening, about sunset. They began by lining the front of a small wood, which seemed quite alive with them, when all of a sudden they made a dash forward altogether in a line, and charging close by him across the plain, they then spread out, and after a little time began feeding." 
Mr. Cole, the keeper, adds the following statements from his own observation. "There are about eighty in the herd, comprising twenty-five bulls, forty cows, and fifteen steers of various ages. The eyes, eye-lashes, and tips of the horns alone are black. The muzzle is brown, the inside of the ears are red and brown, and all the rest of the animal white. Even the bulls have no manes, but a little coarse hair on their neck. They fight for supremacy until a few of the most powerful subdue the others, and the mastery is no longer disputed. When two bulls are separated by accident, they fight when they meet, although friendly before, and do so till they become friends again."

The late Mr. Bailey of Chillingham found a calf two or three days old, very poor and weak. On stroking it, it retired a few paces, and then bolted at him with all its force,-a strong fact in support of the opinion of the natural wildness of these animals; -he stepped out of its way, and it fell down, when the whole flock came to its rescue, and forced him to retreat. These wild cattle do not often die from disease, but they are seldom allowed to live more than eight or nine years, at which period, "they begin to go back." When slaughtered, they weigh from thirty-eight to forty-two stones.

One was caught and kept, and became as tame as the 
domestic ox, and thrived as well as any short-horned steer could do; and in its prime, was computed to weigh sixty-five stones. They are shy in summer, but tame in winter, and will eat from a fold, although they will not taste turnips. When one of the herd becomes weak or feeble, the rest sometimes set upon it, and gore it to death. At the end of the last century, similar cattle existed at Burton Constable, Yorkshire, and at Dunlary in Dumfrieshire, but these are now extinct. From the absence of all recent notice of these animals, there appears to be little doubt but that they are genuine descendants of the wild cattle of the ancient Caledonian forests.

Britain, though surrounded by the ocean, has often been overrun by ferocious invaders. As the people retreated before their foes, they took with them, their cattle, the chief part of their property. They did this when they retired to the fortresses of North Devon and Cornwall, or the mountains of Wales, or when they sought shelter in the wealds of Sussex, and there they were anxious to preserve these animals. The ancient breed thus sustained, experienced some change, particularly in bulk, from difference of climate. In Devon, Sussex, Wales, and Scotland, the cattle have been the same from time immemorial; while on the eastern coast, 
and through every other district of Britain, they exhibit a great variety, yet are generally conformed to the soil and the climate.

The breeds of cattle, as they are now found in Great Britain, have been classed according to the comparative size of their horns. The long horns, originally, so far as this country is concerned, from Lancashire, but much improved in Leicestershire, appear through the greater part of the midland counties. The short horns, originally from East York, and improved in Durham, are mostly found in Lincolnshire and the northern counties, and many of them, wherever much attention is given to the dairy. The middle horns are a distinct and valuable breed, inhabiting principally the north of Devon, the east of Sussex, Herefordshire, and Gloucestershire : The polled, or hornless cattle, prevail in Galloway, whence they were first derived, and in Norfolk and Suffolk; and the little Alderney cow, with her crumpled horn, is found in gentlemen's parks and pleasure-grounds very generally.

The management of cattle sometimes calls for much activity. Their summer pasturing in distant glens, and on their enclosing mountains, is practised in the Highlands of Scotland. Mrs. Grant describes this "flitting" of the people with her usual animation. "This 
changing of their residence so often as they did in summer, from one bothy (booth) or glen to another," she remarks, "gave a romantic peculiarity to their turn of thought and language. Their manner of life, in fact, wanted nothing but the shades of palm, the olives, the vines, and the fervid sun of the East, to resemble the patriarchal one. Yet, as they must carry their beds, food, and utensils, the housewife who furnishes and divides these matters, has enough to do, when her shepherd is in one glen, and her dairy-maid in another, with her milk cattle. Not to mention some of the children, who are marched off to the glen, as a discipline, to inure them early to hardiness and simplicity of life.

"As I find myself," continues the same writer, " in the humour of journalizing and particularizing, I shall, between fancy and memory, sketch out the diary of one July Monday. I mention Monday, being the day that all dwellers in the glens come down for the supplies. Then, at four o'clock, Donald arrives with a horse loaded with butter, cheese, and milk. The former I must weigh instantly. He only asks an additional blanket for the children, a covering for himself, two milk-tubs, a cog, and another spoon, because little Peter threw one of the set into the burn; two stone of meal, a quart of salt, and two pounds of flax for the spinners, 
for the grass continues so good that they will stay a week longer. He brings the intelligence of the old sow's being the joyful mother of a dozen pigs, and requests something to feed her with. All this must be ready in an hour : before the conclusion of which, comes Ronald from the high hills, where our sheep and young horses are all summer, and only desires meal, salt, and women with shears to clip the lambs, and tar to smear them. He informs me that the black mare has a foal, a very fine one; but she is very low, and I must instantly send one to bring her to the meadows, before he departs. The tenants who do us services come; they are going to stay two days in the oak wood, cutting timber for our new byre, and must have a competent provision of bread, cheese, and ale for the time they stay."

The bull is commonly considered a formidable animal, and it is necessary to be cautious when one comes in our way. "Talking of a mischievous bull," says Sir Walter Scott to a friend, "puts me in mind of a case which I witnessed many years ago in Edinburgh. I was proceeding from the Old to the New Town by the Earthen Mound, at the head of which I was led for a few minutes to look at a bull that had got into an enclosure there, after the unmerciful butcher- 
lads had driven it fairly mad. The crowd that gathered on the outside of the fence increased the brute's fierceness. At last they began to cast ropes over its horns, and around its neck, thereby to pull it to a stronghold, that it might be slain in the place where it was, which drove it to its most desperate fury. Its eyes now glared madness; there were handfuls of foam flying from its mouth ; with its fore-feet it pawed the ground, throwing up lumps of earth as high as the adjoining houses, and it bellowed so as to make one quake. It was anything but an agreeable sight, so I moved away homewards. But before I got to the foot of the Mound, an alarming shout caused me to look back, when I perceived the animal at no great distance behind me coming on with all its rage. I had just time torspring to the top of the wall that lined the footpath, and to behold its future progress.

"I shudder at this hour when I think of what immediately I saw. Among the people that were near me and in jeopardy, was a young lady, and she wore a red mantle, which is a very offensive colour to many of the brute creation. And as I did, she also made for the wall, but had neither time nor strength to gain its top ere the infuriated animal drove towards her. She turned her back, however, to the inaccessible eminence, as if to see 
the full extent of her fate, and then stood as nailed to it, save only her arms, which she threw aloft in her despair, which would have been as fragile in her defence as a rotten reed. Her tender body would have been nothing against a force that could have broken bars of brass, and horns that might have transfixed an animal of its own size. As I have said, directly towards the unprotected young lady, the bull drove forward; with intentest eyes he came on, he mistook his mark not an inch; for as the multitude behind him yelled their horror, he dashed with prodigious strength and madness against her." Most providential was her deliverance, for, Sir Walter adds : "The dear young woman escaped unhurt and untouched. The terrific animal struck at her so accurately, that a horn smote the dead wall on either side, thus embracing, but from their great length shielding, her person from even the slightest danger. But the staunch wall stood the tremendous thrust, and sent back with rebounding force to a great distance, the huge and terrible brute, throwing him prostrate never to rise again, for numberless destructive weapons were plunged into him ere he had time to recover from the recoil."

Sir Walter describes this madness to have been occasioned by the wanton violence of its drivers and pur- 
suers, a common cause of it ; and that these animals are greatly affected by their ordinary treatment is beyond dispute. Mr. Bakewell has obtained much celebrity for his management of cattle, and he is always very gentle. All his bulls, therefore, stand still in the field to be examined ; they are driven home, or from one field to another by a little switch; he or his men walk by their side, and guide them with the stick wherever they please, and to this method they are accustomed from being calves. A lad, with a stick three feet long, and the size of his finger, will conduct a bull from other bulls, and his cows from one end of the farm to the other. The mischief often done by bulls is therefore owing to total neglect, or contrary practices.

It appears, indeed, that cattle, like other animals, are the creatures of circumstances. Nothing commonly occurs to call forth and stimulate sagacity; were it otherwise, even this interesting quality would doubtless be displayed. The conclusion is warranted by such cases as the following: A gentleman near Laggan had a bull which grazed with the cows in the open meadows, and as fences are scarcely known in that part, a boy was kept to watch, lest the cattle should trespass on the neighbouring fields and destroy the corn. But the boy was fat and drowsy; he was often found asleep, 
and was of course chastised whenever the cattle went astray. This led him to keep a long switch, and to avenge himself with an unsparing hand if any of them crossed the boundary. The bull, too, seemed to have observed with concern this consequence of wandering, and setting them a good example by never straying, he placed himself before the cows in a threatening attitude whenever they approached the bounds, and as he had no horns, he used to strike them with his large forehead, and thus punish them severely if any of them transgressed. At length, his watchfulness and honesty were so apparent, that the boy was employed in other business, without fear that the cattle would misbehave in his absence.

Of the sympathy displayed by cattle towards others of their kind in distress, the following is an interesting proof, from Captain Cochrane's Travels in Columbia : "I was suddenly aroused by a most terrific noise, a mixture of loud roarings and of deep moans, which had the most appalling effect at so late an hour. I immediately went out attended by the Indians, when I found close to the rancha a large herd of bullocks collected from the surrounding country; they had encompassed the spot where a bullock had been killed in the morning, and they appeared to be in the greatest state of 
grief and rage ; they roared, they moaned, they tore the ground with their feet, and bellowed the most hideous chorus that can be imagined, and it was with the greatest difficulty they could be driven away by men and dogs. Since then, I have observed the same scene by daylight, and seen large tears rolling down their cheeks. Is it instinct merely? or, does something nearer to reason tell them by the blood, that one of their companions has been butchered? I certainly never wish again to view so painful a sight : they actually appeared to be reproaching us."

The Devon ox is very good tempered and docile; it is also unusually active, and displays great strength and perseverance. Four of them are despribed to be equal in work to three horses, and will trot along up to six miles an hour with empty wagons in harrest. Mr. Youatt says :- "There is a peculiarity in driving the ox team, which is very pleasing to the stranger, and the remembrance of which, connected with his early days, the native does not soon lose. A man and a boy attend each team; the boy chants that which can scarcely be regarded as any distinct tune, but which is a very pleasing succession of sounds, resembling the countertenor in the service of a cathedral. He sings away with unwearied lungs, as he trudges along almost from 
morning to night, while every now and then the ploughman, as he directs the movement of the team, puts in his lower notes, but in perfect concord. When the traveller stops in one of the Devonshire valleys, and hears this simple music from the drivers of the ploughs on the slope of the hill on either side, he experiences a pleasure which this operation of husbandry could scarcely be supposed to be capable of affording. This chanting is said to animate the oxen somewhat in the same way as the musical bells which are so prevalent in the same county. Certainly, the oxen move along with an agility that could scarcely be expected from cattle; and the team may be watched a long while without one harsh word being heard, or the goad or the whip applied. The opponents of ox-husbandry should visit the valleys of North or South Devon, to see what this animal is capable of performing, and how he performs it."

In South Africa the ox displays no common intelligence. The Hottentot and the Caffre well know his sagacity. While the sheep enjoy their pastures, he stands and gazes behind them; yet, attentive to the looks of his master, he flies round the field to keep those who are straying within proper limits. Nor is this all ; he shows no mercy to the plunderers of the flock, and is even made to combat with the enemies of the people. 
The backely, as he is called, has his reward. He lives in the same hut as his master, and by long habit gains an affection for him. When the animal dies, a new one is chosen in his place. He is then joined with the veterans of his own kind, from whom he learns his art, becomes social and diligent, and is taken into human protection and friendship for life.

\section{THE COW.}

Of all animals, except man' according to Buffon, the cow appears to be most generally known. Abraham brought a calf, tender and good, and milk for the angels, under the oak at Mamre; and numerous passages show how generally acceptable and agreeable were such offerings. When, too, Jehovah was about to make a covenant with that patriarch, an heifer was one of the appointed victims.

In the services of the Israelites, there was one sacrifice which differed from all others. A red heifer was slain, not in the court of the tabernacle, but without the camp; and all the fat, the greater part of the blood, 
and the skin and carcass, were burned. A portion of the blood was, however, to be sprinkled by the priest directly before the tabernacle of the congregation, and the ashes of the animal were to be laid up for " a water of separation," "a purification for sin." How impressive was this type! It spoke of that pollution of which we all partake ; it pointed to Christ, who bore our sins, and suffered without Jerusalem by the hands of the Romans; and it announced that cleansing power which we must experience if we would now engage acceptably in the service of God, and be prepared for His everlasting kingdom. To this service, and to another of a similar character, the Apostle alludes when he says, "If the blood of bulls and of goats, and the ashes of an heifer sprinkling the unclean, sanctifieth to the purifying of the flesh: how much more shall the blood of Christ, who through the eternal Spirit offered himself without spot to God, purge your conscience from dead works to serve the living God?" Hebrews ix. 13, 14. Well then may we adopt the language of Cowper :-

" Israel, in ancient days,

Not only had a view

Of Sinai in a blaze,

But had the Gospel too:

The types and shadows were a glass,

In which they saw a Saviour's face. 


\section{" Jesus, I love to trace}

Throughout the sacred page,

The riches of thy grace,

The same in every age;

Oh grant that I may faithful be,

To clearer light vouchsafed to me !"

The animal which has suggested these considerations, has been for ages of great value to people in very different circumstances. Its nature seems equally capable of the rigours of heat and cold; it is an inhabitant of the frozen fields of Iceland, as well as of the burning deserts of Asia. "It seems," says Buffon, "an ancient inmate in every climate; domestic and tame in those countries which have been, ${ }_{1}$ civilized; savage and wild in the countries which are less peopled, but capable of being made useful in all; able to defend itself in a state of nature against the most powerful enemy of the forest, and only subordinate to man, whose force it has experienced, and whose aid it at last seems to require. However wild the calves are which are taken from the dam in a savage state, either in Africa or Asia, they soon become humble, patient, and familiar; and man may be considered, in these countries, as almost helpless without their assistance."

To the milk of the cow we are generally indebted for a most nutritious and wholesome aliment. In a Wiltshire 
cheese-farm, by three o'clock on a summer's morning the cows are in the yard, and the dairy-women at work. The milkers are generally the wives and daughters of the farm labourers, being hired for this special purpose. The morning's milking over, these women retire to their other occupations, many of them being employed elsewhere in different labours; and they do not return till about four o'clock in the afternoon, that being, in summer, the general hour for the evening's milking.

After milk has stood a few hours, cream rises to the surface. This is skimmed off for several purposes, but chiefly to be made into butter, which is done by beating it in a vessel called a churn. This process requires to be very carefully performed. When freed from the remaining milk, it is called fresh butter, and to preserve it sweet, it requires to be salted, which is usually done with common salt. The best butter is that made during the summer, but its appearance and flavour are given to butter made in winter.

The dairies and buildings attached to them are larger and more commodious in Wiltshire than in any other county. Here no butter is sold: a portion of the milk sufficient to produce butter for family use is taken and set for cream; but the skim milk is never added to that from which the cheese is made. 
Nearly all the cheese consumed in England is made from the milk of cows, which is curdled by mixture with a sweet acid called rennet; and the curd thus formed, when cleared of the whey, or watery part of the milk, is collected together, pressed, and dried for use.

Cheshire is famous for its cheese ; and much, of rich and excellent quality, is made in Gloucestershire and Wiltshire. The principal of all the English kinds, is that called Stilton, which was first made, not at the place so named, but at Wimondham in Leicestershire. Mr. Paulet, who resided there, a relation of Cooper Thornhill, who formerly kept the Bell Inn at Stilton in Huntingdonshire, on what was called the great north road, "had cream-cheese, which being of a very fine quality was in great request," and was sold at the cost of half-a-crown a pound. As the place of its manufacture was not publicly known, it was called Stilton cheese. At length, this was discovered; the art of producing it was learned by other persons, and it was soon made at the rate of many tons in a year in the country around.

On the various uses to which the flesh, skin, bones, horns, and fat of oxen and cows are appropriated, we cannot dwell, and will therefore only point out a few of the qualities which the latter discover. Cows have a 
very strong affection for their young. One of these animals, whose calf was left at the kead keeper's yard in Bushey Park, where King William Iv. long lived as Duke of Clarence, was driven from thence, and sold in Smithfield market. Yet she made her way through the intricacies and obstacles of London, and traversed twelve miles of road to reach her calf, and was found at the gate of the yard early the next morning. She must also have watched when the park gates were opened, and seized the opportunity to enter.

Cows are not wanting in sympathy for others when in trouble. One, for instance, was observed some time since, at which a dog was barking, when the others in the same meadow turned round at his noise, and perceiving the assailant, walked slowly up to the cow as if to assist her. At another time, when a similar attack was made, the cow bent her head to present her horns, but the dog persisted and pursued her, while she, intimidated, retreated. The other cows at a distance first raised their heads to listen, then turned to the sound, and seeing their companion still distressed by the dog, they became much excited. One went towards her, then two others ; afterwards another galloped furiously up to them, and six formed into a semicircle to protect her. Still the dog renewed his attack, when one of the cows 
left its place, and ran deliberately at him. Quitting now the object of his first assault, and seeing that the other continued to rush onwards, he seemed to think that he was in danger, and moved away silently and slowly. The excited cow, however, went after him, until, as he quickened his pace, she galloped as fast as she could, as if intent on his punishment; but he outran her, and escaped. "The following little anecdote," Mr. Jesse says, "will show the gratitude and recollection of the kindness shown to an animal. A young lady brought up a calf whose mother bad died soon after it was born. She made a pet of it; but, when it became an heifer, for some reason, it was parted with, and she lost sight of it for about two years. At the end of that time, as she was walking with a friend in a lane, she met some cows, when one of them left the herd and came up to her, showing evident symptoms of pleasure in seeing her. She immediately knew and patted her old acquaintance, who, after being satisfied by these marks of her favour that the recognition was mutual, quietly turned away and joined her companions." 


\section{THE SHREW.}

THE common shrew is like the weasel in colour, and the mole in its head. It is sometimes called the shrew mouse, from the little creature it also much resembles. It frequents dry situations, feeding on insects and worms ; in the pursuit of which, its snout enables it to grub amongst the closest herbage, or under the surface of the soil, for which it is well adapted by its form, and by its soft, short, velvety coat. Its nest, which consists of soft herbage, is made in any hole on the ground, or in a bank: it is covered over at the top, and is entered at the side. The shrill piercing cry of this animal may frequently be heard in spring and summer, from the spots it loves to frequent. In autumn numbers of them are found dead along the pathways and by the sides of banks; but the cause of so extensive a mortality is not known. Shrews, with bats, seals, and mice, are the groups in which many discoveries will yet most probably be made. 


\section{THE WATER-SHREW.}

The water-shrew, while generally like the former species, has certain peculiarities. The addition to the sides of the toes, the greater breadth of the feet, and the fringe of hairs on the upper surface of the tail, show that it requires the use of oars and a rudder, and that, while the food consists of insects, it is to be obtained in the water.

The following very interesting account of its habits is given by Mr. Dovaston. "On a delicious evening, far in April, 1825, a little before sunset, strolling in my orchard beside a pool, and looking into the clear water for insects I expected about that time to come out, I was surprised by seeing what I momentarily imagined to be a Ditiscus marginalis, or some very large beetle, dart with rapid motion, and suddenly disappear. Laying myself down cautiously and motionless on the grass, I soon, to my delight and wonder, observed it was a mouse. I repeatedly marked it glide from the bank under water, and bury itself in the mass of leaves at the bottom :-I mean the leaves that had fallen off the trees in autumn, and which lay very thick over the mud. It very shortly returned, and entered the bank, 
occasionally putting its long sharp nose out of the water, and paddling close to the edge. This it repeated at frequent intervals, from place to place, seldom going more than two yards from the side, and always returning in about half a minute. I presume it sought and obtained some insect or food among the rubbish and leaves, and retired to consume it. Sometimes it would run a little on the surface, and sometimes timidly and hastily come ashore, but with the greatest caution, and instantly plunged in again. During the whole sweet spring of that fine year, I constantly visited my new acquaintance. When under water he looks grey, on account of the pearly cluster of minute air-bubbles that adhere to his fur, and bespangle him all over. $\mathrm{He}$ swims very rapidly, and, though he appears to dart, his very nimble wriggle is clearly discernible." 


\section{THE BADGER.}

THE common length of the badger is about three feet. Its body and legs are thick; the latter are very short; the claws of the fore feet are long, strong, and straight, and fit for butrowing. The eyes are placed in a black stripe of hair which begins behind the ears, and runs tapering to the nose. The back, sides, and tail are grey; the lower parts and limbs entirely black. This animal is found in several of the woody districts of England, as well as in nearly all the temperate parts of Europe.

The favourite haunts of this animal are obscure and gloomy : it retires to the deepest recesses of woods, or to thick coppices covering the sides of hills, and there forms its abode. Its structure fits it for such work; and with its long and powerful claws it digs for itself a deep and well-formed dwelling, consisting of more than one apartment, and having only one entrance. Here it sleeps during the greater part of the day, coming 


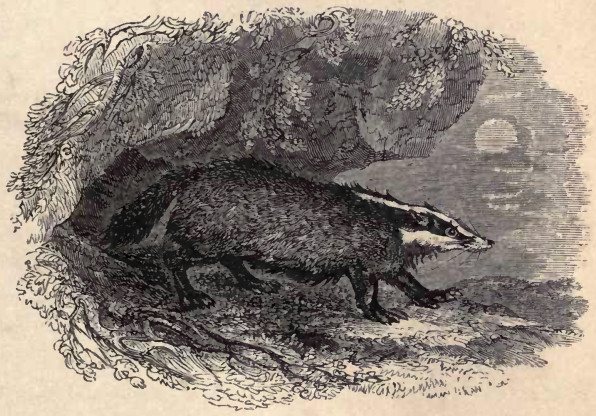

THE BADGER, 


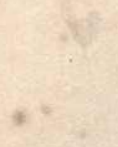


abroad only for a short period in the evening or night to seek its food, consisting indifferently of various roots, earth-nuts, beech-mast, fruits, the eggs of birds, some of the smaller quadrupeds, frogs, and insects.

The time for preparing to catch badgers is night, when they are abroad in pursuit of food. For this purpose, sacks are fastened into the mouth of their burrows in the ground, and the animals are then hunted home from the neighbouring fields by dogs. On entering their usual places of retreat, hoping to escape from their foes, they are instantly seized, and tied up in sacks by the men, who are ready to do so. Steel traps are sometimes placed in the haunts of badgers, and by this means also they are caught.

When taken young, the badger may be easily and completely tamed. Of this, the eminent naturalist, $\mathrm{Mr}$. Bell, gives the following instance:- "I had one for a considerable time, which was sent to me by my valued old friend, James Buckland, Esq., of Shaftesbury, who had obtained it from a cottager in the neighbourhood, whose children Mr. Buckland accidentally saw playing with the badger as familiarly as they would with a puppy. He found that the animal had been taken when very young, and had been brought up as the playmate of the children: it had, however, become rather too rough in 
its fondness, and the poor man was willing to part with it. It thus came into my possession, and soon became a great favourite, showing too, on its part, great attachment to me and to the household. It followed me like a dog, yelping and barking with a peculiar sharp cry, when he found himself shut out of the room in which I happened to be sitting. He was accustomed to come into the dining-room during dinner, of which he was generally permitted to partake, and he always ate his morsels in a very orderly manner. He was, in fact, an affectionate, gentle, good-tempered fellow, and very cleanly withal."

As a proof of the strong affection of the badger, the following circumstance was related by a gentleman residing at Chateau de Vernours. Two persons were on a journey, and passing through a hollow way, a dog which was with them started a badger, which he attacked and pursued till the animal took shelter in a burrow under a tree. With some pains he was hunted out and killed. Being a few miles from a village called Chapellatiere, they agreed to drag him thither, as the commune gave a reward for every one which was destroyed; besides, they proposed selling the skin, as badgers' hair furnishes excellent hair for painters. Not having a rope, they twisted some twigs, and drew him along the road by 
turns. They had not proceeded far, when they heard the cry of an animal in seeming distress, and stopped to listen whence it proceeded, when another badger approached them slowly. They at first threw stones at it; notwithstanding which, it drew near, came up to the dead animal, began to lick it, and continued its mournful cry. The men, surprised at this, desisted from offering any farther injury to it, and again drew the dead one along as before; when the living badger, determined not to quit its dead companion, lay down on it, taking it gently by one ear, and in that manner was drawn into the midst of the village,-nor could dogs, boys, or men induce it to quit the situation by any means; and to their shame, be it said, they had the inhumanity to kill the poor animal, and afterwards to burn it, declaring it could be no other than a witch! 


\section{THE OTTER.}

THe body of this creature usually measures about two feet, besides the tail, which is nearly sixteen inches in length. The legs are short, strong, and capable of acting like fins. Each foot has five webbed toes, provided with strong sharp nails. The fur is of a deep and blackish brown, with two small spots on each side of the nose, and another under the chin. The eyes are large, bright, and so placed in the head that the animal can see any object that is above it.

The Otter does not excavate a habitation, as has frequently been stated, but avails itself of any hollow, preferring such as are beneath the overhanging roots of trees which grow on the banks of rivers, or any other secure and concealed hole near its fishing haunt. In certain cases, however, it fixes its retreat at some distance from the water, and when driven by a scanty supply of fish, it has been known to resort far inland to the neighbourhood of the farm-yard, that there it may attack lambs, sucking-pigs, and poultry. 


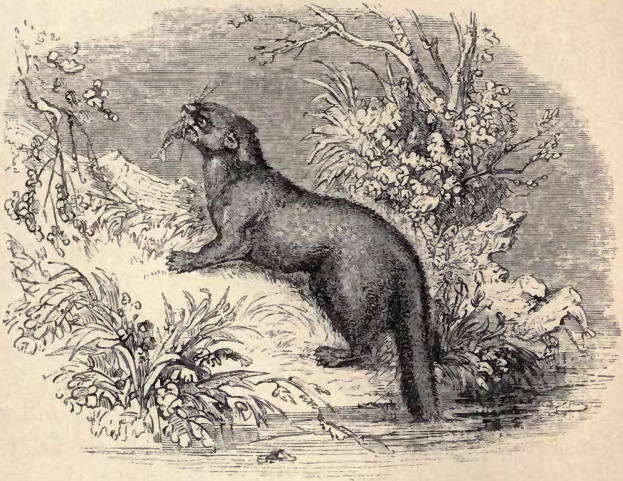

THE OTTER. 
In Scotland, the opinion is entertained by some ignorant persons, that there is an otter of a larger size than usual, and spotted with white, which is a leader or king of these animals. They believe that it is never killed without the sudden death of a man or of some animal at the same instant, that its skin is endowed with great virtue as an antidote against infection, preserves a warrior from wounds, and ensures the mariner from all disasters on the sea. Such remains of ignorance and superstition are truly lamentable. They awfully degrade and grievously enfeeble the mind, while they keep it away from Him, with whom alone it is, to give peace or trouble-to kill or make alive. The progress of sound and scriptural knowledge is therefore to be ardently desired,-the knowledge that can deliver man from the thraldom of the worst evils, by leading him to the footstool of the God of truth.

In the northern parts of Scotland, otters frequent the sea, and extend their rambles to a considerable distance from the shore. In the summer, and when the weather will permit, this creature occupies a retired and quiet station where the land stretches into the ocean. It swims low in the water, and will go a mile or more after its prey. Fishes seem to have an instinctive dread of it, for it has been seen to collect into a shoal a vast number of trouts 
BRITISH QUADRUPEDS.

in a river, and to drive them before it until the greater part have thrown themselves on the bank.

Referring to these habits, Somerville says :-

"Seas have their sharks;

Rivers and ponds enclose the ravenous pike;

He in his turn, becomes a prey; on him

The amphibious otter feasts. Just is his fate

Deserved; but tyrants know no bounds; nor spears,

That bristle on its back, defend the perch

From his wide greddy jaws; nor burnished mail

The yellow carp; nor all his arts can save

The insinuating eel, that hides his head

Beneath the slimy mud; nor yet escapes

The crimson-spotted trout, the river's pride, and beauty of the stream."

There is an Irish otter which differs, in some respects, from that which is common in England. It is to a considerable extent a marine animal, being found chiefly on the coast of the county of Antrim, living in hollows and caverns formed by the scattered masses of the basaltic columns of that coast, and constantly betaking itself to the sea when alarmed or hunted. It feeds principally on the salmon; and as it is injurious to the fishery, a reward is given for its destruction. There are, therefore, many persons who are employed in hunting it, obtaining a livelihood by the premium offered, and by the sale of its skin.

In reference to a young otter, Izaak Walton repre- 
sents his angler as saying to a sportsman engaged in an otter hunt, "I pray, sir, save me one, and I'll try if I can make her tame, as I know an ingenious gentleman in Leicestershire, Mr. Nicholas Seagrave, has done; who hath not only made her tame, but to catch fish, and do many other things of much pleasure." Such is indeed far from being an uncommon instance. In one case, an otter was known to take eight or ten salmon in a day.

One of the Asiatic species, it appears, may be made similarly useful. "We passed, to my surprise," says Bishop Heber, " a row of no less than nine or ten large and very beautiful otters, tethered with straw collars and long strings to bamboo stakes, on the banks of the Matta Colly. Some were swimming about at the full extent of their strings, or lying half in and half out of the water ; others were rolling themselves in the sun on the sandy bank, uttering a shrill, whistling noise, as if in play. I was told that most of the fishermen in this neighbourhood kept one or more of these animals, who were almost as tame as dogs, and of great use in fishing; sometimes driving the shoals into the nets, sometimes bringing out the larger fish with their teeth. I was much pleased and interested with the sight. It has always been a fancy of mine that the poor creatures 
whom we waste and persecute to death, for no cause but the gratification of our cruelty, might, by reasonable treatment, be made the source of abundant amusement and advantage to us."

The affection of these animals for their offspring is indisputable. Professor Steller says, "Often have I spared the lives of the female otters, whose young ones I took away. They expressed their sorrow by crying like hurtan beings, and followed me as I was carrying off their young, while they called to them for aid, with a tone of voice very much resembling the cry of children. When I sat down in the snow, they came quite close to me, and attempted to carry off their young.

" On one occasion, when I had deprived an otter of her progeny, I returned to the place eight days after, and found the female sitting by the river, listless and desponding; she suffered me to kill her on the spot, without making any attempt to escape. On skinning her, I found she had quite wasted away from sorrow for the loss of her young.

"Another time, I saw at some distance from me an old female otter sleeping by the side of a young one about a year old. As soon as the mother perceived us, she awoke the young one, and enticed him to betake 
himself to the river; but as he did not take the hint, and seemed inclined to prolong his sleep, she took him up in her fore paws, and plunged him into the water." The sight of otters feeding, as they may be seen in the Zoological Gardens in the Regent's Park, is very interesting; the clear water allowing the movements of the fish, and those of the pursuer, which gracefully dives and glides along as if without effort, to be distinctly traced. 


\section{THE DOG.}

All the canine races are supposed to be derived from the wolf. The structure of these animals is identical, or nearly so. It is evident that the dog must have come from a creature capable of the highest degree of domestication, and of great affection for mankind, which, says Mr. Bell, has been abundantly proved of the wolf. Dogs having returned to a wild state, and continued in that condition through many generations, exhibit, moreover, characters which approximate more and more to those of the wolf, in proportion as the influence of domestication ceases to act.

The eminent naturalist just mentioned refers, in illustration of his views, to a wolf described by M. Frederick Cuvier. This animal was brought up as a young dog; he became familiar with every person he was in the habit of seeing, and, in particular, followed his master everywhere, displaying evident chagrin at his absence, obeying his voice, and showing a submission 
scarcely differing at all from that of a thoroughly domesticated dog.

His master, being obliged to be absent for a time, gave his pet to the royal menagerie, where the animal, confined in a den, remained disconsolate, and would scarcely take his food; but at length his health was restored, he became attached to his keepers, and seemed to have forgotten all his former affection. After eighteen months, his master returned; at the first word he uttered, the wolf, who had not perceived him among the crowd, recognized him, exhibited the most lively joy, and, being set at liberty, lavished on his old friend the most affectionate caresses, just as the most attached dog would have done after the absence of a few days.

A second separation was followed by similar proofs of sorrow, which, however, again yielded to time. Three years had passed, and the wolf was living happily with a dog which had been placed with him, when his master again returned, and again the long lost but still remembered voice was instantly replied to by the most impatient cries, which were redoubled when he was at liberty. Rushing to his master, he threw his fore-feet on his shoulders, licking his face with every mark of the most lively joy, and menacing his keepers who offered to remove him, and towards whom, not a moment 
before, he had been showing every mark of fondness.

A third separation, however, seemed to be too much for this faithful animal's temper; he became gloomy and desponding, refused his food, and for a long time his life appeared in danger. His health, however, returned; but he no longer suffered the caresses of any but his keepers, and towards strangers was as savage as the rest of his species. "Now if," adds Mr. Bell, "we find that the mere education of a young wolf, taken from its parents in a wild state, could so far change its natural disposition, and render it so fond, so intelligent, so grateful as this, what may we not expect from the successive transmission of improvement by the culture and training of a whole race for ages?"

We have no means of deciding, however, when the dog was first trained. It was said during the sojourn of Israel in Egypt, that "against them a dog should not move his tongue ;" from which it would appear, that these animals were kept in a domesticated state in the families of the Egyptians. This is the earliest reference we have to them. It may seem strange that the dog should almost uniformly be spoken of in Scripture, in such terms as to show that it was held in great contempt among the Jewish people. But it is probable, 
that it appears to disadvantage under the law of Moses, and, consequently, in the language and feelings of the people, because it was conspicuous among the divinities of ancient Egypt.

The Turks reckon the $d o g$ an unclean and filthy creature, and drive him from their houses. Among them, therefore, these animals commonly do not belong to any particular owners, but range the streets and districts, and do not guard particular houses. Such, indeed, is their common treatment in the East; even in Egypt, they are now as much abhorred as they once were venerated.

That the dog appears of a very different character in such circumstances, is placed beyond dispute. According to Poiret, this animal loses in Barbary, as in the East in general, the greater part, or all of his attractive qualities. Among the Arabs his appearance is disagreeable, and his look savage. The Moors grant him a corner in their tent, but that is all. They never caress him, or throw him any thing to eat. No wonder, then, he is indifferent to his master. Often, indeed, he has none, and his savageness is the natural consequence of neglect.

If, however, it is apparent that dogs have been disesteemed and ill-treated, there are proofs, even from 
remote periods of antiquity, that the noble qualities of these creatures, as displayed in more favourable circumstances, were sometimes appreciated. While most other animals fear man as an enemy, here appears one that regards him as a companion, and even after longcontinued absence remembers him as a friend. Nearly three thousand years ago, Homer celebrated the attachment of Argus, the dog of Ulysses. Aged, and left neglected in the public ways, he recognized his master after the lapse of twenty years, strove in vain to crawl and kiss his feet, and died while gazing on the object of his affection. From that time to the present, the value of the dog has been very commonly acknowledged by all ranks of the people. And no wonder, when instances of canine sagacity and fidelity are so numerous. They abound in all our books of Natural History; but some of them must now be given, as we consider dogs of different species, avoiding those which are most likely to be known to many of the readers of this volume.

\section{THE MASTIFF.}

This powerful dog is considered as belonging to a truly English breed. The ground colour is generally a 
dirty white, with numerous dark hairs all over the body, and transverse stripes of a darker hue. The mastiff is a large animal, better fitted for training than the bulldog, and, consequently, for domestic purposes. He is frequently known to protect his master's house and property by menaces only; even when a stranger is within his power he is not excited to violence, unless an imprudent perseverance should render it necessary. In such cases, a mastiff has been known to pull a man down, and to stand over him, without hurting him, a considerable time, until the appearance of his master.

\section{THE SHEPHERD'S DOG.}

"In instinct and sagacity," says Bingley, " the shepherd's dog is, perhaps, superior to all others; for while the rest require great care and attention to train them to labour, this animal applies himself without any difficulty to that to which he is usually appropriated. His usefulness alone has been the recommendation to preserve the species; since no dog can go through a more extensive variety of duty, nor does any one perform more services to his master, than this. In wild 
tracts of country, that are solely appropriated to the feeding of sheep and cattle, immense flocks may be seen, ranging over the wilds, apparently without control.

"One of these dogs is of more essential use to the shepherd, than half-a-dozen boys would be; is more expeditious; and is at all times ready to obey commands. At a word from his keeper, he drives the sheep in order and regularity to and from their pasture, and will suffer no strangers from another flock to intrude upon his. If any of the sheep attempt to stray, he springs forward in an instant to stop their course. On the side of one of the Welsh mountains, I have seen a shepherd point out to his dog a straggling sheep, on a height more than a mile distant. He gave the wellknown signal. The dog went off at full speed, and soon returned with the animal to the flock.

"These dogs drive the sheep entirely by their voice, never lacerating them with their teeth; nor ever employing force, but for the preservation of peace and good order. When awake, they are at all times alive to their master's directions; and, in repose, they lie down by his wallet, and preserve it from plunder. If the shepherd be about to absent himself from the flock, he depends on his dog to keep the animals together; and if afterwards he is heard to give the command, this 


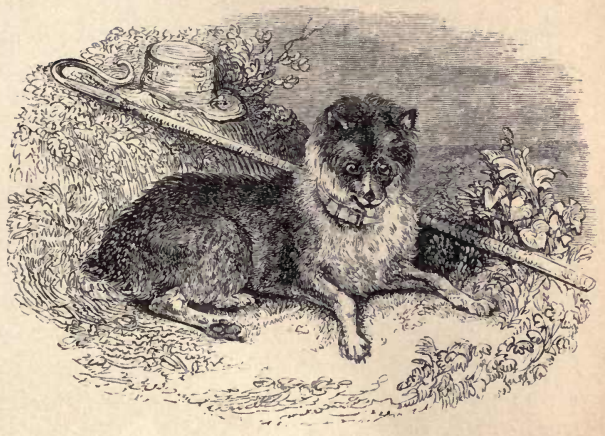

THE SHEPHERD'S DOG. 


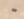

$=$ 
faithful servant conducts them to him with promptitude, however great the distance. In countries infested by wolves, he protects them from danger. His voice generally alarms and drives off the enemy, and collects the flock into a body, much better than the voice of the shepherd."

An affecting instance of the fidelity of the shepherd's dog is thus mentioned by the Rev. Thomas Young :- "I rest upon the authority of a friend, who told it to me as a fact which he had reason to credit. It occurred some years ago, in that part of Scotland which borders upon England. A shepherd had driven part of his flock to a neighbouring fair, leaving his dog to watch the remainder during that day and the next night, expecting to revisit them the next morning. Unfortunately, however, when at the fair, the shepherd forgot both his dog and his sheep, and did not return home till the morning of the third day. His first inquiry was, whether the dog had been seen. The answer was, 'No.' 'Then he must be dead,' replied the shepherd, with a tone and gesture of anguish, ' for I know he was too faithful to desert his charge.' He instantly repaired to the heath. The dog had just sufficient strength remaining to crawl to his master's feet, and express his joy at his return, and almost immediately expired." 
Hogg, the Ettrick Shepherd, has given some fearful tales of storms in the Highlands of Scotland. After referring to one of them, he says :- "When we came to the ground where the sheep should have been, there was not one of them above the snow. Here and there, at a great distance from each other, we could perceive the heads or horns of stragglers appearing, and these were easily got out; but when we had collected these few, we coutd find no more. They had been lying all abroad in a scattered state when the storm came on, and were covered over just as they had been lying. It was on a kind of sloping ground, that lay half beneath the wind, and the snow was uniformly from six to eight feet deep. Under this the animals were lying scattered over at least one hundred acres of heathery ground. It was a very ill-looking concern. We went about boring with our long poles, and often did not find one sheep in a quarter of an hour. But at length a white shaggy colly, named Sparkie, that belonged to the cowherd boy, seemed to have comprehended something of our perplexity, for we observed him plying and scraping in the snow with great violence, and always looking over his shoulder to us. On going to the spot, we found that he had marked straight above a sheep. From that he flew to another, and so on to another, as fast as we 
could dig them out, and ten times faster, for he sometimes had twenty or thirty holes marked beforehand.

"We got out three hundred of that division before night, and about half as many on the other parts of the farm, in addition to those we had rescued the day before; and the greatest part of these would have been lost had it not been for the voluntary exertions of Sparkie. Before the snow went away (which lay only eight days) we had got out every sheep on the farm, either dead or alive, except four; and that these were not found was not Sparkie's fault, for, though they were buried below a mountain of snow at least fifty feet deep, he had again and again marked on the top of it above them. The sheep were all living when we found them ; but those that were buried in the snow to a certain depth, being, I suppose, in a warm, half-suffocated state, though on being taken out they bounded away like roes, were instantly after paralyzed by the sudden change of atmosphere, and fell down, deprived of all power in their limbs. We did not, however, lose above sixty in all; but I am certain Sparkie saved us at least two hundred."

A shepherd's dog may render, however, a greater service. Among the Grampian mountains, there are glens chiefly inhabited by shepherds; and the pastures over 
which their flocks range, extend in every direction for many miles. It is the daily business of the shepherd to visit successively the different extremities of his pastures, and to turn back any of the flock that may be straying to those of his neighbours. It is a common practice with the Highlanders to accustom even their very young children to the rigours of the climate; and, on one occasion, a shepherd took with him an infant of about three years old. To have a more extensive view, he ascended a summit at some distance, and as this was too fatiguing for the child, he left him at the foot of the mountain, charging him not to stir till his return.

But scarcely had he reached the top, when one of the mists suddenly came on, which frequently fall so rapidly on these mountains as in a few minutes almost to change day into night. He instantly hastened back to find his child, but owing to the darkness and his own agitation, he missed his way, searched in vain among the morasses and cataracts of the mountains, and was, at last, overtaken by night. At length, as he wandered on, he came to the verge of the mist, and found by the moonlight, that he was within a short distance of his cottage. Further pursuit now appeared fruitless and dangerous, and he returned home, having 
lost not only his child but his dog, who had faithfully attended him for years.

At the break of day, the shepherd, accompanied by several of his neighbours, went forth in quest of the child, but without success. On returning to the cottage, at the approach of night, he found that his dog had been home, and had instantly left it on receiving a piece of cake, and so it was for several following days. He therefore determined to remain at home one day; and on the dog departing, as usual, with his cake, he followed him to ascertain the cause of so strange a procedure. The dog now led the way to a cataract, the banks of which, almost joined at the top, yet separated by an abyss of immense depth, presented a spectacle at once astonishing and appalling; and down one of these rugged and almost perpendicular descents he proceeded, and at last entered a cave, the mouth of which was almost on a level with the torrent. It was with difficulty that the shepherd followed; but on entering, he beheld, with feelings that cannot be described, his child, eating the cake the faithful dog had just brought.

It afterwards appeared, that the child had wandered from the spot where he was left, to the brink of the precipice, and then either fallen or scrambled down till he reached the cave; which he had not quitted from 
fear of the torrent. Hither he had been traced by the dog, who had never quitted him either night or day, except when it was necessary to go home for food, and he was then always seen running at full speed to and from the cottage.

To these stories we may now add another striking tale. A young shepherd having resolved to steal some sheep, selected the number one moonlight night, and set off with them towards Edinburgh; but before he had got them quite off the farm, his conscience smote him, or a dread of that which soon followed, and he quitted the sheep, letting them go again to the hill. He called his dog from them, and mounting his pony, rode away. At that time his dog was capering and playing around him, as if glad of having got free of a troublesome business; and he noticed him no more, till, after having rode about three miles, he thought again and again that he heard something coming up behind him. Halting, at length, to ascertain what it was, in a few minutes his dog came up with the stolen drove, driving them at a furious rate to keep pace with his master. The sheep were all smoking, and hanging out their tongues, and their driver was fully as warm as they. The young man was now exceedingly troubled; for the sheep having been brought so far from home, he dreaded there would 
be a pursuit, and he could not get them home again before day. Resolving, at all events, to keep his hands clear of them, he corrected his dog in great wrath, left the sheep once more, and taking his dog with him, rode off a second time.

He had not ridden above a mile, when he perceived that his dog had again given him the slip; and suspecting for what purpose, he was terribly alarmed as well as chagrined : for the daylight approached, and he durst not make a noise calling on his dog, for fear of alarming the neighbourhood, in a place where both he and his dog were known. He resolved therefore to abandon the animal to himself, and take a road across the country which he was sure his dog did not know, and could not follow. He took that road; but being on horseback, he could not get across the inclosed fields. He at length came to a gate, which he closed behind him, and went about half a mile farther, by a zig-zag course to a farm-house, where both his sister and another person with whom he was intimate lived; and at that place he remained until after breakfast-time.

The people of this house were all examined on the trial, and no one had either seen sheep, or heard them mentioned, save one man, who came up to the young man as he was standing at the stable-door, and told 
him that his dog had the sheep safe enough down at the Crooked Yett, and he needed not hurry himself. He answered, that the sheep were not his - they were young Mr. Thomson's, who had left them to his charge; and he was in search of a man to drive them, which made him come off his road. After this discovery, it was impossible for the poor fellow to get quit of them; so he went down and took possession of the stolen property once more, carried them on, and disposed of them ; and finally, the transaction cost him his life. What an illustration is thus afforded of the scriptural charge, "Be sure your sin will find you out!" The transgressor may be detected, as in this instance, by unlikely means. He who would be safe, and peaceful, and happy, must walk in the way of God's commandments.

\section{THE BLOOD-HOUND.}

This animal is larger than the common hound, and is generally of a deep tan or reddish colour, with a black spot over each eye. It is indebted for its name to the power it has of tracing wounded animals by their blood. In the early part of the sixteenth century, the 


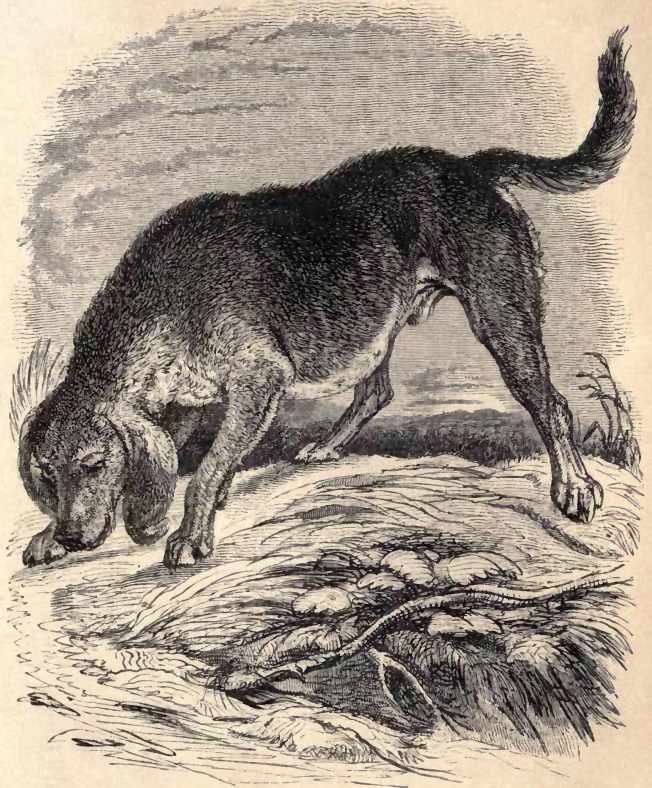

THE BLOOD HOUND. 
Spaniards employed these dogs in America, cruelly to hunt the defenceless Indians, that they might compel them to point out the gold mines.

One instance of the power of this hound may here be given. About forty years ago, a person getting over a stile into a field in the New Forest, remarked that there was blood on it. It almost immediately occurred to him that some deer had been slaughtered, and several sheep stolen in the neighbourhood; and that this might possibly be the blood of one of them killed the night before. The man went, in consequence, to the nearest lodge to give information; but the keeper being absent, he was compelled to go to another, which was at a considerable distance, and the under-keeper went with him from thence, accompanied by a blood-hound. The dog, being brought to the spot, was laid on the scent; and after following for about a mile the track which the depredator had taken, he came at last to a heap of furze faggots belonging to the family of a cottager. The woman of the house attempted to drive the dog away, but was prevented; and on the faggots being removed, a hole was discovered in the ground, which contained the body of a sheep recently killed, and also a considerable quantity of salted meat. This discovery is rendered the more remarkable by the $\operatorname{dog}$ not being 
brought to the scent until more than sixteen hours after the man had carried away the sheep.

\section{THE POINTER.}

This dog, with its stout limbs, blunt muzzle, stunted tail, and smooth hair, is the sportsman's companion. It is taught to discover game, and it practises what it has learned with great attention and steadiness. Its smell being very acute, it gently approaches the spot where the game lies, at length it stops, and fixes its eyes steadily upon it, with one foot commonly raised a little from the ground, and the tail extended in a straight line. When the birds run, the dog observes their motions, steals cautiously after them, preserving the same attitude, and when they stop, it is again steady.

Great sagacity has often been displayed by these animals. Thus a sportsman, on returning home, was accustomed to discharge his piece at magpies and crows, when the dog always kept behind at a little distance, that he might not frighten the birds. On one occasion a magpie, perched on the top of a large oak, escaped the sportsman's notice; but the dog was far more attentive. 
Peeping up to the tree, and descrying the party-coloured bird, he ran to his master, who was some yards off, took hold of his coat, and gave it a smart pull with his teeth. The sportsman, in surprise, turned back to see what was the matter, when the dog immediately trotted to the tree, and showed him the bird.

The following extraordinary story was related to $\mathrm{Mr}$. Jesse, by Lord Stowell. Mr. Edward Cook, after living for some time with his brother at Togsten, in Northumberland, went to America, and took with him a pointer dog, which he lost soon afterwards while shooting in the woods near Baltimore. Some time elapsed, and Mr. and Mrs. Cook, the relatives of the gentleman referred to, continuing to reside at Togsten, were alarmed at hearing a dog in the night. On admitting it into the house, they found it was the one taken to America. The sagacious animal lived with them till the return of his master from the western world, when the recognition was mutual. It was never found by what ressel the dog had left America, or in what part of England it was landed.

Very remarkable cases have occurred of the strong attachment of some animals to very different creatures, among which is that mentioned by Colonel Montague, as having subsisted between a China goose and a pointer 
who had killed the male. The dog was most severely punished for the misdemeanour, and had the dead bird tied to his neck. The solitary goose became extremely grieved for the loss of her partner, and only companion; and, probably having been attracted to the dog's kennel by the sight of her dead mate, she seemed determined to persecute the dog by her constant attendance and continual vociferation; but, after a little time, a strict friendship took place between these incongruous animals. They fed out of the same trough, lived under the same roof, and in the same straw bed kept each other warm; and when the dog was taken to the field, the lamentations of the goose were incessant.

\section{THE SPANIEL.}

This animal surpasses others of the canine species in its affection, gratitude, and patience, and is therefore a favoured inmate of many dwellings. Scarcely any thing is now heard of hawking; but when it was a fashionable diversion in the country, spaniels were used to spring the game. They are now sometimes employed in shooting water-fowl. 
In the summer of 1838 , a person named Alloway applied to the Lord Mayor (Cowan), at the Mansion House, under the following circumstances. $\mathrm{He}$ had lost a dog, which went by the name of Fan, from his shop some months before; and a few days prior to his application, seeing it pass by with a man who was a dog-fancier, he thought he had better seize the dog, which knew him perfectly, and insist on detaining it as his own property. The seizure was, however, at once resisted, and hence the matter was ultimately referred to the chief magistrate.

The Lord Mayor had, in consequence, to examine several witnesses, who were brought forward by both parties to prove the claim of each one, and the testimony on both sides was equally decided. In the course, however, of the long investigation, his lordship expressed an opinion, founded on several circumstances he observed, that the complainant Alloway was the rightful owner. The chief clerk too, having noticed his mentioning that he had received the dog from a gentleman named Newsom, and who had been a very kind master to it, proposed that he should be sent for; and a messenger was accordingly despatched for the previous owner of the animal.

Mr. Newsom, on arriving, looked at the dog, whose 
back was towards him, and told the Lord Mayor he had no doubt whatever upon the subject. He then described the marks on Fan's breast, feet, and face, which fully satisfied the chief magistrate of the correctness of his opinion. At this moment, the defendant was fondling Fan, who turned as before from one claimant to the other, as if anxious to conciliate both, when the Lord Mayor intimated that the dog would perhaps know Mr. Newsom; but that gentleman replied, that he thought it unlikely, as she was so young when he gave her to the complainant, adding, "Besides, her name is changed; I used to call her Primrose."

The instant the little creature heard the name, she started from the defendant, and springing towards $\mathrm{Mr}$. Newsom, flung her paws round his neck, licked his face, and was full of joy. No doubt in reference to the claim of Mr. Alloway could now exist, and to him the dog was at once given up.

The late Dr. Edward Walsh has given a very interesting account of his dog Quail, from which we extract the following particulars :- "When young, the first preparatory step was, to make her perfect in fetching and carrying whatever she was sent for, both in and out of the water, till both elements were alike to her; and this seemed the foundation of every thing else. She 
soon learned to distinguish what belonged to every person, and to every part of the person ; if I lost my glove, I showed my hand to Quail, and she set out on a quest, searched every place in and near the house, and almost always succeeded in finding it. This she soon improved into finding, of herself, whatever was dropped, and conyeying it to us. Many a pocket-handkerchief was saved in this way, which we never thought of sending Quail in search of.

"This faculty of recognising and carrying away things that had been touched by us, was used for a bad purpose, and severely compromised her character. There was an old woman who sold apples and oranges at the corner of the next street. We had a servant-boy who often set his eyes on them. One day he took up an orange, and asked the price of it; but thinking it too dear, the old woman snatched it out of his hand, and bade him go home. This was observed by Quail; and when he returned, she immediately ran back, snapped up the orange, and brought it to him in triumph.

"When this quality was discovered, it was soon put into requisition; and all the fruit-women of the town were laid under contribution. The appearance of Quail in the market put every one on the alert; and many a severe blow she received in doing as she was bid. She 
at last, however, became so sagacious, that she stole quietly behind the stall, watching her opportunity, and carried off the fruit without being perceived. When we found it out, we severely prohibited the practice.

"Her talent in carrying things in this way was sometimes useful to the servants. We had a very old woman who was fond of snuff, but not able to go for it herself. The boy was not always willing, and he taught Quail to be his substitute. When her box was empty, he put a halfpenny into it, and gave it to Quail, who forthwith carried it in her mouth to the snuff shop; and then, rising up to the counter with her fore-legs, she shook her head, and rattled the halfpenny in the box. This was soon understood by the shopman, who took the money and filled the box, which Quail brought safely back to our old woman.

"Within doors, her utility and sagacity were equally in requisition. We sat, in the winter time, in a large parlour, reading round the fire, with Quail between the legs of one of us, her head resting on our knees, and waiting for orders, either to ring the bell, or shut the door, as occasion might require. On this latter duty she was often sent, as it was usually left open by whoever came in, and the room was sometimes very cold.

"Her method was to lift up her right fore-paw (for 
she had actually a human preference for the use of the right hand), and push the door forward till the lock clicked.

"On one occasion, she could not move the door; and after sundry efforts she returned, whining in that peculiar way by which she expressed embarrassment. It appeared that the room was smoking, and the servant had opened the door to let the smoke out, and placed a smoothing iron against it to keep it so. Quail pondered for some time on the case, with her head on one side; when, as if the cause suddenly struck her, she ran at the smoothing iron, and having dragged it away, she pushed with both her feet against the door, shut it, and returned to us rejoicing. We often placed similar obstructions there, but Quail was never again embarrassed to find out the cause : she always, however, barked at it, and shook it after she had removed it, as if to express her displeasure for the trouble it gave her.

"Her power of distinguishing persons was also very great, and decided by means very different from the mere instinct of smell. A circumstance of this kind occurred, which highly gratified an eminent and very sensible artist. Of all the inmates of our family, Quail was most attached to my mother, who returned her good-will, and was very kind to her. She had sat for 
her picture, and afterwards gone on a visit to a friend for a short time; and Quail seemed very uneasy at her absence. The picture, which was a strong likeness, was sent home ; and before it was hung up, it stood on the sofa where my mother used to sit. I could not account one day for the boisterous joy of Quail in the dining-room; but, on looking in, I saw that she had recognised the picture, and was wagging her tail and frisking about, as she always did to express her joy, frequently looking up and licking the face-a mark of affection she tried to pay to those she was fond of. When the picture was hung up, she never failed to notice it when she entered the room, and lay before it on the carpet for some time, gazing at it intently ; and this practice she continued till my mother's return, and the original diverted her from the representation. The ingenious artist who drew it frequently declared that he considered this recognition the highest compliment that could be paid him.

"Quail was our constant companion wherever we went; and though alone, we never felt so when she was with us. She was a model of kindness and good temper; she was never known to quarrel with any animal, either of her own or our species, but seemed to love everything, quadruped or biped ; even our irri- 
table fox-cat, that could agree with no one else, never quarrelled with Quail, but often made a pillow of her side to lie on. She was never heard to growl, and seldom to bark, and that only to express her joy on recognising some person, either man, or dog, of her acquaintance; and she was so gentle, that she never gnawed or injured anything she took in her mouth to carry. She would fetch an egg from any distance without breaking it, and even meat and bread, which she would not presume to eat unless she had leave. Of living things she was particularly tender. Hunting ducks in ponds was an amusement of which we were too fond. When other dogs overtook the bird, they generally killed, and always gnawed it; but Quail took it by the feathers with great tenderness, and laid it at our feet, without doing it the smallest injury.

"Infirmity, at length, stole upon poor Quail, and she died at an early age. We all regretted the loss of an affectionate friend, whom we considered almost as one of ourselves, and who had endeared herself to us by so many fine and amiable qualities."

The fidelity and attachment of the spaniel have been celebrated in all ages. Of these qualities, the following is a gratifying instance : Old Daniel, the game-keeper of a gentleman, had reared a spaniel, which from its 
fondness, attended him both night and day. Wherever he appeared, Dash was never far distant; and in his nightly excursions to detect poachers, the dog was of great use.

During the last stage of a consumption which carried his master to the grave, Dash unwearily attended the foot of his bed; and when his friend expired, the dog would not quit the body, but lay on the bed by its side. With great difficulty the faithful animal was tempted to eat any food; and although after the funeral he was taken to the house of the gentleman by whom his master had been employed, he took every opportunity to steal back into the cottage where the game-keeper breathed his last, and where he would remain for hours. From thence, for fourteen days, he constantly visited the grave; and, though caressed with all the tenderness which so fond an attachment naturally excited, he died at the end of that time.

A similar fact may, perhaps, be recalled to the minds of some readers. Some years ago, a dog was constantly to be seen in St. Bride's Churchyard, Fleet Street, which for two years refused to leave the place where his master was buried. He did not appear miserable ; he evidently recollected their old companionship, and seemed to expect a renewal of their friendship. The 
inhabitants of the houses about the church daily fed the affectionate creature, and the sexton built him a kennel. But he would not quit the spot; - and there he died.

One instance of the effect produced by observing the attachment of a dog to its master, is worthy of record. At the battle of Castiglione, when the ranks of the Imperialists were broken, and the heat of pursuit was great, Bonaparte reached the spot where a multitude of French and Austrians had fallen, and amidst the pile of corpses he observed a little Barbet dog. The faithful animal stood with its fore-feet fixed on the breast of an Austrian officer, and its eyes were riveted on those of its dead master. Nothing occurred to divert his attention or alter his attitude. Bonaparte, struck with the sight, stopped his horse, called his attendants around him, and pointed it out to them.

"The dog," he said, "as if he had known my voice, removed his eyes from his master, and throwing them on me for a moment, resumed his former posture; but in that momentary look there was a mute eloquence beyond the power of language ; it was a reproach, with all the poignancy of bitterness." Bonaparte felt the appeal ; he considered the upbraidings of the animal a demand for mercy, and he gave orders for the carnage to be instantly stayed. 


\section{THE WATER DOG.}

The hair of this animal is long and curled, like the fleece of sheep, and the feet are more webbed than those of other dogs. Its qualities render it of great service to those persons in the north of England and Scotland who live principally by shooting water-fowl, in the retrieving of which it displays great docility and hardihood. Its accuracy in bringing back any articles which have been lost or purposely mislaid, is truly surprising. If, for instance, one be shown to a dog of this species, and then concealed, he may be sent from a distance a long time after, and he will search until he finds it, when he will carry it to his master.

"A friend of mine," says Mr. Bell, "possessed a bitch of nearly the same breed, which evinced a degree of intelligence scarcely less than human. One instance of her sagacity and faithfulness I cannot refuse myself the pleasure of recording. My friend was travelling on the continent, and his faithful dog was his companion. One day, before he left his lodgings in the morning, with the expectation of being absent until evening, he took out his purse in his room, for the purpose of ascertaining whether he had taken sufficient money for the day's 


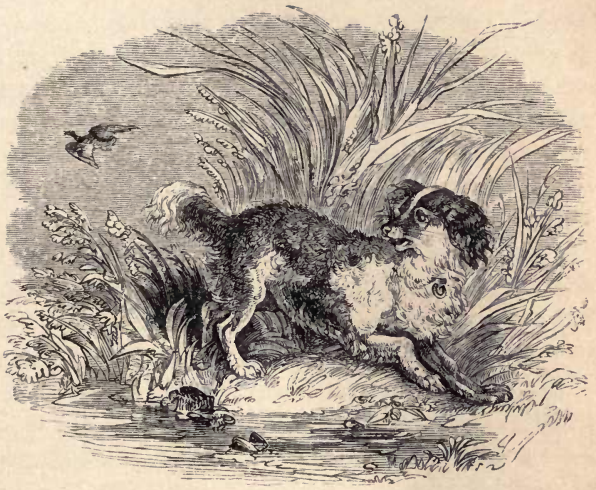

THE WATER DOG. 

occupation, and then went his way, leaving his dog behind. Having dined at a coffee-house, he took out his purse, and missing a louis-d'or, searched for it diligently, but to no purpose. Returning home late in the evening, his servant let him in with a face of much sorrow, and told him that the poor dog was very ill, as she had not eaten anything all the day; and what appeared very strange, she would not suffer him to take away the food from before her, but had been lying with her nose close to the vessel, without attempting to touch it. On my friend's entering the room, she instantly jumped upon him, then laid a louis-d'or at his feet, and immediately began to devour her food with great voracity. The truth was now apparent: my friend had dropped the money in the morning when leaving the room, and the faithful creature finding it, had held it in her mouth, until his return had enabled her to restore it into his own hands; even refusing to eat for a whole day, lest it should be out of her custody. I knew the dog well, and have witnessed many very curious tricks of hers, showing extraordinary docility." 


\section{THE TERRIER.}

With this dog every reader must be familiar. There are two distinct varieties of it: the one smooth and sleek, the other having rough hair, and not being so pleasing in form ; the former, too, is of a bright black colour, and the latter generally of a dirty white. The terrier is strong, active, and courageous ; it is the enemy of almost all kinds of vermin, and is therefore of great use in freeing places from rats, polecats, and other offensive animals. It is, also, a good house-dog.

Sir Walter Scott had among his dogs, with whose peculiarities he was greatly amused, a little shamefaced terrier, with large glassy eyes, and very sensitive to indignity and insult. "If ever I whipped him," said Sir Walter to a friend, "the little fellow would sneak and hide himself from the light of the day in a lumber garret, from whence there was no drawing him forth, except by the sound of the chopping-knife, as if chopping up his victuals, when he would steal forth with humiliated and downcast looks, but would slink away again if any one regarded him."

The following story exhibits many different qualities. 


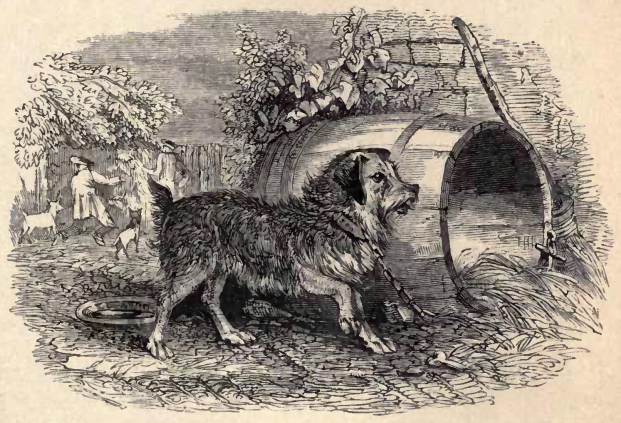

THE TERRIER. 

A lady, residing near Wrexham, in Shropshire, had a favourite terrier, who was much attached to her. As she was going, on one occasion, to a house of great formality at Chester, twelve miles from home, and intended to pay many visits, she left her dog behind in the care of the servants, who were strictly charged to take care of him. On the day after her arrival, however, she had scarcely taken her seat with a dinner-party of twenty, when it was found, from various growls, that a dog was under the table. To all such animals the lady of the house had a strong antipathy, and, as her husband kicked at the intruder, there were furious barkings and attempts to bite ; all became confusion, everybody rose, and the servants with brushes and sticks strove to drive out the dog. The lady referred to was, however, especially annoyed; for, as it leaped into her lap for shelter, it proved to be her own. It appeared that the terrier had gnawn asunder the rope which confined it, broke a pane of glass in the stable window, and made its escape. It had never been a mile on the Chester road, and yet it had traversed the whole dis. tance to the house which its mistress was visiting. The servants of it said, that the dog made its way into the passage, ran up into her bed-room, and not finding her there, had left it, and by some means or other gained 
access to the parlour, where it had coiled itself up under the table.

To Mr. Jesse, who authenticates the preceding story, we are also indebted for the one which follows. W. Y. Ottley, Esq., when a boy, passed a very pleasant day at the house of a man of taste and fortune in Yorkshire. As the party was seated in the arbour after dinner, he observed that a little cur dog was much caressed by the lady of the house, and remarked that it was no beauty, when he heard that it had other and better claims to regard. It had belonged to a poor cottager just by, who, during the preceding winter, was returning from the market-town some distance off, and perished in a snow-storm by which she was overtaken. So deep was the snow-drift, that her body was not discovered till three days afterwards, when the dog was found lying close to his mistress with her basket of eatables untouched. It was then remembered-unhappily too late - that the faithful animal had been in the village on the evening of the snow-storm, and, by whinings and pullings at their clothes, had in vain endeavoured to induce some of the poor woman's neighbours to afford her relief. 


\section{THE NEWFOUNDLAND DOG.}

This general favourite was brought from the island to which it owes its name. There it is employed as a beast of draught, and brings loads of wood and provision over a rough and difficult country. It probably surpasses, as a water-dog, every other kind. Landseer has a fine picture, which he describes as " a distinguished member of the Humane Society,"-it is a portrait, most admirably painted, of a Newfoundland dog, who has been successful in the saving of life.

One of these animals, which was kept at the ferryhouse at Worcester, was the means of rescuing, at different times, three persons from drowning. This faithful creature was exceedingly fond of the water, and seemed even to consider a disinclination for it by other dogs, an insult on the species. Thus, were one left by its master on the bank, and if it stood yelping at the bottom of the steps, unwilling to follow the boat across the river, he would go down to him, growl as if in mockery at his fears, take him by the back of his neck, and throw him into the stream.

A native of Germany, fond of travelling, was pursuing his course through Holland, accompanied by a large 
Newfoundland dog, when he fell from a high bank into a dyke or canal, from his foot slipping; and, as he was unable to swim, he soon became senseless. On recovering his recollection, he found himself in a cottage on the opposite side of the dyke from which he had fallen, surrounded by peasants who had been using the means so common in that country to restore animation. They told him that one of them, returning from labour, observed at a considerable distance a large dog in the water, swimming and dragging, and sometimes pushing something which he seemed to have great difficulty in supporting, but which he at length succeeded in getting into a small creek on the opposite side to that on which the men were.

When the animal had pulled what he had hitherto supported as far out of the water as he was able, the peasant discovered that it was the body of a man. The dog having shaken himself began industriously to lick the hands and face of his master, while the peasant hastened across ; and, having obtained assistance, the body was removed to a neighbouring house, where the means employed providentially proved effectual. Two very considerable bruises, with the marks of teeth, appeared, one on the shoulder, the other on the nape of the neck; whence it was presumed, that the faithful animal first 


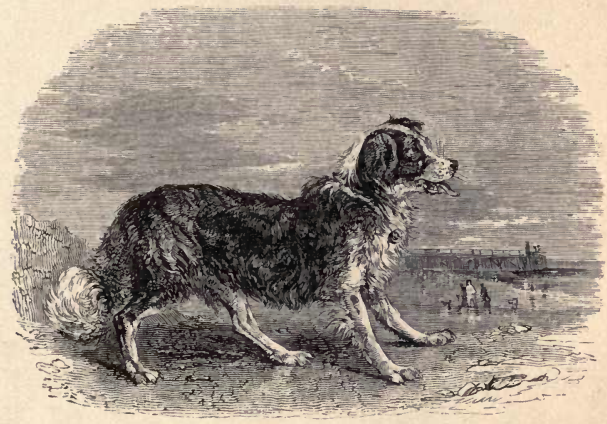

THE NEWFOUNDLAND DOG. 


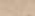

$+$ 
seized his master by the shoulder, and swam with him in this manner for some time; but that his sagacity prompted him to let go his hold, and shift his grasp to the neck, by which he was able to support the head out of the water. It was in the latter position that the peasant observed the dog making his way along the dyke, which it appeared he had done for nearly a quarter of a mile.

Here was an extráordinary display of sagacity, as well as faithfulness, and to this quality the master of the noble animal appears to have been indebted instrumentally for his deliverance from death. The feelings with which he regarded the companion of his journeys would doubtless be strengthened by his merciful escape. It is to be hoped, too, that he considered the claims of his unseen Preserver; while we may be reminded by the narrative, of our dependence on God, and reproved for our disregard of his favours. An interposition in our behalf by a fellow-creature, or even a sagacious animal, has often excited more gratitude to the instrument than all the gifts so richly bestowed on us from our birth have awakened to our heavenly Father.

The following is a remarkable deliverance in very different circumstances. Lord Forbes was asleep in his house at Castle Forbes, when he was awakened by a 
sense of suffocation, which deprived him of the power of stirring a limb, yet left him sensible that his house was on fire. At this moment, and while his apartment was in flames, his large dog jumped on the bed, seized him by the shirt, and dragged him to the stair-case, where the fresh air restored his powers of escape. "This is very different," as Sir Walter Scott remarks, "from most cases of the preservation of life by the canine race, when the animal generally jumps into the water, in which element he has force and skill. That of fire is as hostile to him as to mankind."

Some Newfoundland dogs display their power in a great variety of ways. According to Captain Brown, Mr. M·Intyre, patent mangle manufacturer, Regent Bridge, Edinburgh, has a dog whose sagacious qualifications are truly astonishing and almost incredible. As the animal continues daily to give the most striking proofs of his powers, he is well known in the neighbourhood, and any person may satisfy himself of the reality of those feats, many of which the writer has himself had the pleasure to witness.

Some gentlemen being in company one evening, one of them accidentally dropped a shilling on the floor, which, after the most careful search, could not be found. Mr. M. seeing his dog sitting in a corner, and looking as 
if quite unconscious of what was passing, said to him, "Dandie, find us the shilling, and you shall have a biscuit." The dog immediately jumped upon the table, and laid down the shilling, which he had previously picked up without having been perceived.

At another time, having been left in a room in the house of Mrs. Thomas, High-street, he remained long quiet; but, as no one opened the door, he became impatient, and rang the bell ; and when the servant opened the door, she was surprised to find the dog pulling the bell-rope. Since that period, which was the first time he was observed to do it, he pulls the bell whenever he is desired; and, what appears still more remarkable, if there is no bell-rope in the room, he will examine the table, and, if he finds a hand-bell, he takes it in his mouth and rings it.

A number of gentlemen, well acquainted with Dandie, are daily in the habit of giving him a penny, which he takes to a baker's shop and purchases bread for himself. One of these gentlemen, who lives in St. James's-square, when passing some time ago, was accosted by Dandie, in expectation of his usual prese_t. Mr. T. then said to him, "I have not a penny with me to-day, but I have one at home." Having returned to his house some time after, he heard a noise at the door, which was 
opened by the servant, when in sprang Dandie to receive his penny. In a frolic, Mr. T. gave him a bad one, which he, as usual, carried to the baker, but was refused his bread, as the money was bad. He immediately returned to Mr. T.'s, knocked at the door, and, when the servant opened it, laid the penny down at her feet, and walked off, seemingly with the greatest contempt.

Although Dandie, in general, makes an immediate purchase of bread with the money which he receives, yet the following circumstance clearly demonstrates that he possesses more prudent foresight than many who are reckoned rational beings.

One Sunday, when it was very unlikely that he could have received a present of money, Dandie was observed to bring home a loaf. Mr. M. being somewhat surprised at this, desired the servant to search the room, to see if any money could be found. While she was engaged in this task, the dog seemed quite unconcerned till she approached the bed, when he ran to her, and gently drew her back from it. Mr. M. then secured the dog, which kept struggling and growling, while the servant went under the bed, where she found sevenpence-halfpenny under a bit of cloth; but from that time he never could endure the girl, and was fre- 
quently observed to hide his money in a corner of a saw-pit, under the dust.

When Mr. M. has company, if he desire the dog to see any one of the gentlemen home, it will walk with him till he reach his abode, and then return to his master, how great soever the distance may be.

A gentleman living with Mr. M. going out to supper one evening, locked the garden gate behind him, and laid the key on the top of the wall, which is about seven feet high. When he returned, expecting to let himself in the same way, to his great surprise the key could not be found, and he was obliged to go round to the front door, which was a considerable distance about. The next morning strict search was made for the key, but still no trace of it could be discovered. At last, perceiving that the dog followed him wherever he went, he said to him, "Dandie, you have the key-go fetch it." Dandie immediately went into the garden, and scratched away the earth from the root of a cabbage, and produced the key, which he himself had undoubtedly hid in that place.

If his master place him on a chair, and request him to sing, he will instantly commence a howling, which he gives high or low, as signs are made to him with the finger. 
A few years ago, a mangle was sent by a cart from the warehouse, Regent Bridge, to Portobello, at which time the dog was not present. Afterwards, Mr. M. went to his own house, north back of the Canon-gate, and took Dandie with him, to have the mangle delivered. When he had proceeded a little way, the dog ran off, and he lost sight of him. He still walked forward; and in a little time he found the eart in which the mangle was, turned towards Edinburgh, with Dandie holding fast by the reins, and the carter in the greatest perplexity: he now stated that the dog had overtaken him, jumped on his cart, examined the mangle, and then had seized the reins of the horse, and turned him fairly round, and would not let go his hold, although he had beaten him with a stick. On Mr. M.'s arrival, however, the dog quietly allowed the carter to proceed to his place of destination.

In passing from the consideration of the dog to that of other animals, the reader will not regret the introduction of another fact, as stated by Mr. Jesse, and exhibiting very extraordinary sagacity. Mr. Henry Hawkes, a farmer, residing at Halling, in Kent, was late one evening at Maidstone market. On returning at night with his dog, who was usually at his heels, he again stopped at Aylesford, and, as is too frequently the case on such occasions, 
he drank immoderately, and left the place in a state of intoxication. Having passed the village of Newheed in safety, he took his way over Snodland Brook, which, in the best season of the year, is a very dangerous road for a drunken man. At this time, the whole face of the country was covered with a deep snow, and the frost was intense : he had, however, proceeded in safety till he came to the Willow Walk, within half a mile of the church, when, by a sudden stagger, he quitted the path, and passed over a ditch on his right hand. Not apprehending he was going astray, he took towards the river; but having a high bank to mount, and being nearly exhausted with wandering and the effect of the liquor, he was providentially prevented from rising the mound, or he certainly must have precipitated himself (as it was near high-water) into the Medway.

At this moment, completely overcome, he fell amongst the snow in one of the coldest nights ever known, turning upon his back. He was soon overpowered with either sleep or cold; when his faithful dependant, who had closely attended to every step, scratched away the snow so as to throw up a sort of protecting wall around his helpless master, then mounting upon the exposed body, rolled himself round, and lay upon his master's bosom, for which his shaggy coat proved a most sea- 
sonable covering and eventual protection during the dreadful severity of the night, the snow falling all the time. The following morning, a person who was out with his gun, in expectation of finding some wild-fowl, perceiving an appearance rather uncommon, ventured to approach the spot. On his coming up, the dog got off the body; and, after repeatedly shaking himself to get disentangled from the accumulated snow, encouraged the sportsman (a Mr. Finch) by actions of the most significant nature to come near the side of his master. On wiping away the icy incrustation from the face, the countenance was immediately recollected; but, the frame appearing lifeless, assistance was procured to convey it to the first house upon the skirts of the village, when, a pulsation being observed, every possible means was instantly adopted to promote recovery.

After a short time, the farmer was sufficiently restored to relate his own story, as already recited; and, in gratitude for his miraculous escape, ordered a silver collar to be made for his friendly protector, as a perpetual remembrance of the transaction. A gentleman of the faculty in the neighbourhood hearing of the circumstance, and finding it so well authenticated, immediately made him an offer of ten guineas for the dog, which the farmer refused, exultingly adding, "That, so long 
as he had a bone to his meat, or a crust to his bread, he would divide it with his faithful friend, who had preserved his life :" and this he did with the perfect conviction that the warmth of the $\mathrm{dog}$, in covering the most vital part of the body, had continued the circulation, and prevented the entire stagnation of the blood by the intense cold.

It is not stated that so remarkable a deliverance from death was followed by the abandonment of intemperance; yet such ought, assuredly, to have been one of its results. The man who yields himself to the dominion of this shameful and filthy vice, sinks far below the level of the beasts that perish. No effort- no sacrifice should therefore be refused for its prevention or correction. The health - the character - all the temporal and eternal interests of the deathless spirit, raise their voice against it. $\mathrm{Oh}$ that it were heard by all who are caught in the snare of intemperance, or in danger of becoming so ; while it ought ever to be remembered that the grace of God is the only effectual corrective of evil, and that he who would be temperate in all things, must be truly pious ! 


\section{THE GOAT.}

"The goat," says Goldsmith, "seems in every respect more fitted for a life of savage liberty than the sheep. It is naturally more lively, and more possessed with animal instinct. It easily attaches itself to man, and seems sensible of his caresses. It is also stronger and swifter, more courageous, and more playful, lively, capricious, and vagrant ; it is not easily confined to the flock, but chooses its own pastures, and loves to stray remote from the rest. It chiefly delights in climbing precipices; in going to the very edge of danger; it is often seen suspended on an eminence, hanging over the sea, upon a very little base, and even sleeps there in security."

In Switzerland, at this day, most of the peasants in a parish possess a few goats, which go out together in the morning in a flock, to the number of perhaps two hundred, and return in the evening. The eyes of the people have long been familiar with these animals and their regular movements, but to those of strangers the 


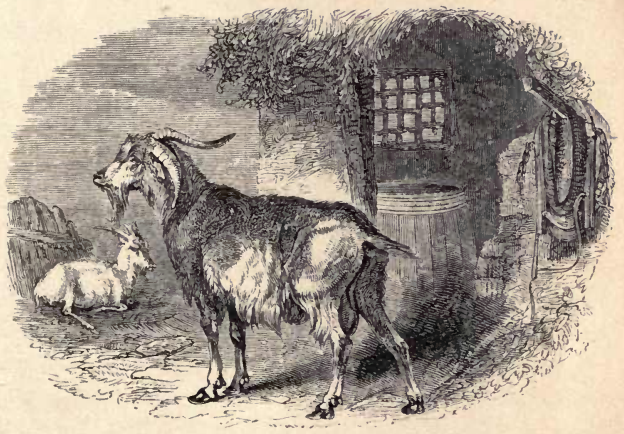

THE GOAT. 

sight is remarkable and interesting. Inanimate nature has often its peculiar charms, but these are increased by evidences of life ; and the romantic and sublime scenes of Switzerland may be gazed on with greater pleasure, when troops of goats are passing towards the mountains, where they love to graze, or returning with the closing day from their usual pasturage.

In another part of Europe they render a singular service. In the spring of the year the sheep are driven in troops of from 10,000 to 40,000 from the plains of Arles, and the Delta of the Rhone, towards the Alps, which divide Provence and Dauphiné from Italy. To every thousand of these sheep there are three shepherds, each of whom has his $\operatorname{dog}:$ a troop of asses carries the provisions and baggage in the centre of the flock. One shepherd is chosen by the rest to direct the march, and to bear a common purse, from which its expenses are to be defrayed. He travels in the centre, issues the daily allowance of food, decides on the complaints of any farmers on the road, if damage has been accidentally or wilfully done, and punishes the shepherds if convicted of offence.

The leaders of the sheep are goats, wearing bells round their necks, and trained for their service. The intelligence they display, and the discipline in which 
they are kept, are alike great. At the direction of the shepherd, they halt or proceed; they advance to the centre at the close of each day's march, and wait there in the morning for the proper order, when they repair to their station at the head of the troop with the greatest regularity. When they come to a stream, they halt until the word of command; and as soon as it is given, they plunge into the water, and are followed by the rest of the flock. The journey usually lasts from twenty to thirty days. On their arrival at the mountains, each shepherd has his appointed boundary marked out, and the proprietors of the land are paid a small sum for the sheep's pasture during the summer. The shepherds live almost entirely on bread and goat's milk.

The following is an instance of strong attachment as displayed by one of these animals. A gentleman, who had been actively employed in the rebellion of 1745 , escaped to the Western Highlands, where a female relative afforded him an asylum after the battle of Preston. That he might elude discovery, a cavern, in a sequestered situation, not far from the house, was considered the best place he could have. A faithful servant accordingly conducted him thither, with an ample store of food.

The approach to this lonely abode was a small 
aperture, through which the fugitive crept, and dragged his provisions along with him. A little way from the mouth it became much higher, and, indeed, was rather lofty in the roof; but, on advancing, an obstacle impeded his progress. He drew his dirk, but was unwilling to strike, lest he might take away the life of a fellow-creature in seclusion; and, stooping down, he discovered it was a goat with her kid lying on the ground. He soon found that the animal was in great pain, and, feeling her body and limbs, ascertained that one of her legs had been fractured. He bound it up with his garter, and offered her some of his bread; but she refused to eat, and stretched out her tongue, showing that her mouth was parched with thirst. He then gave her water, which she drank eagerly ; and after her thirst was allayed, she partook of the bread.

At the dead hour of night he ventured from the cave, and, after listening attentively, he pulled a quantity of grass and the tender branches of trees, and carried them to the sufferer, by whom they were received with expressions of gratitude. The only thing which the fugitive had to employ him in his drear abode, was administering comfort to the goat, and even for the presence of this living creature he felt thankful. The goat quickly recovered, and felt to him a strong attachment. 
It happened that the servant who was intrusted with the secret of his retreat fell sick, when it became necessary to send another with provisions. On this occasion the goat, happening to be lying near the mouth of the cavern, opposed his entrance with all her might, butting him furiously. The fugitive, hearing the disturbance, went forward, and receiving the watch-word from his new attendant, interposed, when the faithful animal permitted him to pass. So resolute, however, was the goat, that her benefactor was convinced she would have died in his defence. 


\section{THE BAT.}

THE common bat is about the size of a small mouse, and measures nearly nine inches from the tip of one wing to that of the other, when they are fully open. The ears are short, and have a small inner valve. The eyes are very small. The fur is of a reddish mouse colour. The whole structure of the bat is admirably adapted for flight. The fore part of its body, though consisting essentially of the same parts as that of man, has its different bones so modified as to afford the most complete support to an extensive expansion of the skin, which thus forms a perfect pair of wings. The difference principally consists in the extraordinary lengthening of the fingers, on which the skin is stretched like the silk on the rods of an umbrella. Of these fingers, the thumb is the only one that is left free ; it is of moderate length, and furnished with a hooked nail. The hinder toes are short, of nearly equal length, and are chiefly used as suspending organs, the bats hanging by 
them from the trees or walls on which they rest, with the head downwards.

The flying membrane is also frequently used as a cloak or mantle, in which these little creatures do not only shroud themselves, but the females hold and shelter their young. It also answers other interesting purposes, and among them one which deserves particular attention. It was found by Spallanzani, by a course of cruel experiments which cannot be mentioned without censure, that bats, when deprived of sight, and so far as possible of hearing and smelling, still flew about safely and certainly, avoiding every obstacle, passing through passages only just large enough to admit them, and moving about places formerly unknown; and that when he stretched threads in various directions across the apartment, there was also the same result. Cuvier considered these experiments, therefore, as affording a proof that the sense of touch was diffused over the whole surface of the flying membrane.

This provision for the comfort of the bat has many analogies in the circumstances of other animals. Those which move about much in the dark, have commonly hairs or whiskers projecting from the upper lip, which guide them in their passage through narrow places and holes. They serve as feelers, and are exactly of such a 


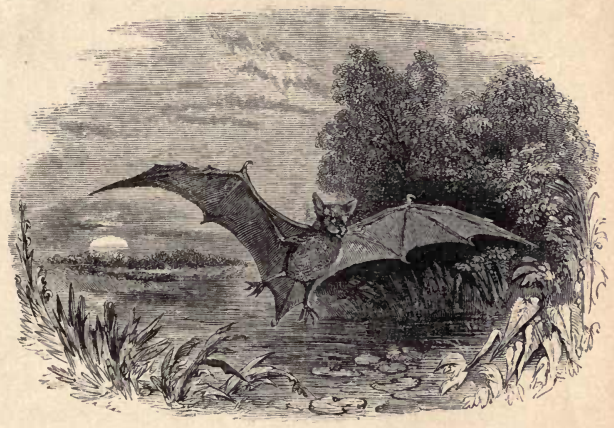

THE BAT. 
length that the body of the creature will pass through any opening which these hairs do not touch on either side. They are very sensitive; and, if ever so lightly touched, the animal is instantly aware of it, even while asleep. Horses have strong hairs both on the upper and lower lips, but they are probably designed to keep flies and insects from annoying them by getting into their nostrils while grazing. Sufficiently close for this purpose, and moving as they do, while the horse is feeding, they serve to brush away anything offensive.

To return now to the bat : the extremities afford the means of walking on the ground, and of climbing easily up perpendicular places, if there are sufficient inequalities on the surface to allow of a firm hold by the little hooked nail of the thumb. In walking, the wings are closed, the long fingers being folded against the arm, and the animal rests upon the wrist. The foot of one side is then stretched forward, and the thumb-nail is hooked into the ground ; the body is next raised by means of the hinder foot, which has been placed partly under the body, and thus thrown onward; the other side is next moved in the same manner, and by a succession of these plunges the animal runs,-oddly, compared with other animals, but in a manner sufficient for its wants.

During the day, bats sleep in the most retired places, 
as, in the darkest retreats of forests, in the hollows of trees, or suspended from the bark; others in the roofs of churches, the most inaccessible parts of ruins, or in various places equally unfrequented. As soon as twilight appears, they come abroad, pursuing those insects which, like themselves, aroid the glare of day, moving variously and rapidly, sometimes flying swiftly over the surface of the water, then rising to a considerable height in the air, and turning suddenly from side to side, as their prey make efforts to escape.

The long-eared bat is one of the most common of these creatures in our country. The extraordinary size of the parts from which it derives its name, their beautiful transparency, and the elegant curves into which they are thrown at the will of the animal, render it by far the most pleasing. It is also more readily tamed than any other, and may soon be brought to considerable familiarity with those who feed and caress it. It is very playful, running over and against others, pretending to bite, but never harming its companions of the same species ; and its gambols are not the less amusing from their awkwardness.

These bats may be readily brought to eat from the hand; and one which a gentleman recently had, when at liberty in the parlour, would fly to any of the young 
people who held up a fly towards it, and, even pitching on the hand, it would take the insect without hesitation. If the fly were held between the lips, the bat would then settle on the cheek, and take it very gently from the mouth. Even when a humming noise was made, in imitation of an insect, the bat would search about the lips for the promised dainty.

Another kind of bat, a Barbastelle, was taken during a very hard frost, in the latter end of December, from a large chalk cavern, to which several species are found to retreat, with some others of different kinds. When brought into a warm room, they soon began to exhibit signs of vivacity; and the Barbastelle, with the rest, fed readily on small bits of meat, and drank water. $\mathrm{He}$ was a timid creature, and did not show the slightest disposition to become acquainted with his host; but he would take his food with his companions, and used to rest with them in a cluster, at the top of the box in which they were placed.

The Barbastelle became torpid more readily and completely than any of the others ; but, when awake, he was very restless, and was constantly biting violently against the wires of his box. When suffered to fly about the room, he flew very low, and less actively than the rest; and was fond of lying before the fire on the 
hearth-rug, where he appeared greatly to enjoy the warmth. The long-eared bats showed great attachment to each other, and became very familiar with their host; but the Barbastelle remained sullen and apart. At length, it appeared that he was persecuted by his companions, one of whom was seen to give him a severe bite on the back of the neck. This occasioned his immediate removal to another box; but it probably hastened his death, which happened about a week afterwards.

Bats have been long regarded with prejudice. The poet and the painter have alike derived from them images of terror. And yet, whatever feelings they may awaken by predatory habits in other lands, it should be remembered that in our own climate they are at once innocent and amusing. Their time of appearance and activity fully comport with the season that invites to tranquillity; and amid the calmness of a summer's evening they are often regarded with considerable interest. As, too, all the European species of bats feed wholly on insects, which they catch during their flight, they are doubtless of great use to mankind. They devour numbers of night-flying moths, the caterpillars of which would injure our fields, orchards, and gardens. 


\section{THE HEDGEHOG.}

THIs animal commonly resides in hedgerows and thickets. It lies concealed in its hole during the day, and at night wanders abroad in search of food, which consists of fruits, succulent roots, frogs, and snails. The manner in which hedgehogs devour the roots of plantain is very curious : with the upper jaw, which is much longer than the lower, they bore under the plant, and so eat the root upwards, leaving the tuft of leaves untouched. "In this respect they are serviceable," says Gilbert White, "as they destroy a very troublesome weed; but they deface the walks in some measure by digging little round holes."

The mode in which the hedgehog defends itself from the assaults of other animals is very uncommon. Possessed of but little strength or agility, it neither attempts to fly nor to attack its enemies, but erects its bristles and rolls itself up like a ball; exposing no part of its body that is not covered with these sharp weapons. It will not unfold itself unless thrown into 
water; and the more it is harassed or frightened, the closer it shuts itself up. While in this state, most dogs stand off and bark, not daring to seize it; and if they once attempt to make it a prey, their mouths are so pricked with its bristles, that it is with difficulty they can be made to repeat the attack. It has no other means of protection, and consequently is easily taken.

Mrs. Charlotte Smith, when she condemned all wanton assaults on this animal, thus addressed a hedgehog, observed in a frequented path ; but, as we have seen, its food is more various than she has stated it to be.

Wherefore should man, or thonghtless boy,

Thy quiet, harmless life destroy,

Innoxious urchin?-For thy food

Is but the beetle and the fly,

And all thy harmless luxury

The swarming insects of the wood.

Should man, to whom his God has given

Reason, the brightest ray of heaven,

Delight to hurt, in senseless mirth,

Inferior animals? - and dare

To use his power in waging war

Against his brethren of the earth ?

Poor creature! To the woods resort,

Lest, lingering here, inhuman sport

Should render vain thy thorny case;

And whelming water, deep and cold,

Make thee thy spiny ball unfold,

And show thy simple negro face? 
"In the month of June, 1782," says a correspondent in the Gentleman's Magazine, " a full-grown hedgehog was put into a small yard, in which was a border of shrubs and annuals. In the course of a few days he formed, beneath a small holly-tree, a hole in the earth, sufficiently large to receive his body. After a while, a small shed was built for him in the corner of the yard, and filled with straw ; but the animal would not quit its former situation until it was covered with a stone. $\mathrm{He}$ then took possession of the shed, and every morning carried leaves from a distant part of the border, to stop its mouth. His principal food was raw meat and mice. Of the latter he would eat six at a time, but never more; and, although these were thrown to him dead, he bit them all in the neck before he began to eat any. He would also eat snails with their shells, but would leave anything for milk, which he lapped exceedingly slow. To this, even if set six or eight yards distant from his shed, he would almost always come out half an hour before his usual time. If the person who usually fed him neglected to do so, he would follow him along the yard; and, if the door was open, he would go into the house. If meat was put near the mouth of his shed in the day-time, he would sometimes pull it in, and eat it. As the weather became colder, he carried more leaves 
into his shed; and sometimes he would not come out for two or three days successively. About the end of November he died; from want of food, as was supposed, but most probably from the severity of the weather."

The hedgehog is fond of insects, and is sometimes introduced into houses, for the sake of expelling cockroaches. The Calmuc Tartars, it is said, keep it sometimes instead of a cat, and in some respects it answers the same purpose. The landlord of the Angel Inn at Felton, Northumberland, kept a hedgehog some years ago, which answered to the name of Tom, and did the service of a turnspit dog. It was very docile, and ran familiarly about the house. Another is described as unfolding, and lying on the knees of its owner before the fire; it suffers him also to rub the naked parts of its face, from which it appears to derive great pleasure. 


\section{THE POLECAT.}

THe fur of the common polecat is of two sorts : the one long and shining, of a brown colour; the other, silky, short, and yellowish, or fulvous white. From the habits of this species, it is extremely destructive, as every animal it can conquer falls a victim to its appetite. It is strong and active ; and by bringing all the feet together, and drawing the back into an arch, it springs with great force on its intended prey, which it generally kills expeditiously, and with a single bite on the head.

On a female polecat being pursued to its nest, which is usually in woods or coppices, and near to farms, there were found five young ones, comfortably embedded in dry withered grass; and in a side hole forty large frogs and two toads were picked out. They were all alive, but merely so ; for the mother had contrived that they should all be paralysed. They could only sprawl a little, but not move away; and, on the whole number being examined, they were found to be bitten through 
the brain. This fondness of the polecat for frogs has often been observed, and it accords with the habits of some of its congeners, or kindred animals.

According to Bewick, one of these animals was traced in the snow from the side of a rivulet to its hole, at some distance from it, during a severe storm. As it was observed to have made frequent trips, and as other marks were to be seen in the snow, which could not easily be accounted for, it was thought a matter worthy of greater attention. Its hole was therefore examined, the polecat taken, and eleven fine eels were discovered to be the fruit of its nightly exertions. The marks on the snow were found to have been made by the motions of the eels while in the creature's mouth. 


\section{THE WEAZEL.}

THe usual colour of this active little creature is pale reddish brown on the back, sides, and legs ; the throat and belly are white. It has long whiskers, like a cat, and its teeth are very sharp. It is well known to all engaged in agriculture, in almost every part of Great Britain, from its great antipathy to rats and mice. In barns and granaries it is very useful ; and it can pursue its prey through a wheat-rick, to which its power of scent, as well as its great agility, fully adapt it. With its head raised a little above the ground, it follows the track of a rat or a mouse after it has disappeared. Three bushels of mice are said to have been killed out of one rick; and the value of the weazel in preventing and checking the depredations of creatures so numerous and injurious to the farmer, has often been proved.

This animal does not easily give up the pursuit of its prey. A man of much observation, who had set a common trap, finding that a mole was taken, took the trap from the ground, and allowed the mole to be suspended 
in it. While working in the neighbourhood, he chanced to look at the trap, and observed a weazel actively engaged in trying to detach the mole from the wires that held it. The weazel ran up the stick which formed the spring of the trap, and descended on the captive, which he seized; he then tried by various movements to disengage the mole from the trap, but was not able to effect his purpose. Tired by his fruitless efforts, he relinquished his hold, and dropped to the ground; there he rested for some time, but afterwards he climbed the stick again, and renewed his exertions with increased ardour. The workman at length took the mole from the trap, and threw it down as a reward for his perseverance; but on seeing him the weazel made his escape, and did not return while he remained.

The weazel is sometimes the prey of hawks, but the ingenuity of an inferior enemy may outmatch violence and rapine, though accompanied by superior strength. As a gentleman was riding over his grounds in Dorsetshire, he saw, at a short distance from him, a kite pounce on some object on the ground, and rise with it in his talons. In a few moments, however, the kite appeared to be very uneasy, rising rapidly in the air, or as quickly falling, and wheeling irregularly round, while it was evidently endeavouring to force some obnoxious thing 
from it with its feet. After a short but sharp contest, the kite fell suddenly to the earth, when the gentleman, who had intently observed what was occurring, rode up to the spot. At this moment a weazel, apparently unhurt, ran away from the kite, leaving the bird dead.

The following is a fact of a different kind :- "One fine summer evening," says Captain Brown, "my father was returning from Gilmerton, near Edinburgh, by the Dalkeith road. He observed on the high ground, at a considerable distance betwixt him and Craigmillar Castle, a man, who was leaping about, performing a number of antic gestures, more like those of a madman than of a sane person. After contemplating this apparently absurd conduct, my father began to think it might be some unfortunate maniac, and climbing over the wall made directly towards him; when he got pretty near, he perceived that the man had been attacked, and was defending himself against the assaults of a number of small animals, which he at first took for rats, but which, in fact, turned out, on getting closer, to be a colony of from fifteen to twenty weazels, and which the man was tearing from him, and endeavouring to keep from his throat.

"My father joined in the combat, and, having a stick, contrived to hit several of them, and laid them 
lifeless. Seeing this, the animals became intimidated, and speedily fled towards a rock hard by, and disappeared in its fissures. The gentleman was nearly overcome with fatigue and exhaustion, having been engaged in his struggle with the weazels, as far as he could guess, upwards of twenty minutes; and, but for the timely assistance of my father, he said he must have inevitably fallen a victim to their fury, as he found himself quickly losing strength, from the violence of his exertion. His chief attention was turned to keeping them from his throat, to which they seemed instinctively to direct their course. He was a powerful man; otherwise he must have sunk under their ferocity. He had squeezed two to death, while tearing them from him. His hands were much bitten, and were streaming with blood from the wounds.

"The account he gave of the commencement of the affray was, that he was walking slowly through the park, when he happened to see a weazel; he ran at it, and made several unsuccessful attempts to strike it with a small rattan he had in his hand; on coming near the rock above mentioned, he got betwixt it and the animal, and thus cut off his retreat; the weazel squeaked aloud, when an instantaneous sortie was made by the whole colony, and the attack commenced." 
Although Buffon was of opinion that the weazel, so formidable in this instance, is an animal incapable of domestication, we have the following interesting account of one in a letter of Mademoiselle de Laistre :- "If I pour some milk into my hand, it will drink a good deal ; but, if I do not pay it this compliment, it will scarcely take a drop. When it is satisfied, it generally goes to sleep. My chamber is the place of its residence; and I have found a method of dispelling its strong odours by perfumes. During the day it sleeps inside a quilt, entering by a place that is unsewed in its edge, which it accidentally discovered. At night, I keep it in a wire cage, which it always enters with much reluctance, but leaves with joy. If the servant sets it at liberty before I am up in the morning, after a thousand gambols, it comes into my bed, and reposes in my hand, or on my bosom. If I am up before it is let out, it will fly to me in rapture, and spend half an hour in caressing me, playing with my fingers, and nibbling at them with its teeth like a little dog; leaping on my head and on my neck, and then running round my arm, with the softness and elegance of a squirrel. Such is its agility, that it will leap into my hands, although upwards of a yard distant, if I present them to it. It exhibits much adroitness and cunning to obtain any wished-for object; and it is 
so capricious at times, as to perform certain acts apparently from contradiction. It seems at all times exceedingly desirous of being noticed, watching my eye during all its little pranks, to see if I observe it. If I am inattentive to its sports, it seems to have no pleasure in them, immediately desists, and lays itself down to repose. It is so lively, that the moment I awake it, however sound its sleep may be, it instantly resumes its gambols with as much spirit as before it slept. It never is out of temper, except when much teazed, or when under confinement, which it detests; in which case it displays its displeasure by a kind of low murmur, quite opposed to the sound of its voice when pleased.

"This little creature can distinguish my voice amid twenty others, and springs over every one in the room till it has found me. Nothing can exceed the lively and pleasing way it caresses me with its two little paws: it frequently pats me on the chin, in a manner that expresses the utmost fondness. This, with a thousand other kindnesses, convinces me of the sincerity of its attachment. He is quite aware of my intention, when dressed to go out, and then it is with much difficulty I can rid myself of him. On these occasions he will conceal himself behind a cabinet near 
the door, and spring on me as I pass with astonishing quickness.

" His vivacity, agility, and voice, with the manner he utters it, have a strong similitude to those faculties in a squirrel. In the summer season he runs about all night, squeaking; but, since the cold set in, he has desisted from this practice, but has sometimes expressed this particular sound when rolling on my bed in the sunbeams.

" It seems exceedingly probable that the weasel sips the dew, judging from the remarkable manner he drinks milk from my hand. He will never drink water when he can get milk, and then in such a small way, that he appears to do it only to cool his tongue, for he evinced fear on several occasions, when water was presented to him. During the summer showers, I caught some rain-water, and endeavoured to get him to enter it to bathe himself, but this he would not do. I then dipped a piece of linen cloth in it; this seemed to afford him much pleasure, by rolling himself over it, which he did frequently.

"The curiosity of this little pet is unbounded, for it is impossible to open a box or drawer, without his roving through every part of them; if even a piece of paper or a book is looked at, he will also examine it 
with attention. Every thing I take into my hand he must run up to, and survey with an attentive scrutiny. I have a young dog and a cat, with both of which he is very familiar; he will scamper over their necks, backs, and legs, without their offering him the smallest injury." 


\section{THE STOAT.}

THIs animal, which is found in England, abounds in Norway, Lapland, and other parts of the north. It is a full third larger than the weasel.

One fact in reference to it suggests the benevolence of God, in adapting his creatures to their circumstances. In hot countries many animals have but little hair on their bodies, and some are almost entirely destitute of it. Of this the elephant will occur as an example. In very cold countries the fur, as well as the hair, is, on the contrary, unusually thick, and even the feet of some birds are covered with feathers, not only for the sake of protection, but to enable them to run more readily on the snow.

For the stoat, however, another provision is made : it undergoes in winter a remarkable change of colour. The whole of the coloured parts of the fur become of the purest white, excepting the extremity of the tail, which continues black, and the under parts retain a slight 
tinge of yellow. It appears that the animal does not actually lose its summer coat, for which a winter garment is substituted, but that there is an actual change of colour in the existing fur. The transition from one state of the coat to another does not take place, however, through any gradation of shade in the general hue, but by patches here and there of the winter colour, intermixed with that of the summer, giving, says Mr. Bell, a pied appearance to the animal.

In the Alpine districts of Scotland, and in northern latitudes generally, this change is universal, but southward it occurs occasionally, and even rarely. In Northumberland, and other counties in the north of England, it is very frequent; in the midland counties it is sometimes seen, and it has been observed more than once in Cornwall. This remarkable alteration of colour appears to be primarily occasioned not by the mere advance of the season, but by actual change of temperature. Even in a mild winter, the stoat has been observed with its garment changed; but as the hills were its dwelling place or frequent haunt, the coldness of the atmosphere on so elevated and bleak a spot as the moorland to which the animal was seen making its way, satisfactorily accounts for the whiteness of its fur.

The end designed by this transition is not beyond 
our reach. - It is doubtless partly intended to provide for the animal's safety, by an approach to the colour of the earth's clothing in winter. But it is also evident that the radiation, or passing off, of heat is much greater from dark than light coloured surfaces, and therefore that the animal heat from within is more fully retained by a white than a dark covering. The temperature of an animal having white fur, consequently continues more equable than that of one clothed in darker colours, though the latter will enjoy a greater degree of warmth whilst exposed to the rays of the sun. How beautiful then is the Divine arrangement, by which, when it is cold enough to prove hurtful, if not fatal to the animal, this very change of temperature is made to produce such an alteration in its condition, as shall effectually prevent the suffering of injury! Here it is manifest, as it is in other numberless instances, "that the Lord is good, and his tender mercies are over all his works." 


\section{THE FERRET.}

The ferret is a native of Africa, and has been employed in Britain and other countries of Europe, chiefly to reduce the number of rabbits, and to destroy rats. Its fur is of a yellowish hue, and its eyes are red. During the day it generally sleeps, and it feeds at night.

To the rabbit it has an instinctive antipathy. It is said, if a dead one be shown to a young ferret which has never before seen the animal, it seizes it; and if a live one be set before it, it displays still greater eagerness, laying hold of its neck, and continuing to suck the blood of its prey till completely satiated. When put into a burrow, it is usual to tie a bell round the neck of the ferret, to prevent its being lost, and to know where he is. Small nets are also placed over all the holes which are supposed to communicate with the one he has entered. If half-grown rabbits are to be taken from holes known to have few angles, and not to go far below the surface, the ferret is sometimes left unmuzzled, with a 
line round him, and as soon as he is thought to have seized the rabbit, he is drawn gently back with his prey in his mouth.

So intent are ferrets on their prey, that they have been known to disengage themselves from their muzzles, to remain in the holes, and only to be got out by digging for them, or smoking them. Both these methods have even been resorted to without effect, and the animal has kept its retreat good for the summer, and lived by preying on the rabbits; but when the winter sets in, these creatures either perish from cold, or leave the hole, and are then easily retaken.

Farmers, and other persons, frequently keep ferrets, for the purpose of killing rats, which they pursue with great activity and eagerness. Few of these creatures can escape such foes. It is said, indeed, that a ferret, even when young, will so tenaciously hold a rat he has seized, as to suffer himself to be dragged a considerable distance before he can kill his prey; but this is generally done at last.

Although easily tamed, the ferret seldom shows any attachment, and is very easily irritated. One instance may be mentioned of its singular ferocity, when tempted by opportunity, or excited by the smell or taste of blood. A bargeman of the name of Isles, finding himself much 
incommoded by the mischief done in his barge by rats, procured a ferret to destroy them. The ferret remaining away a considerable time, he thought it was devouring some rats that it had killed, and went to sleep; but was awakened early next morning by the ferret, who had commenced a regular attack upon him. The animal had seized him near his eye-brow; and the man, after endeavouring in vain to shake him off, at length severed the body from the head with a knife, - the teeth still sticking so fast, that the head was with diffculty removed. 


\section{THE MARTEN.}

- The structure of martens has been noticed, as appropriately distinguishing them from weazels. They creep from branch to branch, silently pursuing their prey, consisting of birds, squirrels, and other small animals, and hence their sharp and long claws provide a firm and secure hold of the bark, and their long and somewhat bushy tails help them to keep their balance on the boughs, while their large and open ears aid them in chasing the objects of pursuit amidst the dense foliage in which they love to be concealed. Weazels are designed to pursue animals on the ground, in burrows, and in similar places of retreat, while martens are as obviously prepared for living in trees. The exceptions afforded by the habits of particular individuals do not affect these general remarks.

The common and the pine marten are, on the upper parts, of a dark chestnut colour. The former is white on the throat and breast; the latter yellow. Their 
general retreat is the hollow in the upper part of some decayed tree. They prefer the place chosen for the nest of a squirrel, and having killed the inhabitant, the new tenant enlarges it, and lines it with softer materials. Though ferocious in disposition, these creatures are easily tamed. Gesner kept a pine marten, which used to go to the houses of the neighbours, but always returned home when wanting food. It was very fond of a dog with which it had been bred up, and would play with it as cats do, lying on its back, and pretending to bite.

Buffon also had one which, though it had lost its ferocity, did not discover any marks of attachment, and continued so wild as to require being chained. It, however, frequently escaped from its confinement. At first, after being absent some hours, it returned, but without seeming pleased; the time of remaining away gradually increased, and at last it took its final departure.

In some countries the marten is eagerly pursued, from its skin being valued for the fur; it is in great request for lining and trimming the robes of magistrates, as well as for other purposes. It is particularly admired in Turkey, into which it is imported, chiefly from Sicily and France. A large 


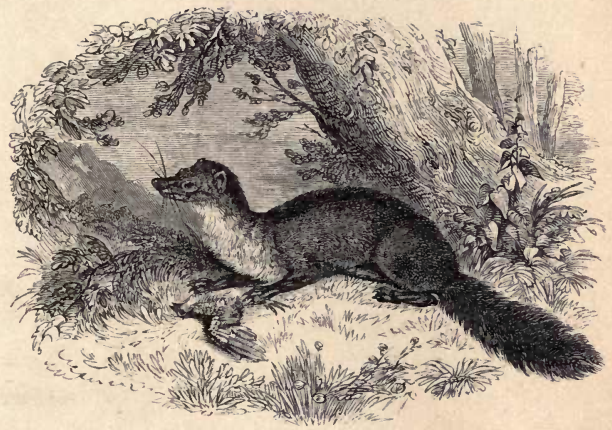

THE MARTEN. 
number of these skins are also received in this country from Hudson's Bay and from Canada; the most valuable part being that which extends along the middle of the back. 


\section{THE HOG.}

THE domestic hog is usually, as to colour, of a dirty white, but some are pied, and others altogether black. This animal, which is generally harmless and inoffensive, lives chiefly on vegetables. It is descended from a race still wild in the larger forests of Europe and Asia, and the northern parts of Africa.

In Minorca, the hog is converted into a beast of draught; a cow, a sow, and two young horses, have been seen in that island yoked together; and of the four, the sow drew the best. The ass and the hog are here common helpmates, and are frequently yoked together to plough the land. In some parts of Italy, swine, according to Bayley, are used in hunting for truffles, which grow some inches deep in the ground. A cord being tied round the hind-leg of one of these animals, the beast is driven into the pastures, and it is said, that wherever it stops, and begins to root with its nose, truffles are always to be found. 


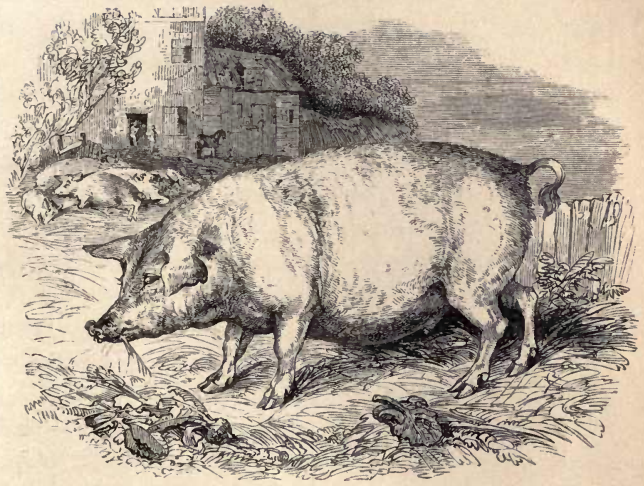

THE HOG. 

In several counties of England great attention has been given to breeding pigs, but the inland, north-west, and north-east districts have generally had the largest swine. The woods of the New Forest afford excellent food for hogs, which are led in autumn into many parts of the forest to fatten on mast. The method of treating them at this season, and especially of reducing them to order and obedience, is not a little curious. The swineherd first chooses some closely sheltered spot, having water and plenty of oak or beech-mast, but the former, if sufficiently abundant, he considers preferable; and then finds some spreading tree, round the bole of which he wattles a slight circular fence, and covering it roughly with boughs and sods, he fills it plentifully with straw or fern.

$\mathrm{He}$ now collects his colony among the farmers, which amounts perhaps to five or six hundred hogs; drives them to their habitation, gives them a plentiful supper of acorns or beech-mast, which he had provided, and sounds his horn during the repast. He then turns them into the litter, where, after a long journey and a hearty meal, they sleep soundly, The next morning he lets them look a little about, shows them the pool or the stream where they may occasionally drink, leaves them to pick up the remains of the last night's meal, 
and as evening advances, gives them another plentiful repast under the neighbouring trees, at the sound of his horn, and then sends them again to sleep.

$\mathrm{He}$ is, perhaps, at the trouble of procuring them another meal, with music playing as usual, the following day. He then leaves them a little more to themselves, watching them, however, in their evening hours; but as they eat much, they seldom wander far from home, and commonly return very orderly and early to bed. After this he throws his sty open, leaves them to cater for themselves, and usually has little more trouble with them. Now and then, in calm weather, when mast falls sparingly, he perhaps calls them together by his horn to a gratuitous meal ; but generally they need little attention, returning regularly home at night, though they often wander two or three miles from the sty.

The animals forming the herd are by this management sent to their respective owners in such condition, that they may be quickly and easily fattened. It is observed, whatever is their number, that they generally separate in their daily excursions, into such little parties as have formerly been intimate; and in these friendly groups they range the forest, returning home at night in different parties, some earlier, and others later, as they have been more or less successful in the pursuit 
of food. "You see them," says Gilpin, "perfectly happy, going about at their ease, and conversing with each other in short, pithy, interrupted sentences, which are no doubt expressive of their own enjoyments, and of their social feelings."

To the cottager the pig is often, when properly managed, a very valuable animal. Pork, of all meat, is best adapted to curing and preservation with salt; and it is said that men will subsist longer upon it, without desire of change, than upon any other flesh. In many parts of the country, labourers rarely taste any other, and generally eat it with great relish.

Pigs readily adapt themselves to change. Thus, if the weather be hot, they cover themselves with mud, probably that they may be freed from vermin, or that flies may be kept off. When the weather is about to alter, they may often be observed running at full speed from a field where they had been before quietly feeding, and making an outcry the whole way to their sties. Impatient of cold, they collect straw in their mouths, and carry it under a shed in the yard, appearing to invite their companions, who are not so employed, to assist in the task, and towards night all will nestle together, after a struggle for the warmest place.

Selfish and rapacious as the hog is often thought, no 
animal has greater sympathy for those of his own kind. "The moment one of them," says Bingley, "gives the signal of distress, all within hearing rush to his assistance. They have been known to gather round a dog that teazed them, and kill him on the spot. Enclose a male and female in a sty when young, and the female will decline from the instant her companion is removed, and will probably die of sorrow."

Nor are cases wanting in which there has been some display of sagacity. The writer remembers a pig belonging to a family with which he is well acquainted. It had a sty with a door having a latch, which was sometimes thrown open; but the sagacious quadruped within did not choose to be limited to such occasions. He might often be seen with his fore-feet on the upper of two rails placed just within his abode, having unlatched the door with his snout, and thrown it back, that he might look about the garden before his dwelling, and inhale at another opening its pleasant air.

Captain Hall describes a pig as petted by the sailors; it was named Jean, and would come to those who called it. He at first doubted the fact, but one day going on deck, he called out, "Jean! Jean!" and in a moment the delighted pig came prancing along; and so eager 
was the animal, that she nearly overthrew an officer in her passage.

Sharon Turner mentions his seeing a large pig at Ross, which, at the word of command, could pick out from an alphabet on the ground, and that without mistake, the name of any person present, and also the figures for the hour of the day. It went round a paper dial on the floor, and placed its snout first on the hour, and then in another circuit on the minute. "There was," says Mr. Turner, "no visible concert that I could trace between it and its master, so that the assisting tokens were the more intellectual. The owner mentioned that being more dull at learning than some, it had taken him three months' close labour to teach him." No doubt it was directed by some signs made by its owner.

The writer has often visited a village in Wiltshire, where a pig was made to answer the purposes of its master in a different way. This man allowed the animal to get its living as it could, and consequently it frequently did so at the cost of those who were near. On one occasion, however, the depredator was caught in the fact, and shut up in the pound. A short time after, a busy neighbour went to the owner with the tidings; the answer he received was brief: "I know it, and I 
will give her her supper presently." Soon after he sallied forth, and did what he had promised himself, by severely whipping the pig, and leaving it for the night without food.

The next morning it was again stated that his pig was in the pound, and he replied that he would soon go and give her a breakfast; but fulfilling his word in precisely the same manner as he had adopted on the former night. Several hours now elapsed, and once more he heard of the incarceration of his pig, when, with equal coolness, he said she should speedily have her dinner, which proved to be only a third castigation. He now, however, paid the dues, and the animal was liberated. The reader, perhaps, can predict the result; from that day forward the pig roamed about and fed wherever she pleased, nor was it ever in the power of the villagersand the experiment was tried more than once-to put her again into the pound. The crafty and dishonest owner calculated on her power of recollection, and that with the utmost effect.

It would seem, moreover, that this animal is sometimes capable of strong attachment to man. Lockhart, the biographer of Sir Walter Scott, describes a large party as ready to set out from Abbotsford on horseback; and " the sociable," he says, "was just getting under weigh," 
when one of the Miss Scotts broke from the line, and laughing heartily, exclaimed, "Papa! papa! I knew you would not think of going without your pet." Scott looked round, when he perceived a little black pig frisking about his pony, and evidently intending to make one of the party. His wish was, however, not gratified. The fact was, that the pig had taken, nobody could tell how, a strong attachment to Scott, and was constantly anxious to join the greyhounds and terriers that accompanied him in his rambles.

In one of the South Sea Islands, it was stated by the late Mr. Williams, that pigs are very numerous, and that the natives gave the names of these animals to others when procured by him from an American ship. The horse was called the great pig that carries the man, the dog the barking pig, and the ass the noisy or the long-eared pig.

A truly interesting fact, in connexion with this animal, is mentioned by the same missionary. During one of his visits to the island of Aitutaki, he explained to the people one evening the manner in which English Christians raised money to send the Gospel to heathen countries. On hearing this they expressed their regret at not having money, that they might also enjoy the privilege of " helping in the good work of causing the 
word of God to grow." "I replied," he says, " "If you have no money, you have something to buy money with.' This idea was quite new to them, and they wished to know at once what they possessed which would buy money. I said to them, 'The pigs I brought to your island, on my first visit, have multiplied so greatly, that all of you have an abundance; and if every family in the island were to set apart a pig " for causing the word of God to grow," and when the ships come, to sell them for money instead of cloth and axes, a valuable contribution might be raised.' The idea delighted them exceedingly, and early the next morning the squeaking of the pigs, which were receiving a particular mark in the ear for this purpose, was heard from one end of the settlement to the other. In the interim, a ship had been there, the captain of which had purchased their pigs, and paid for them most honourably; and now, to my utter astonishment, the native treasurer put into my hands $103 l$., partly in bills, and partly in cash. This was the first money they ever possessed, and every farthing of it was dedicated to the cause of Christ." 


\section{THE RABBIT.}

THe keeping of rabbits is the frequent amusement of children and young persons in this country. It is, at least, an innocent one, and it may exert a beneficial influence on the mind. So much cannot be said for many employments of our early days, nor, unhappily, for some of riper years. And yet, the character and effect of all our occupations ought to be ascertained, with the solicitude not only to obey the charge, "Cease to do evil," but that which requires us also to abstain from its " appearance."

The rabbit, though resembling the hare in some respects, is easily distinguishable from it. It is different from that animal in habit, as well as in form. Unequal to that rapid course for which the hare is adapted, it digs deep holes for shelter and safety, and enjoys the society of its fellows in spots where food is provided. The ground of a warren, and sometimes to a great extent, is pierced all about with deep holes. The 
gambols of its little tenants, as they play in security, or their rapid flight from any cause of alarm, are not a little amusing. They commonly remain in their burrows during the day, and come forth about twilight to feed. In doing so, they are not unfrequently mischievous, eating the bark of young trees, and the corn when first springing up.

The care with which the rabbit provides for her young is very remarkable. Not only does she make a nest of the softest hay, from which she carefully removes all the harder portions, but she actually strips the fur, or down, from her own breast, that it may be made still more agreeable. At first she covers up her young with the same materials, in order to keep them warm : uncovering them only when it is necessary. This provision is, moreover, nicely adapted to the state of the weather, and the strength of her progeny, and is gradually diminished as they become more robust.

A gentleman, who had amused himself with raising rabbits for many years, says :- “ I began with only one male and one female, the former white, the latter grey ; and of their produce, which was very numerous, the greatest part were grey, a good number of them white, and of a mixed colour, and some few black. These animals seem to have a great respect for paternal 


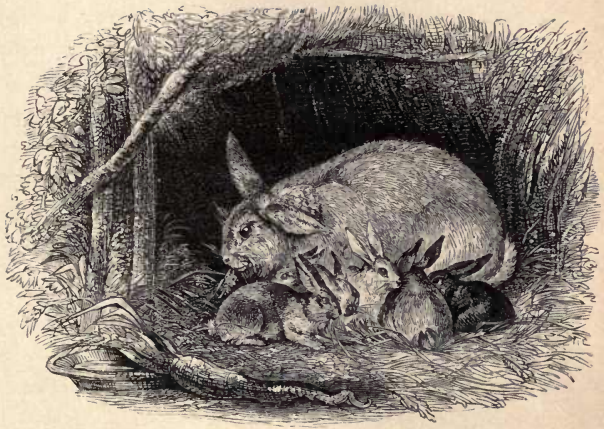

THE RABBIT. 


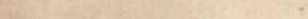

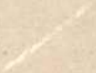


authority; at least, I judge so, from the great deference which all my rabbits showed for their first ancestor, whom I can always easily distinguish by his whiteness, and who, indeed, is the only male of that colour which I have preserved. It was to no purpose the family augmented ; those which, in their turn, became fathers, were still subordinate to him. Whenever they fought, whether on account of their females, or concerning their food, their great progenitor would run to the place of dispute with all speed, as soon as he heard the noise. No sooner did they perceive him, than everything was presently reduced to order : and if he surprised any one of them actually assaulting another, he used to separate him from the rest, and punish him on the spot. Another proof of his dominion over all his posterity is, that they were accustomed to return at a whistle, whenever I gave the signal, how distant soever they might be; this old one immediately put himself at their head; and though he came first, yet he made them all file off, and enter before him; nor would he go in till the last."

It appears that the rabbit can sometimes display a high degree of courage. To quote the words of Mr. Howitt:- “I was, on a fine summer's day, sitting in the meadows opposite Tutbury Castle, in Stafford- 
shire, contemplating the remains of that fabric, which once imprisoned the Queen of Scots. On the slope of the Castle-hill facing me, I observed a rabbit sitting by its burrow. Suddenly, from a bush, at some distance, issued a large weazel, and darting on with the rapidity of an arrow, attempted to make its way into the burrow, in which, no doubt, were the rabbit's young ones. The rabbit, with an air of the utmost coolness, raising itself as the weazel approached, received him with several smart thumps upon the head. He fled back, but speedily renewed the attack, and was received in the same style. The assault, battery, and retreat were maintained for at least a quarter of an hour, when the weazel crawled away, apparently exhausted, and appeared no more. Such is the valour infused by parental instinct into the most weak and timid creatures."

The rabbit is valued as an article of food, and also for its fur. For the sake of its covering, multitudes of rabbits are bred in various parts of Europe, and from these our country is supplied, as well as from its own produce. In a domestic state these animals lose, in some degree, their instinct of burrowing; yet if several are kept together in a convenient place, they will show that it is not altogether extinct. In 
one breed the ears droop so much, that they touch the ground when the animal is feeding; and among the most esteemed varieties are the Half-lop, the Horn-lop, the Oar-lop, and the Perfect-lop. 


\section{THE HARE.}

THIs animal, whose form and hue are so well known, has many enemies. Quadrupeds and birds of prey are numbered among them, while man often amuses himself by the chase, which fills it with terror, and terminates its life. True, indeed, are the well-known words-

" Poor is the triumph o'er the timid hare !

Yet vain her best precaution, though she sits

Concealed, with folded ears, unsleeping eyes,

By nature raised to take the horizon in,

And head concealed betwixt her hairy feet,

In act to spring away."

We will not describe the cruel pastimes of hunting or coursing the hare. Her danger is constant, though she has eyes which are so prominent that they can see all around; ears which are moveable, and can catch a distant sound, and feet endued with extraordinary swiftness. Still- 


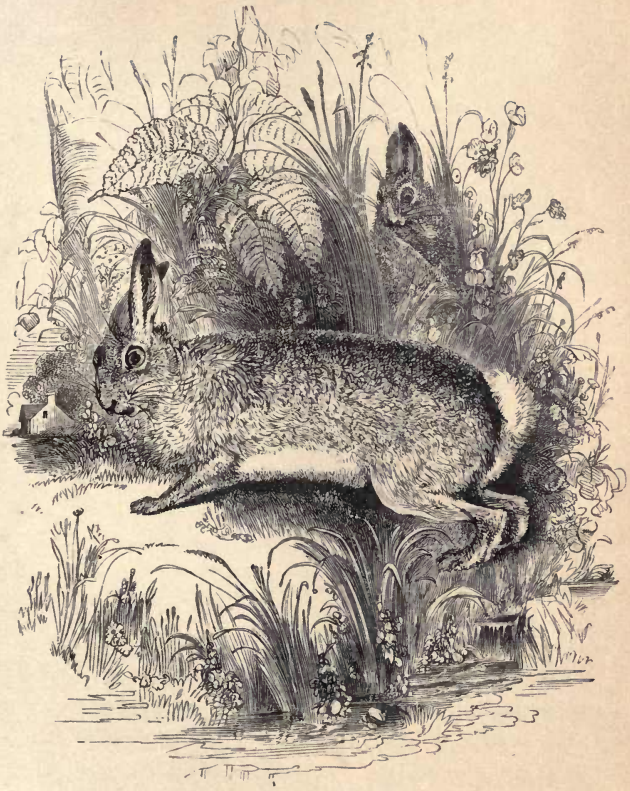

THE HARE. 
"The scented dew

Betrays her early labyrinth: and deep

In scattered sullen openings, far behind,

With every breeze, she hears the coming storm;

But nearer, and more frequent, as it loads

The sighing gale, she springs amazed, and all

The savage soul of game is up at once."

The hare is capable of domestication. One, it is said, became so familiar as to feed from the hand, lie under a chair in a common sitting-room, and appear in every other respect as easy and comfortable as a lapdog. Now and then it went into the garden, but after regaling itself always returned to the house as its proper habitation. Its usual companions were a grey-hound and a spaniel, both so fond of hare-hunting that they went out together, without the company of any person. The tame hare spent its evenings with these two dogs; they always slept on the same hearth, and very frequently it would rest itself upon them.

The most interesting account, however, ever yet penned, of domesticated hares, is the following, by our eminent and Christian poet Cowper:- "I undertook," he says, "the care of three, which it is necessary that I should here distinguish by the names I give themPuss, Tiney, and Bess. Notwithstanding the two feminine appellatives, I must inform you that they were all 
males. Immediately commencing carpenter, I built them houses to sleep in; each had a separate apartment, so contrived that their ordure should pass through the bottom of it; an earthen pan placed under each received whatever fell, which being duly emptied and washed, they were thus kept perfectly sweet and clean. In the day time they had the range of a hall, and at night retired each to his own bed, never intruding into that of another.

"Puss grew presently familiar, would leap into my lap, raise himself upon his hinder feet, and bite the hair from my temples. He would suffer me to take him up, and carry him about in my arms, and has more than once fallen fast asleep upon my knee. He was ill three days, during which time I nursed him, kept him apart from his fellows, that they might not molest him, (for, like many other wild animals, they persecute one of their own species that is sick,) and by constant care, and trying him with a variety of herbs, restored him to perfect health. No creature could be more grateful than my patient after his recovery; a sentiment which he most significantly expressed by licking my hand, first the back of it, then the palm, then every finger separately, as if anxious to leave no part of it unsaluted; a ceremony which he never performed but once 
again upon a similar occasion. Finding him extremely tractable; I made it my custom to carry him always after breakfast into my garden, where he hid himself generally under the leaves of a cucumber vine, sleeping or chewing the cud until evening; in the leaves also of that vine he found a favourite repast. I had not long habituated him to this taste of liberty, before he began to be impatient for the return of the time when he might enjoy it. He would invite me to the garden by drumming upon my knee, and by a look of such expression as it was not possible to misinterpret. If this rhetoric did not immediately succeed, he would take the skirt of my coat between his teeth, and pull at it with all his force. Thus Puss might be said to be perfectly tamed, the shyness of his nature was done away, and, on the whole, it was visible by many symptoms which I have not room to enumerate, that he was more happy in human society than when shut up with his natural companions.

"Not so Tiney; upon him the kindest treatment had not the least effect. He, too, was sick, and in his sickness had an equal share of my attention; but if, after his recovery, I took the liberty to stroke him, he would grunt, strike with his fore-feet, spring forward, and bite. He was, however, very entertaining in his way; even 
his surliness was matter of mirth, and in his play he preserved such an air of gravity, and performed his feats with such a solemnity of manner, that in him too I had an agreeable companion.

"Bess, who died soon after he was full grown, and whose death was occasioned by his being turned into his box, which had been washed, while it was yet damp, was a hare of great humour and drollery. Puss was tamed by gentle usage; Tiney was not to be tamed at all; and Bess had a courage and confidence that made him tame from the beginning. I always admitted them into the parlour after supper, when the carpet affording them a firm hold, they would frisk, and bound, and play a thousand gambols, in which Bess, being remarkably strong and fearless, was always superior to the rest, and proved himself the chief of the party. One evening, the cat, being in the room, had the hardiness to pat Bess on the cheek, an indignity which he resented by drumming upon her back with such violence, that the cat was happy to escape from under his paws, and hide herself.

"I describe these animals as having each a character of his own. Such they were in fact, and their countenances were so expressive of that character, that, when I looked only on the face of either, I immediately knew 
which it was. It is said that a shepherd, however numerous his flock, soon becomes so familiar with their features, that he can, by that indication only, distinguish each from all the rest; and yet to a common observer, the difference is hardly perceptible. I doubt not that the same discrimination in the cast of countenances would be discernible in hares, and am persuaded that among a thousand of them no two could be found exactly similar; a circumstance little suspected by those who have not an opportunity to observe it. These creatures have a singular sagacity in discovering the minutest alteration that is made in the place to which they are accustomed, and instantly apply their nose to the examination of a new object. A small hole being burnt in the carpet, it was mended with a patch, and that patch in a moment underwent the strictest scrutiny. They seem to be very much directed by the smell in the choice of their favourites : to some persons, though they saw them daily, they could never be reconciled, and would even scream when they attempted to touch them; but a miller coming in engaged their affections at once; his powdered coat had charms that were irresistible. It is no wonder that my intimate acquaintance with these specimens of the kind has taught me to hold the sportsman's amusement in abhorrence; he little knows what 
amiable creatures he persecutes, of what gratitude they are capable, how cheerful they are in their spirits, what enjoyment they have of life, and that impressed as they seem with a peculiar dread of man, it is only because man gives them peculiar cause for it.

"Bess, I have said, died young; Tiney lived to be nine years old, and died at last, I have reason to think, of some hurt in his loins by a fall ; Puss is still living, and has just completed his tenth year, discovering no signs of decay, nor even of age, except that he is grown more discreet and less frolicksome than he was. I cannot conclude without observing, that I have lately introduced a dog to his acquaintance; a spaniel that had never seen a hare, to a hare that had never seen a spaniel. I did it with great caution, but there was no real need of it. Puss discovered no token of fear, nor Marquis the least symptom of hostility. There is, therefore, it should seem, no natural antipathy between dog and hare; but the pursuit of the one occasions the flight of the other, and the dog pursues because he is trained to it; they eat bread at the same time out of the same hand, and are, in all respects, sociable and friendly. Puss died of old age, when she was within a month of her twelfth year.

"I should not do complete justice to my subject, did 
I not add, that they have no ill scent belonging to them ; that they are indefatigably nice in keeping themselves clean, for which purpose nature has furnished them with a brush under each foot; and that they are never infested by any vermin."

Some years ago there was seen in the streets of London, a hare, which moved fearlessly about upon a table, in the midst of the noise of a hand-organ, and of a multitude around. It was taught to beat a tambourine with great rapidity, to pull a trigger, and thus to discharge a pistol. Its docility will appear remarkable, when it is remembered that the hare is one of the most timid of animals.

These creatures pass their days in solitude and silence, but occasionally assemble by moonlight, and sport together, when they think themselves safe from annoyance. Yet a falling leaf will disturb them, and cause them to scamper off in different directions.

\section{THE ALPINE HARE.}

The Alpine hare makes no burrow like the rabbit, but hides under stones, or in the clefts of rocks, and it 
has not the swiftness of the common species. As the winter draws on, it leaves its high mountain residence, and descends to a warmer and more genial climate. Its fur now undergoes a change as complete as that of the ermine ; it becomes gradually, and at length wholly, white, only excepting the lips and the tips of the ears, which always remain black.

There is no change of its coat in the autumn, but the grey fur is whitened in patches, until it has altogether undergone this alteration in colour. This continues during the whole winter, and in the spring the white fur is thrown off, and a new coat makes its appearance.

In Scotland the change thus proceeds. About the middle of September the grey feet begin to be white; and before the month ends, all the four feet are white, and the ears and muzzle of a brighter colour. The white colour gradually ascends the legs and thighs, and under the grey hairs whitish spots are observed, which continue to increase till about the middle of October; but still the back continues of a grey colour, while the eyebrows and ears are nearly white. From this period, the change proceeds very rapidly; and by the middle of November, the whole fur, with the exception of the tips of the ears, is of a shining white. The back becomes white within eight days. During the whole of 
this remarkable change in the fur, no hair falls from the animal; hence it appears that the hair actually changes its colour, and that there is no removal of it. The fur retains its whiteness till the month of March, or later, according to the temperature of the atmosphere; and by the middle of May it has again a grey colour. 


\section{THE DORMOUSE.}

ALL the species of dormice live in holes in the ground, where they remain during the winter in a state of torpor. Their food consists entirely of vegetables, and they eat only in the night. In doing so they sit upright, and feed themselves like squirrels with their paws. These animals collect little stores of nuts, acorns, and other food for their winter provision. The nest is commonly formed in the hollow of some low tree, or near the bottom of close shrubs, of interwoven grass, dead leaves, and moss. It has a small opening near the top, for the ingress and egress of the animal. Retiring to their holes on the approach of the cold, and rolling themselves up, dormice lie torpid nearly all the winter, and therefore consume but little of the hoard which they have diligently laid up. In a warm sunny day they revive for a short time, take a little food, and soon relapse into their former state.

In the third volume of the "Naturalist," Mr. Salmon gives the following account of a dormouse which he 
happened to capture on the 16 th of December, 1837 :

"As I was pushing my way amidst the briers and brambles, I chanced to stumble upon an interesting incident, in the shape of a little ball of grass curiously interwoven, lying on the ground. It was about eight inches in circumference, and on taking it up I soon ascertained, by the faint sound emitted from the interior, on my handling it, that it contained a prisoner. I bore my prize homeward for examination, and on making a slight opening, immediately issued forth one of those beautiful little creatures, the dormouse. The heat of my hand, and the warmth of the room, had completely revived it from its torpor ; it appeared to enjoy its transition by nimbly scaling every part of the furniture in all directions. It experienced no difficulty in either ascending or descending the polished backs of the chairs; and when I attempted to secure it, it leaped from chair to chair with astonishing agility for so small a creature. On taking it into my hand, it showed not the least disposition to resent the liberty; on the contrary, it was very docile. On being set at liberty, it sprang at least two yards on to a table. I was much gratified on witnessing its agile movements. In the evening I placed my little stranger with its original domicile in a box, of which, on the following morning, I found it had 
taken possession, and again relapsed into a state of torpidity, in which condition I transferred my unconscious sleeper to a friend."

In the same volume, Mr. Pigot, Stoke Ferry, Norfolk, states that it came to him from Sussex, on the 23rd of December, "a distance of 140 miles, apparently but little disturbed by the long and tedious ride. From that time, till the 1st of April, 1838," he says, "it slept in its snug dormitory, a deal box lined with wool, when it awoke, and readily ate of apples and nuts. It is easily alarmed, being more timid than tame, but shows no signs of anger on being taken in the hand. As it sleeps the greater part of the day, I cannot then closely watch its habits; but towards evening it wakes up, and is very lively and frolicsome, running, on being let out of its cage, up the bell-rope, where it will sit for hours in the folds of the knot, timidly watching our movements." 


\section{THE MOUSE.}

How strange that any one should feel repugnance to this delicate little creature! Its natural timidity might indeed plead for it; not merely a glance at an object, but even a slight sound will frequently cause its immediate retreat. It is associated, however, in the mind with domestic troublers; and, in many cases, it would be very difficult, or absolutely impossible, to awaken another and a different state of feeling; while the mouse cannot be allowed to increase unmolested.

In some cases it becomes formidable from its numbers. Mr. Jesse states, that a few years ago, some new plantations were made, by order of the Crown, in Dean Forest, Gloucestershire, and in the New Forest, Hampshire. Soon afterwards there was so sudden and rapid an increase of mice, as to threaten destruction to the whole of the young plants. As the mice eat through the roots of five-year old oaks and chestnuts, generally below the surface of the ground, vast numbers of them 
were killed. Hollies, five or six feet high, were barked round the bottom; and, in some cases, the mice had climbed the trees, and were seen feeding on the bark of the upper branches. The roots were eaten through wherever they obstructed the runs of the mice, but the bark formed their food.

Traps were set, poison laid, and cats turned out, yet their number appeared not lessened. In some of the Dean Forest plantations holes were therefore made, about twenty yards asunder, and as many inches deep; they were much wider at the bottom than at the top, being hollowed under, so that the animal, when once in, could not easily get out again. In these holes at least 30,000 mice were caught in the course of three or four months; and it was also calculated, that a much greater number than this were taken out of the holes after being caught, by stoats, weazels, kites, hawks, and other birds and quadrupeds.

Sometimes the mouse discovers no inconsiderable ingenuity. A few years ago, for instance, the Rev. Mr. North, the rector of Ashdon, in Essex, placed a pot of liquid honey in a closet where there was plaster rubbish, it having been recently built. After some months, he went to the closet for some honey, and was struck with the appearance of a mound of rubbish, against the 
side, and nearly to the top of the pot. He delayed removing it, till he had considered what could be its cause, the closet having been locked up. On setting a trap, he caught a mouse, which proved to be the culprit. On examining the honey, it appeared to have been raised to the top of the vessel by means of throwing in rubbish of the same material as the mound, and with which the pot was nearly filled.

The following circumstances lead to the conclusion, that one mouse, at least, had no instinctive dread of a cat. This creature, caught in the gallery of a coalmine, into which no cat had been admitted, was taken home by the finder, who wished to observe its movements. That it might regain its self-possession, after being brought into the light of day, which, in all probability, it had never seen before, it was kept for a few days confined in a glass lantern, where it soon became so tame, that it would eat in the presence of its host. That it might look more fully about, a piece of stick, about nine inches long, was fixed into the socket of the lantern, on which the mouse very soon mounted; and after finishing its meals, it found amusement on its perch, by licking all the accessible parts of its body.

While thus engaged, on the fifth or sixth day of its 
capture, a young cat was let into the room, and soon discovering the lantern, which was placed on a table, and also its captive, she dashed at it with the ferocity of a tiger. But notwithstanding this furious attack, the mouse continued its ablutions with the greatest coolness. This experiment was repeated, and always with the same result, when he was carried to the mine, and restored to liberty.

The sensibility of mice to music is not a little remarkable. Of this some of our readers may occasionally have had proofs. As a member of the family has been performing on the piano-forte, mice may have been observed coming forth from the wainscoting of the room, and showing great attention to the sound. In some instances the effect produced by music on these animals is very great. Thus, " on a rainy evening in 1817," says Dr. Archer of Norfolk, in the United States, "as I was alone in my chamber, I took up my flute, and commenced playing. In a few minutes, my attention was directed to a mouse that I saw creeping from a hole, and advancing to the chair in which $I$ was sitting. I ceased playing, and it ran precipitately back to its hole. I began again shortly afterwards, and was much surprised to see it reappear, and take its old position. The appearance of the little animal was truly delightful; it 
couched itself on the floor, shut its eyes, and appeared in ecstacy. I ceased playing, and it instantly disappeared again. This experiment I repeated frequently with the same success, observing that it was always differently affected, as the music varied from the slow and plaintive to the brisk and lively. It finally went off, and all my art could not entice it to return."

A similar occurrence may also be mentioned. As on a winter's evening, at the close of 1817, a few officers on board a British man-of-war in Portsmouth harbour, were seated round the fire, one of them began to play a plaintive air on the violin. He had scarcely done so ten minutes, when a mouse, apparently frantic, made its appearance in the centre of the floor. Its strange gestures strongly excited the attention of the officers, who resolved that it should continue its singular movements unmolested. Its exertions now appeared greatly to increase; it shook its head, leaped about the table, and showed signs of the highest delight. In proportion to the gradation of the tones to the soft point, the feelings of the animal were observed to increase, while they declined when the contrary was the case. After performing actions of which, at first sight, it would seem incapable, the little creature suddenly paused, fell down, and expired without showing any symptoms of pain. 


\section{THE HARVEST MOUSE.}

THE harvest mouse is the smallest of British quadrupeds. It measures two inches and a quarter from the nose to the tail, and the tail two inches: two of them put into a scale weighed only about the third of an ounce avoirdupois.

This small species was first brought before the notice of the British naturalist, by the Rev. Gilbert White, of Selbourne, in Hampshire, whose interesting account is as follows:- "These mice are much smaller and more slender than the middle-sized domestic mouse of Ray, and have more of the squirrel or dormouse colour. Their belly is white. A straight line along their sides divides the shades of their back and belly. They never enter houses, are carried into ricks and barns with the sheaves, they abound in harvest, and build their nests amidst the straws of corn above ground, and sometimes in thistles. They breed as many as eight in a litter, in a little round nest, composed of the blades of grass or wheat. 


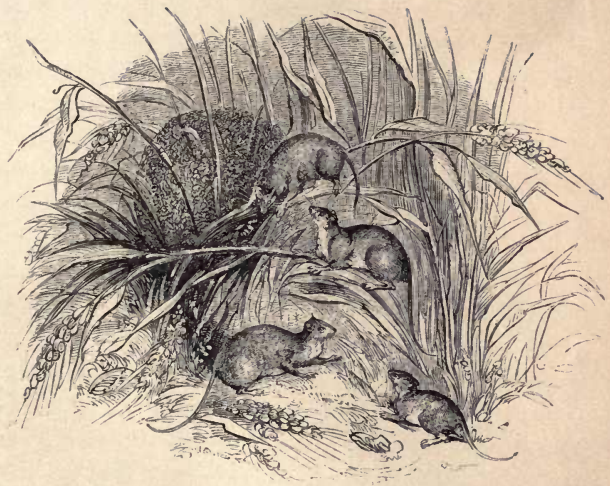

THE HARVEST MOUSE. 
t5

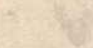


" One of these nests I procured this autumn (1767), most artificially platted, and composed of the blades of wheat, perfectly round, and about the size of a cricketball, with the aperture so ingeniously closed, that there was no discovering to what part it belonged. It was so compact and well filled, that it would roll across the table without being discomposed, though it contained eight little mice that were naked and blind. As this nest was perfectly full, how could the dam come at her litter respectively, so as to administer a teat to each? Perhaps she opens different places for that purpose, adjusting them again when the business is over; but she could not possibly be contained herself in the ball with her young, which, moreover, would be daily increasing in bulk. This wonderful procreant cradle, an elegant instance of the efforts of instinct, was found in a wheatfield, suspended in the head of a thistle."

In winter, the harvest mouse burrows deep in the earth, and makes a warm bed of grass ; but prefers congregating in immense numbers under the roof of corn or hay-stacks, when these are within its reach. The following interesting account of the habits of a tame mouse is by the Rev. W. Bingley, in his Memoirs of British Quadrupeds :- "About the middle of September, 1804, I had a female harrest mouse given to me. 
It was put into a dormouse cage immediately when caught, and a few days afterwards produced eight young ones. I entertained some hope that the little animal would have nursed these, and brought them up; but, having been disturbed in her removal, about four miles from the country, she began to destroy them, and I took them from her. The young ones, at the time I took them from her, were not more than two or three days old, and must have been at least equal in weight to the mother. After they were removed, she became reconciled to her situation; and, when there was no noise, would venture to come out of her hiding-place at the extremity of the cage, and climb about among the wires of the open part before me. In doing this, I remarked that her tail was prehensile, and that to render her hold the more secure she generally coiled the extremity of it round one of the wires. The toes of all the feet are particularly long and flexile, and she could grasp the wires very firmly with any of them. She frequently rested on her hind feet, somewhat in the manner of the jerboa, for the purpose of looking about her; and, in this attitude, could extend her body at such an angle as greatly surprised me. She was a beautiful little animal, and her various attitudes in cleaning her face, head, and body with her paws, were particularly graceful and ele- 
gant. For a few days after I received this mouse, I neglected to give it any water; but when I afterwards put some in the cage, she lapped at it with great eagerness. After lapping, she always raised herself on her hind feet, and cleansed her head with her paws. She continued, even till the time of her death, exceedingly shy and timid; but whenever I put into the cage any favourite food, such as grains of wheat or maize, she would eat them before me. On the least noise or motion, however, she immediately ran off with the grains in her mouth to her hiding place.

"One evening, as I was sitting at my writing-desk, and the animal was playing about in the open part of its cage, a large blue fly happened to buzz against the wires; the little creature, although at twice or thrice the distance of her own length from it, sprang along the wires with the greatest agility, and would certainly have seized it, had the space between the wires been sufficiently wide to have admitted her teeth or paws to reach it. I was surprised at this occurrence, as I had been led to believe that the harrest mouse was merely a granivorous animal. I caught the fly, and made it buzz in my fingers against the wires. The mouse, though usually shy and timid, immediately came out of her hiding-place, and, running to the spot, seized and 
devoured it. From this time, I fed her with insects whenever I could get them; and she always preferred them to any other kind of food I could offer her.

"When this mouse was first put into the cage, a piece of fine flannel was folded up in the dark part of it as a bed, and I put some grass and bran into the large open part. In the course of a few days, all the grass was removed; and, on examining the cage, I found it very neatly arranged between the folds of the flannel, and rendered more soft by being mixed with the nap of the flannel, which the animal had torn off in considerable quantity for that purpose. The chief part of this operation must have taken place in the night ; for although the mouse was generally awake and active during the day-time, yet I never once observed it employed in removing the grass.

"On opening its nest, about the latter end of October, 1804, I remarked that there were, among the grass and wool at the bottom, about forty grains of maize. These appeared to have been arranged with some care and regularity, and every grain had the circular or growing part eaten out, the lobes only being left. This seemed so much like an operation induced by the instinctive propensity that some quadrupeds are endowed with, for storing up food for support during the 
winter months, that I soon afterwards put into the cage about one hundred additional grains of maize. These were all, in a short time, carried away ; and, on a second examination, I found them stored up in the manner of the former. But, though the animal was well supplied with other food, and particularly with bread, which it seemed very fond of, and although it continued perfectly active through the whole winter, on examining its nest a third time, about the end of November, I observed that the food in its repository was all consumed, except about half-a-dozen grains." 


\section{THE RAT.}

IF a word may be said for the little sleek and timid mouse, it must be confessed that the rat is an unpleasant looking creature. The black rat was long the common species in this country ; but the brown one, supposed to have been introduced from the continent, but originally from India or Persia, is now met with far more frequently. There is a marked difference between these creatures : the latter, or Norway rat, as it is usually called, is fierce, and lives in little harmony even with its own species, while the black rats are sociable in their habits, and show kindness and friendship to each other.

A rat, it appears, may be sociable also with other creatures. A gentleman, for instance, travelling through Mecklenburg, observed in a post-house a singular circumstance. After dinner, the landlord having placed on the floor a large dish of soup, gave a loud whistle, and immediately there came into the room a mastiff, a 


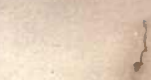

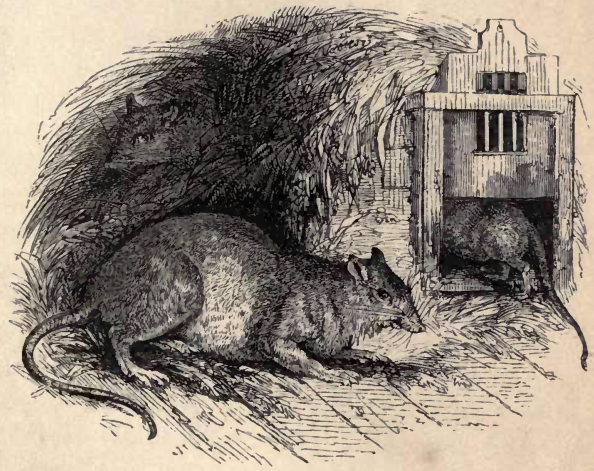

THE RAT. 
fine Angola cat, an old raven, and a remarkably large rat with a bell about its neck. All four went to the dish, and, without disturbing each other, fed together; after which the dog, eat, and rat lay before the fire, while the raven hopped about the room. The landlord, after accounting for the animal's being so familiar, said that the rat was the most useful of the four; for the noise he made had completely freed the house from the rats and mice with which it was before infested.

Persons accustomed to pass over the Southwark and Waterloo Bridges must have often observed a still more remarkable association. A man, named Austin, has exhibited there alternately, for many years past, a large number of animals, among which are cats, mice, rats, hawks, and sparrows, all living together in the most amicable manner. He states that the cause of this concord is in their being bred together; and as they are all so well fed, their predatory habits appear to be counteracted.

As the writer stopped to look at this singular collection, and to converse with the owner a short time since, he observed an instance of feline docility. Austin opened the door, and called a fine large cat, who immediately came out, and, at the word of command, took her station on the top of the cage. On another charge 
being given, she laid her head very quietly down on one of its sides; but, as she did not do this so completely as she could, she put it quite down when again told to do so. A small piece of meat was then given as the reward of her obedience, and she entered her dwelling directly she was told. This cat at one time suckled three rats. Since the time now referred to, the attention of the writer was directed to a cat in the same exhibition, engaged with her kittens. A rat was at this time in a small box a little above them, when Austin told him he would find a warmer place among the kittens, and in a moment he descended from his place, and tried the experiment, without any of the party appearing in the slightest degree disconcerted.

It would seem that there is, in the case of Austin's animals, not only association, but attachment. The birds, it is said, being set at liberty, soon return to their companions, though among these appear the cat, the hawk, and the owl! But, it is a curious fact, that when animals cannot associate with their own species, they form companionships of a very singular character. The author of "The Menageries," for instance, states the following circumstance:- "We were lately visiting in a house, where a very pleasing and singular portrait attracted our observation : it was that of a young lady, 
represented with a partridge perched upon her shoulder, and a dog with his feet on her arm. We recognised it as a representation of the lady of the house, but were at a loss to account for the odd association of her companions. She observed our surprise, and at once gave the history of the bird and the spaniel. They were both, some years back, domesticated in her family. The dog was an old parlour favourite, who went by the name of Tom. The partridge was more recently introduced from France, and answered to the equally familiar name of Bill. It was rather a dangerous experiment to place them together; for Tom was a lively and spirited creature, very apt to torment the cats, and to bark at any object which roused his instinct. But the experiment was tried; and Bill, being very tame, did not feel much alarm at his natural enemy. They were, of course, shy at first, but this shyness gradually wore off : the bird became less timid, and the dog less bold. The most perfect friendship was, at length, established between them. When the hour of dinner arrived, the partridge invariably flew on his mistress's shoulder, calling with a shrill note which is well known; and the spaniel leaped about with equal ardour. One dish of bread and milk was placed on the floor, out of which the spaniel and bird fed together ; and, after their sound 
meal, the dog would retire to a corner to sleep, while the partridge would nestle between his legs, and never stir till his favourite awoke. Whenever the dog accompanied his mistress out, the bird displayed the utmost disquietude till his return; and once, when the partridge was shut up by accident during a whole day, the dog searched about with a mournful cry, which indicated the strength of his affection. The friendship of Tom and Bill was, at length, fatally terminated. The beautiful little dog was stolen; and the bird from that time refused all food, and died on the seventh day, a victim to its grief."

To return to the rat: a singular instance of the sagacity of one of these creatures is said to have occurred in the neighbourhood of Haddington, during a dreadful storm in September, 1829. At the time the river Tyne was at its height, a number of people were standing on its margin, watching the quantities of hay which it was sweeping along. In the midst of the huge masses that were observed, a swan appeared, sometimes struggling for the land, and at others sailing majestically along with the torrent. As this noble bird approached, a black spot appeared on its snowy plumage, and much surprise was excited on finding that this black spot was a live rat. There was reason to think it had 
been borne from its dwelling in some hay-rick; and, observing the swan, had sought a refuge in its plumage. No sooner had the latter reached the land, than the rat leaped from its back, and scampered off; but, though spared by the tempest, it was speedily killed by a blow from a staff.

It appears that there are circumstances which lead to the occasional confidence of animals in others, generally regarded as their natural enemies. Of this, the following is a curious illustration. A gentleman, who lived some years since in the village of Ickleton, in Cambridgeshire, was accustomed, after his shooting excursions, to feed his dogs in their kennels, the food being placed in a long trough. On one occasion, when he had attended to them personally, as usual, he looked into the kennel through a hole in the door ; and was somewhat astonished, not at perceiving a number of rats there, but at seeing them in the trough, quietly and fearlessly partaking of bread and milk with the dogs, which seemed to pay no attention to them whatever. He was determined to destroy the rats; and, the next day, placed the trough in such a position, that a gun pointed through the hole would rake it from one end to the other. At the usual hour, the food was placed as a lure, and the dogs were kept out; but the plan 
did not succeed. The plotter against the rats could observe the head of one of them, old and sagacious, peering out at hole after hole, and from under the manger, for the purpose of reconnoitring, but none of them descended. Having waited half an hour to no purpose, he let in the dogs, and in a few moments they were again feeding in perfect harmony. Had he not ascertained this, he might have supposed that altering the position of the trough, or some other trifling alteration, had aroused the suspicion of the rats; but now they seemed to be aware that their safety was connected with the presence of the dogs.

The instances of animal sagacity, so freely interspersed with the brief account of British Quadrupeds, now reaching its conclusion, cannot have failed to awaken in the bosoms of many readers, wonder, admiration, and delight. It should, however, be remarked, that a narrow limit, after all, has been assigned to instinct; while far beyond its range we can go, because "there is a spirit in man, and the inspiration of the Almighty giveth him understanding." How amazing are the faculties of the human soul!-all admirably adapted to each other, so that each is essential to the perfection of the rest. Were but one wanting, the other powers could not discharge their functions; dis- 
order, imperfection, and weakness would appear. And hence all are present, and wondrously balanced, to secure the ends which God contemplated when he breathed into the nostrils of Adam the "breath of life, and man became a living soul."

And what are these ends? They appear in knowing, enjoying, and glorifying the great, all-wise, and benevolent Author of our being. The Gospel comes to us, containing an ample revelation of his character and designs, the offers of his mercy, and exceeding great and precious promises to all who accept his invitations. Here is the great instrument through which alone we can become partakers of that knowledge which is life eternal. When this is our character, we shall have communion with the Father, and fellowship with his Son Jesus Christ ; all our powers will be devoted to his honour, and the service now rendered shall be the earnest of that which is productive of unspeakable happiness before the throne of God and of the Lamb. It behoves us, therefore, while pursuing human knowledge, to consider the knowledge that is divine and supremely important, and that this can only be possessed as we promptly and gratefully receive "the glorious gospel of the blessed God."

"Thus saith the Lord, Let not the wise man glory 
in his wisdom, neither let the mighty man glory in his might, let not the rich man glory in his riches: but let him that glorieth glory in this, that he understandeth and knoweth me, that I am the Lord which exercise loving-kindness, judgment, and righteousness, in the earth : for in these things I delight, saith the Lord," Jer. ix. 23, 24. And what is the language of the Divine Redeemer? "This is life eternal, that they might know thee the only true God, and Jesus Christ whom thou hast sent," John xvii. 3 .

THE END. 


\section{THE RELIGIOUS TRACT SOCIETY.}

\section{SCRIPTURE NATURAL HISTORY.}

Containing a Description of Quadrupeds, Birds, Reptiles, Amphibia, Fishes, etc., mentioned in the Holy Scriptures.

Illustrated with numerous Engravings.

Royal 18mo., $3 s$. boards; $4 s$. extra boards, gilt edges.

\section{BRITISH BIRDS.}

Embellished with superior Engravings.

$16 \mathrm{mo}$. square, $3 s .6 d$. elegantly bound in cloth, gilt edge

\section{THE HISTORY OF INSECTS.}

Embellished with numerous Engravings. $16 \mathrm{mo}$. square, $3 s .6 d$. elegantly bound in cloth, gilt edges.

\section{SHELLS AND THEIR INMATES.}

Illustrated with numerous Engravings and a Frontispiece in oil colours. $16 \mathrm{mo}$. square, $3 s .6 d$. elegantly bound in cloth, gilt edges.

\section{LIGHT ;}

ITS PROPERTIES AND EFFECTS.

Embellished with numerous Engravings.

$16 \mathrm{mo}$. square, $3 s .6 d$. elegantly bound in cloth, gilt edges.

\section{ELECTRICITY ;}

ITS PHENOMENA, LAWS, AND RESULTS.

Illustrated with numerous Engravings.

$16 \mathrm{mo}$. square, $3 s .6 d$. elegantly bound in cloth, gilt edges. 
Published by the Religious Tract Society.

\section{HEAT;}

ITS SOURCES, INFLUENCES, AND RESULTS.

Illustrated with numerous Engravings.

$16 \mathrm{mo}$. square, 3s. $6 d$. elegantly bound in cloth, gilt edges.

\section{A POPULAR \\ INTRODUCTION TO THE STUDY OF BIRDS;}

OR, THE RLEMENTS OF ORNITHOLOGY, ON SCIENTIFIC PRINCIPLES ; WITH A PARTICULAR NOTICE OF THE BIRDS MENTIONED IN SCRIPTURE.

With Two Hundred superior Engravings.

Royal 18mo., $8 s$. boards; $10 s$. half-bound; $12 s$. calf extra.

A POPULAR

INTRODUCTION TO THE STUDY OF QUADRUPEDS;

OR, OF THE CLASS MAMMALIA, ON SCIENTIFIC PRINCIPLES; ADAPTED FOR YOUTH.

With a particular Notice of those mentioned in Scripture.

Illustrated with about One Hundred superior Engravings. Royal $18 \mathrm{mo} ., 6 s$. boards ; 8 s. half-bound morocco; $9 s .6 d$. calf extra.

\section{A POPULAR \\ HISTORY OF REPTILES;}

OR, AN INTRODUCTION TO THE STUDY OF THE CLASS REPTILIA.

Illustrated with numerous superior Engravings.

Royal $18 \mathrm{mo} .6 \mathrm{~s}$. boards ; $8 \mathrm{~s}$. half-bound, moroceo, gilt edges; 9 s. $6 d$. calf extra. 


\section{Published by the Religious Tract Society.}

BIRDS.

Containing The Nest, The Egg, The Feather, The Song-Bird, Instinct of Birds. 16mo. square, $2 s$, cloth boards.

\section{PLANTS.}

Containing The Seed, The Leaf, The Flower, The Fruit, The Grass. $16 \mathrm{mo}$. square, $2 s$. cloth boards.

REMARKABLE INSECTS.

Containing The Honey Bee, The Fly, The Ant, The Spider, The Gall Insect. $16 \mathrm{mo}$. square, $2 s$. cloth boards.

\section{THE SENSES.}

Containing The Eye, The Tongue, The Hand, The Ear, The Sense of Smell. J6mo. square, $2 s$. cloth boards.

\section{WONDERS OF THE WATERS.}

Containing The Animalcule, The Coral-Maker, The Sea-Star, The Lobster, The Fish. $16 \mathrm{mo}$. square, $2 s$. cloth boards. 
Published by the Religious Tract Society.

MISSIONARY RECORDS.

INDIA.

2s. $6 d$. boards ; $3 s .6 d$. half-bound.

CHINA, BURMAH, CEYLON, ETC.

With a Map.

2s. 6d. boards ; 3s. $6 d$. half-bound.

NORTH AMERICA.

2s. $6 d$. boards ; $3 s .6 d$. half-bound.

NORTHERN COUNTRIES.

With a Map.

2s. $6 d$. boards ; $3 s .6 d$. half-bound.

SANDWICH ISLANDS.

With a Map.

2s. $6 d$. boards ; 3s. $6 d$. half-bound.

TAHITI AND THE SOCIETY ISLANDS.

With a Map.

$2 s .6 d$. boards; $3 s .6 d$. half-bound.

WEST AFRICA.

With a Map.

2s. $6 d$. boards; $3 s .6 d$. half-bound.

WEST INDIES.

With a Map.

$2 s .6 d$. boards ; $3 s .6 d$. half-bound.

MISSIONARY BOOK FOR THE YOUNG.

A First Book on Missions.

With Embellishments.

1s. cloth; $2 s$. elegantly half-bound morocco, gilt edges. 


\section{Published by the Religious Tract Society.}

\section{MEMOIR OF THE REV. HENRY MOWES,}

Late Pastor of Altenhausen and Ivenrode, in Prussia.

Principally translated from the German.

With an Introduction by the Rev. John Davies, B.D., Rector of Gateshead.

$18 \mathrm{mo} ., \mathrm{ls} .6 d$. cloth boards; $2 s$. half-bound.

\section{LIVES OF THE BRITISH REFORMERS;}

FROM WICKLIFFE TO FOX.

18mo. Edition, $3 s$. boards; $4 s$, half-bound. Royal Edition, with Twelve Portraits, $6 s$. boards ; $9 s$. calf.

LIFE OF THE REV. CHRISTIAN GOTTFRIED ASSMANN, Successively Pastor of Dolzig, Gartz, and Hagen. From the German.

Written by Himself; with a Preface by the Rev. C. B. Tayler, M.A. 1s. $6 d$. boards ; $2 s .6 d$. half-bound.

\section{LIFE OF WILLIAM FAREL, \\ The Swiss Reformer.}

From the German of the Rev. M. Kirchhofer, of Stein on the Rhine. $3 s$. boards ; $4 s$. half-bound.

LIFE OF THE REV. F. A. A. GONTHIER, Minister of the Gospel at Nimes, and in Switzerland. From the French of his Nephews, L. and C. Vulliemin. With a Preface by the Rev. C. B. Tayler, M.A. $2 s .6 d$. boards; $3 s .6 d$. half-bound.

\section{LIFE OF CYPRIAN.}

18mo., ls. cloth, gilt edges.

\section{LIFE OF ORIGEN.}

18mo., Is. cloth, gilt edges. 
Published by the Religious Tract Society.

\section{LIFE OF FELIX NEFF,}

Pastor of the High Alps.

$2 s$. boards; $3 s$. half-bound, or silk, or roan; $5 s$. calf.

\section{MEMOIR OF HARLAN PAGE;}

or, The Power of Prayer and Personal Exertion for the Souls of Individuals.

By the Rev. W. Hallock.

1s. $6 d$. boards ; 2 s. half-bound; $4 s$. calf.

MEMOIR OF THE ILLNESS AND DEATH OF WILLIAM T. BUCHANAN, Es\&,

Of Ifracombe, Devon.

By the late W. Shepherd, Esq.

1s. $6 d$. boards; $2 s .6 d$. half-bound.

A MOTHER'S JOURNAL,

During the Last Illness of her Daughter, Sarah Chisman.

With a Preface by Jane Taylor.

Fifth Edition, royal 32mo., 1s. $4 d$. boards; $2 s .6 d$. roan, or silk; 3s. $6 d$. calf.

MEMOIR OF MARY MERCY ELLIS,

Wife of the Rev. William Ellis, Missionary to the South Seas. $18 \mathrm{mo} ., 1 s .6 d$. boards ; $2 s$. half-bound.

\section{MEMOIR OF MRS. HARRIET WINSLOW;}

Including a Sketch of the Ceylon Mission. By Miron Winslow, one of the Missionaries.

With an Introduction by James H. Evans. 2s. $6 d$. boards ; 3 s. $6 d$. half-bound; $5 s .6 d$. calf.

MEMOIR OF MRS. SARAH LANMAN SMITH,

Late of the American Mission in Syria.

By Edward W. Hooker, of Bennington, Vermont. 1s. $6 d$. boards; $2 s$. half-bound; $2 s .6 d$. silk, or roan ; $4 s$. calf. 
, 

IBRARY.OF

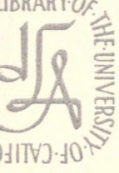

CALIFORN/\%.

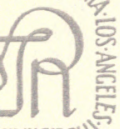

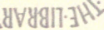

SS.ANCELES.,

IJNINA-3HI

OS.ANGELES:>

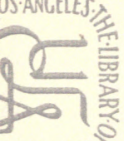

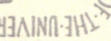

\section{This book is DUE on the last date stamped below}

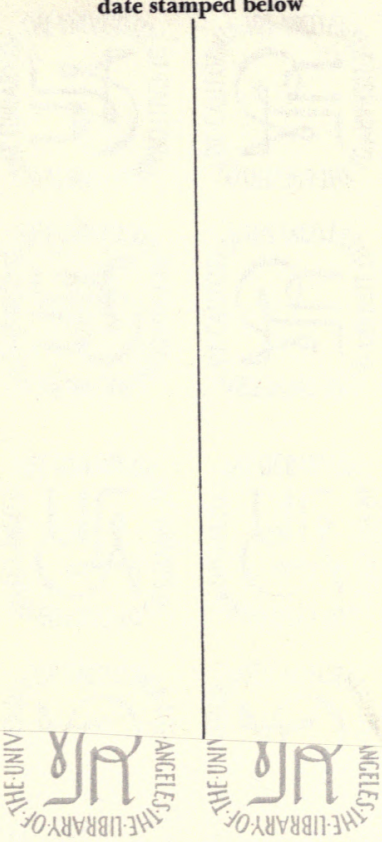

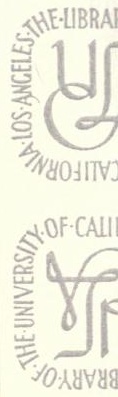

THE-UNIV
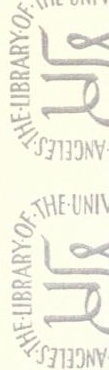

